INTERNATIONAL MONETARY FUND

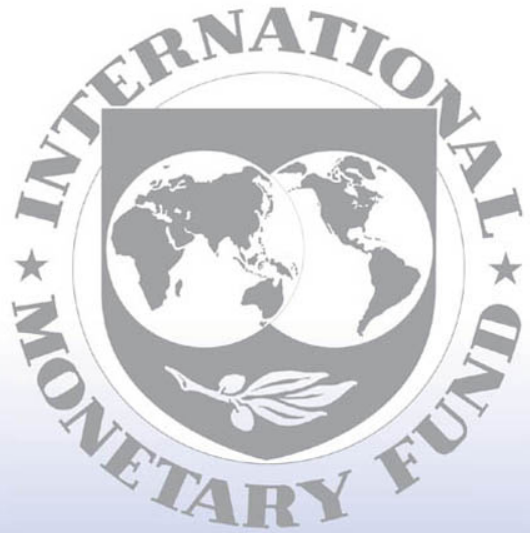

Staff

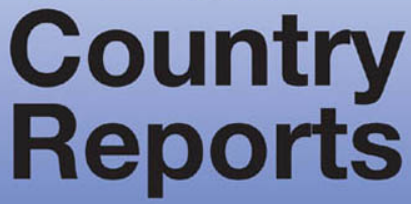




\section{Democratic Republic of the Congo: Enhanced Initiative for Heavily Indebted Poor Countries-Completion Point Document and Multilateral Debt Relief Initiative Paper}

This paper was prepared by staff of the International Monetary Fund and the World Bank in connection with Executive Board's consideration of the Democratic Republic of the Congo's completion point under the enhanced Initiative for Heavily Indebted Poor Countries and debt relief under the Multilateral Debt Relief Initiative. It is based on the information available at the time it was completed on June 15, 2010. The views expressed in this document are those of the staff team and do not necessarily reflect the views of the government of the Democratic Republic of the Congo or the Executive Board of the IMF.

The policy of publication of staff reports and other documents by the IMF allows for the deletion of market-sensitive information.

Copies of this report are available to the public from

International Monetary Fund $\bullet$ Publication Services $70019^{\text {th }}$ Street, N.W. $\bullet$ Washington, D.C. 20431

Telephone: (202) 623-7430 • Telefax: (202) 623-7201

E-mail: publications@imf.org Internet: http://www.imf.org

\section{International Monetary Fund Washington, D.C.}




\section{THE INTERNATIONAL MONETARY FUND AND \\ THE INTERNATIONAL DEVELOPMENT ASSOCIATION \\ DEMOCRATIC REPUBLIC OF THE CONGO}

\section{Enhanced Heavily Indebted Poor Countries Initiative \\ Completion Point Document and \\ Multilateral Debt Relief Initiative}

\section{Prepared by the Staffs of the International Monetary Fund (IMF) \\ and the International Development Association (IDA) \\ Approved by Mark Plant and Christian Mumssen (IMF) \\ Obiageli K. Ezekwesili and Otaviano Canuto (IDA)}

June 15,2010

Contents

Acronyms

Executive Summary .$\underline{4}$

I. Introduction $\underline{6}$

II. Assessment of Requirements for Reaching the Completion Point ................................ $\underline{6}$

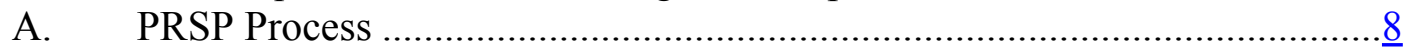

B. Macroeconomic Stability ….............................................................11

C. Use of Budgetary Savings …………….................................................

D. Public Expenditure Management .............................................................

E. Governance and Service Delivery in Priority Sectors ................................17

F. Social and Rural Sector Strategies .........................................................

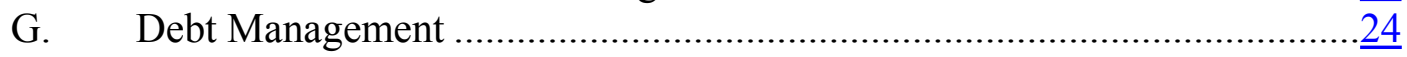

III. Updated Debt Relief and Debt Sustainability Analysis..........................................25

A. Revision of HIPC Assistance and Status of Creditor Participation...............27

B. Considerations for Exceptional Topping-Up Assistance ............................

C. Creditor Participation in the MDRI......................................................

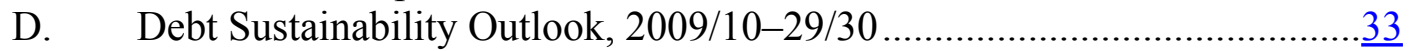

E. Sensitivity Analysis and Long-Term Debt Sustainability ............................

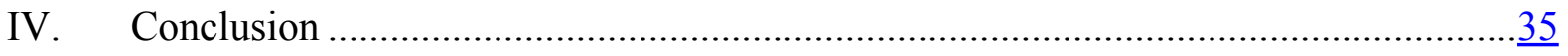

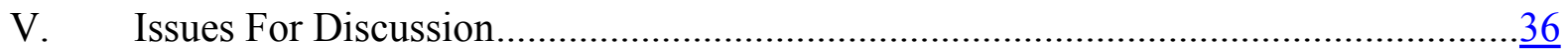


Boxes

1. Status of Floating Completion Point Triggers

2. The Treatment of Claims held by Belgolaise Bank ....................................................

3. Key Baseline Macroeconomic Assumptions ……….............................................

Figures

1. Composition of the Stock of External Debt by Creditor Group ……….........................

2. External Debt and Debt Service Indicators for Medium-and Long-Term

Public Sector Debt, 2010-30 ............................................................................

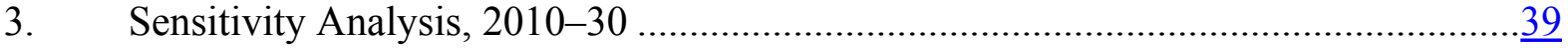

Tables

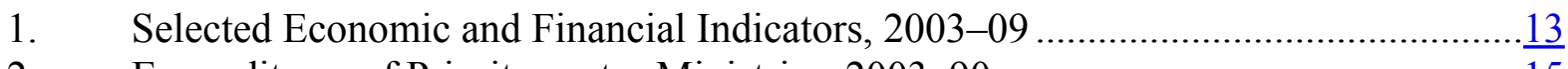

2. Expenditures of Priority-sector Ministries, 2003-90 ...............................................

3. Breakdown of the Increase of NPV of Debt-to-Exports Ratio .....................................

4. Revised Nominal Stocks and Net Present Value of Debt at Decision Point

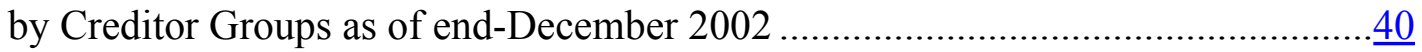

5. Estimated Assistance at Decision Point (Amended) ...................................................41

6. Comparison of Discount Rate and Exchange Rate Assumptions ................................

7. Status of Creditor Participation Under the Enhanced HIPC Initiative .........................43

8. Nominal and Net Present Value of External Debt Outstanding

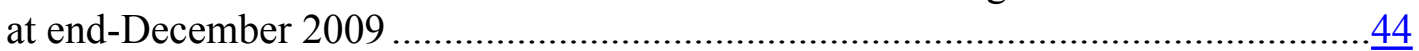

9. Present Value of External Debt..................................................................

10. External Debt Service after Full Implementation of Debt-Relief Mechanisms............ 46

11. Key External Debt Indicators, 2009-30 ……................................................

12. Sensitivity Analysis, 2009-30 .....................................................................

13. Delivery of IMF Assistance under the Enhanced HIPC Initiative and the MDRI, 2003-15

14. Delivery of IDA Assistance under the Enhanced HIPC Initiative and the MDRI, 2010-44 ......................................................................................

15. Paris Club Creditors' Delivery of Debt Relief Under Bilateral Initiatives Beyond the HIPC Initiative.

16. HIPC Initiative: Status of Country Cases under the Initiative .$\underline{51}$

.

Appendices

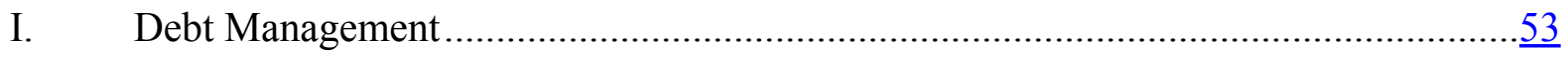

II. Debt Sustainability Analysis using the Low-Income Country Framework ...................55 


\section{ACRONYMS}

\begin{tabular}{|c|c|}
\hline AfDB & African Development Bank \\
\hline AfDF & Africa Development Fund \\
\hline AFRITAC & African Regional Technical Assistance Center \\
\hline AGRER & Agrer Etudes et Conseils \\
\hline ARMP & Agence de Regulation des Marchés Publics (Public Procurement Regulatory Authority) \\
\hline BERCI & Bureau d'Études, de Recherches et Consulting International \\
\hline BGDEL & Banque de Développement des Etats des Grands Lacs \\
\hline CEMAC & $\begin{array}{l}\text { Communauté Économique Monétaire de l'Afrique Centrale } \\
\text { (Central African Economic and Monetary Community) }\end{array}$ \\
\hline CFAA & Country Financial Accountability Assessment \\
\hline CAD & Chart of Accounts \\
\hline DGMP & Public Procurement General Directorate \\
\hline DGDP & Direction Generale de la Dette Publique \\
\hline DMFAS & Debt Management and Financial Analysis System \\
\hline DRC & Democratic Republic of the Congo \\
\hline DSA & Debt Sustainability Analysis \\
\hline EC & European Commission \\
\hline ECF & Extended Credit Facility \\
\hline EITI & Extractive Industries Transparency Initiative \\
\hline ESB & Etats de Suivis Budgetaires \\
\hline EU & European Union \\
\hline GDP & Gross Domestic Product \\
\hline GIBS & Groupe Inter-Bailleurs de la Sante \\
\hline HIPC & Heavily Indebted Poor Countries \\
\hline HIV/AIDS & Human Immunodeficiency Virus/Acquired Immunodeficiency Syndrome \\
\hline IDA & International Development Association \\
\hline IMF & International Monetary Fund \\
\hline JSAN & Joint Staff Advisory Note \\
\hline LICUS & Low Income Countries under Stress \\
\hline MDGs & Millennium Development Goals \\
\hline MDRI & Multilateral Debt Relief Initiative \\
\hline MOF & Ministry of Finance \\
\hline NGO & Non-Governmental Organization \\
\hline NHDP & National Health Development Plan \\
\hline NHSS & National Health Sector Strategy \\
\hline PETS & Public Expenditure Tracking Survey \\
\hline PFM & Public Financial Management \\
\hline PR & Progress Report \\
\hline PRCG & Projet de Renforcement de Capacité et de Gouvernance \\
\hline PRS & Poverty Reduction Strategy \\
\hline PRSP & Poverty Reduction Strategy Paper \\
\hline PRGS & Poverty Reduction and Growth Strategy \\
\hline PUAICF & Projet dÚrgence dÁttenuation des Impacts de la Crise Financiere \\
\hline PV & Present Value \\
\hline SCCA & Sino-Congolese Cooperation Agreement \\
\hline SDR & Special Drawing Right \\
\hline UN & United Nations \\
\hline UNDP & United Nations Development Program \\
\hline WBI & World Bank Institute \\
\hline
\end{tabular}




\section{EXECUTIVE SUMMARY}

In July 2003, the Boards of Executive Directors of the International Monetary Fund (IMF) and the International Development Association (IDA) agreed that the Democratic Republic of Congo (DRC) had met the requirements for reaching the decision point under the enhanced Heavily Indebted Poor Countries (HIPC) Initiative. To reduce the present value (PV) of eligible external debt to 150 percent of exports, the amount of debt relief determined at the decision point was US\$6,311 million at end-December 2002, in PV terms. This relief implied a common reduction factor of 80.2 percent.

- The DRC has successfully implemented key reforms under the enhanced HIPC Initiative, despite experiencing exceptional challenges since the decision point, including a challenging security situation. IMF and IDA staffs are of the view that the DRC has made satisfactory progress in meeting the requirements to reach the completion point. All completion point triggers have been fully implemented. The first poverty reduction strategy paper (PRSP) was finalized in 2006 and formally adopted in 2007. Its implementation has been satisfactory, as acknowledged by the Joint Staff Advisory Note (JSAN) on the Progress Report (PR) of the DRC Poverty Reduction and Growth Strategy (PRGS). The First Review under the Extended Credit Facility (ECF) arrangement is being completed concurrently with the HIPC completion point review. In addition, the authorities have fully implemented the triggers on the use of HIPC resources for pro-poor spending, improvement in public expenditure management, improvement in governance and procurement, enhancements in service delivery in priority sectors, and public debt management.

As a result of the debt reconciliation exercise for the completion point, the PV of eligible external debt at December 31, 2002, after traditional debt relief has been revised upward by US\$933 million. Therefore, the required HIPC assistance at December 31, 2002, in PV terms has been revised from US\$6,311 million at the decision point to US\$7,252 million. The common reduction factor has increased from 80.2 percent to 82.4 percent.

- Creditors accounting for approximately 96 percent of the revised PV of HIPC assistance have given satisfactory assurances of their participation in the enhanced HIPC Initiative. All multilateral creditors with two exceptions, ${ }^{1}$ all Paris

\footnotetext{
${ }^{1}$ The Banque de Development des Etats des Grand Lacs (BDEGL) and the Banque des Etats de l'Afrique Centrale (BEAC) have not officially agreed to participate. BDEGL is currently in negotiations with the authorities on providing debt relief. BEAC has provided debt relief amounting to $\$ 2.8$ million in PV terms at the decision point resulting from multiple rounds of arrears rescheduling (see footnote 20).
} 
Club creditors, and some other official creditors, have agreed to participate. The authorities are working toward securing the participation of the remaining creditors.

- The DRC does not qualify for topping-up under the enhanced HIPC Initiative. The ratio of PV of debt-to-exports after enhanced HIPC assistance at end-December 2009, was 44.2 percent, substantially lower than anticipated at the decision point. This decrease is the result of higher-than-expected exports and lowerthan-expected new borrowing. The ratio of PV of debt-to-exports at end-December 2009, and after the full delivery of additional bilateral debt relief beyond the HIPC Initiative, is estimated to be 43.3 percent, well below the 150 percent threshold for topping-up consideration under the enhanced HIPC Initiative.

- Upon reaching the completion point under the enhanced HIPC Initiative, the DRC will also qualify for additional debt relief under the Multilateral Debt Relief Initiative (MDRI), beyond-HIPC assistance from the Paris Club, and the Least Developed Country (LDC) Initiative from the European Union (EU). Debt relief under the MDRI from IDA would reduce nominal debt service by an average of US\$28.4 million per year until 2043.

- Full delivery of HIPC debt relief, additional bilateral assistance beyond HIPC and MDRI debt relief at the completion point would reduce the DRC's external debt burden significantly. The ratio of PV of debt-to-exports at end-December 2010 would fall to 57.5 percent after delivery of MDRI assistance; this ratio is predicted to increase until end December 2013 mainly due to new borrowing, and thereafter is expected to decrease to 31.1 percent by end-December 2030. However, the future evolution of these indicators is highly uncertain and will depend on several factors, particularly economic growth and the terms of new external financing. approve the completion point for the DRC under the enhanced HIPC Initiative. 


\section{INTRODUCTION}

1. This paper discusses the DRC's progress under the enhanced HIPC Initiative. In the view of the staffs of the IMF and the IDA, this progress is sufficient for recommending to their respective Boards of Executive Directors the approval of the completion point for the DRC under the enhanced HIPC Initiative. The authorities have fully implemented all the completion point triggers as formulated in the 2003 HIPC Decision Point document. ${ }^{2}$

\section{In July 2003, the Boards of Executive Directors of the IMF and the IDA agreed} that the DRC had met the requirements for reaching the HIPC decision point. Executive Directors also determined that the floating completion point would be reached when the triggers in Box 6 of the Decision Point Document were met. The amount of debt relief committed at the decision point was US\$ 6,311 million in PV terms, calculated as of end-December 2002. Such relief represented an overall reduction of 80.2 percent in the PV of all public-and publicly-guaranteed external debt as of end-December 2002 after application of traditional debt relief mechanisms. At the same time, the two Boards approved interim debt relief to the DRC. IMF interim relief was suspended from June 2006 to December 2009 because the DRC was not supported under a formal IMF arrangement. The DRC reached the ceiling for HIPC interim relief provided by the IDA of 33 percent of committed debt relief (in PV terms) on October 15, 2009. Interim relief resumed on December 15, 2009, when the IDA ceiling was raised to 50 percent. $^{3}$

3. This paper is organized as follows. Section II assesses the DRC's performance in meeting the requirements for reaching the completion point under the enhanced HIPC Initiative. Section III provides an updated debt relief and debt sustainability analysis (DSA), including the status of creditor participation, and delivery of debt relief under the HIPC Initiative and the MDRI. Section IV summarizes the main conclusions, and Section V presents issues for discussion by Executive Directors.

\section{ASSESSMENT OF REQUIREMENTS FOR REACHING THE COMPLETION PoInT}

\section{In the view of the staffs of the IMF and the IDA, the DRC has met in full all the} triggers for reaching the completion point (see Box 1). All key decisions, actions, and measures required to fulfill the triggers have been taken, including progress in the implementation of the PRS (Trigger 1); maintenance of a sound macroeconomic program, as indicated by performance under the program supported by the ECF arrangement (Trigger 2); satisfactory use of HIPC resources for pro-poor spending (Trigger 3); improvement in public expenditure management (Trigger 4); improvement in governance and procurement (Trigger 5); enhancements in service delivery in priority sectors (Trigger 6); and in public debt management (Trigger 7).

\footnotetext{
${ }^{2}$ See "The Democratic Republic of Congo: Enhanced Initiative for Heavily Indebted Poor Country - Decision Point Document", IDA/R2003-0059/2 and IMF Country Report No. 03/267.

${ }^{3}$ The Democratic Republic of Congo: Revised Schedule of IDA's HIPC Debt Relief, IDA/SecM2009-0671, December 10, 2009.
} 
Box 1: Democratic Republic of the Congo: Status of Floating Completion Point Triggers

Trigger
1. PRSP
Completion of a full PRSP through a participatory
process and its implementation for one year, duly
documented in the DRC's annual progress reports
and confirmed as satisfactory by a JSAN.

and confirmed as satisfactory by a JSAN.

\section{Status/Comments}

Implemented. The JSAN confirmed

satisfactory preparation and implementation of the strategy. Staff also deemed overall implementation of the PRGS during the 12 months leading up to the completion point as satisfactory, with high budget execution rates and budgetary allocations for priority spending, good initial results on social outcomes, and significant progress on structural reforms.

\section{Macroeconomic stability}

Continued maintenance of macroeconomic stability after reaching the decision point, as shown by satisfactory performance under the IMF's ECFsupported program.

\section{Use of budgetary savings}

Use of budgetary savings resulting from enhanced HIPC Initiative-related debt service relief during the interim period for poverty-related expenditures in accordance with the I-PRSP, with supporting documentation.

\section{Public expenditure management}

(a) Implementation of a modernized budgetexecution system, providing information from commitment to payment, and allowing for the monitoring of arrears;

(b) Adoption and implementation of a double-entry government accounting system and a new chart of accounts; and

(c) Production of quarterly budget execution reports using economic, administrative, and functional classifications.

\section{Implemented. The staff report for the First} ECF Review was circulated to the IMF Executive Board concurrently with the HIPC document on June 14, 2010.

Implemented. HIPC resources have been allocated to key areas with greatest impact on poverty, e.g., social sectors and security.
Implemented. New modern budget-execution system covering the four key stages of expenditure management in use since 2008 at the Chaine de la Depense unit of MOF.

Implemented. Double-entry government accounting system and new chart of accounts was adopted. These have been used for budget execution since 2008 .

Implemented. Budget execution reports called ESBs have been produced quarterly since 2008 using the three most widespread international classifications. These reports also provide the status of budget arrears monthly.

\section{Governance and service delivery in priority sectors}

(a) Completion of a budget-tracking exercise on health, education, rural development and infrastructure expenditure, consisting of (i) monitoring the execution of poverty-related public expenditure; (ii) evaluation by user groups of the quality of related public services; and (iii) evaluation by service-providers of constraints to effective provision; and 
Box 1: Democratic Republic of the Congo: Status of Floating Completion Point Triggers (concluded)

\begin{tabular}{|c|c|}
\hline Trigger & Status/Comments \\
\hline $\begin{array}{l}\text { (b) Adoption and implementation of a new } \\
\text { procurement code and key implementing decrees. }\end{array}$ & $\begin{array}{l}\text { Implemented. New procurement code passed } \\
\text { by Parliament in April } 2010 \text { and all key } \\
\text { implementing steps and documents adopted } \\
\text { including the establishment of key institutions } \\
\text { and the adoption of a manual of procedures. } \\
\text { An implementation report will be prepared by } \\
\text { November } 2010 \text {. }\end{array}$ \\
\hline Social and rural sectors & \\
\hline $\begin{array}{l}\text { Adoption of satisfactory sectoral development } \\
\text { strategies and related implementation plans for } \\
\text { health, education and rural development. }\end{array}$ & $\begin{array}{l}\text { Implemented. The government adopted in } \\
2010 \text { satisfactory development strategies and } \\
\text { related action plans for all three sectors, which } \\
\text { were developed on the basis of reliable } \\
\text { analyses and consultations with stakeholders. }\end{array}$ \\
\hline Debt management & \\
\hline $\begin{array}{l}\text { Installation and full activation of a computerized } \\
\text { debt-recording system, covering all public and } \\
\text { publicly guaranteed debt, as well as public enterprise } \\
\text { debt not carrying the guarantee of the State that can: } \\
\text { (a) produce monthly debt-service projections, and } \\
\text { incorporate actual disbursement and debt-service } \\
\text { payment execution data; and } \\
\text { (b) support the centralization of debt information in } \\
\text { a single center. } \\
\text { In addition, monthly debt-service projections will be } \\
\text { published in advance on a quarterly basis. }\end{array}$ & $\begin{array}{l}\text { Implemented. Computerized debt-recording } \\
\text { system covering all the various types of public } \\
\text { debt installed and fully activated. Monthly } \\
\text { debt-service statements, including debt- } \\
\text { service projections, produced on a quarterly } \\
\text { basis and sent to the MOF for payments. All } \\
\text { debt information is now centralized at the } \\
\text { OGEDEP. }\end{array}$ \\
\hline
\end{tabular}

\section{A. PRSP Process}

Completion of a full PRSP through a participatory process and its implementation for one year, duly documented in the DRC's annual progress reports and confirmed as satisfactory by a JSAN.

\section{Staffs consider this trigger met since implementation of the full participatory}

\section{PRSP adopted in July 2006 was satisfactory, as discussed in the JSAN on the most} recent PR on the authorities PRGS. ${ }^{4}$ Since the 2002 peace process that ended full scale armed conflicts and led the country to democratic elections, the Congolese authorities have made important progress in promoting growth and fighting poverty. The 2006 PRGS has been the central reference document in guiding and designing all government programs, including the "Programme de Gouvernance", the "Cinq Chantiers". Indeed, the PRGS has

\footnotetext{
${ }^{4}$ The DRC JSAN on the PRSP Report - IMF Country Report No. 10/327.
} 
been an important step in consolidating macroeconomic stability, strengthening economic governance, and deepening program ownership. Its main pillars are to: (1) improve governance and consolidate peace by strengthening institutions; (2) promote growth and consolidate macroeconomic stability; (3) enhance access to basic social services and reduce vulnerability; (4) combat HIV/AIDS; and (5) improve community dynamics and the social environment. $^{5}$

\section{The DRC's PRGS provided a sound basis for strengthening policies due to its} participatory approach. The strategy derives much of its strength from the broad and inclusive preparation process, which involved a series of consultations in numerous provinces with stakeholders from civil society, Non-Governmental Organizations (NGO), youth groups, labor unions, parliament, and the private sector. Moreover, focus groups and country-wide surveys were undertaken with the support of the National Institute of Statistics and ten partner non-governmental organizations. Despite the conflict in the East, these surveys and consultations covered remote and dangerous areas of North and South Kivu, Katanga, and Ituri. The process also reached out as much as possible to rebel groups and political opposition factions, to foster inclusive dialogue for peace and reconstruction, and priority setting. Provincial and sector summaries of survey results were prepared as inputs to the national PRSP to capture the diversity of this immense country and to prepare the groundwork for its eventual decentralization.

\section{The 2006 Poverty Assessment (PA), based on the 2004/05 1-2-3 survey,} significantly enhanced understanding of the causes, extent, and distribution of poverty. That PA will be updated in the run up to the second PRGS. The 1-2-3 survey was the first national household poverty survey and has provided a wide range of information on poverty and living conditions. Approximately 71 percent of Congolese lived in poverty, with higher rural (76 percent) than urban (61 percent) poverty while the provinces of Kinshasa, Maniema, Katanga, and Bas-Congo fared better than the other provinces. Households headed by women were also better-off than those led by men. The report identified the main causes of poverty as the conflicts, the fall of wage employment, decline in demand for agricultural products, malnutrition and diseases, corruption, deterioration of infrastructures, environment, and basic social services, especially in rural areas. The disruption of socioeconomic ties and institutions in communities also contributed to the poverty situation. In August 2010, the authorities will launch a new poverty assessment, which will include a second 1-2-3 survey to produce comparable household and poverty data for use in the second generation PRGS.

\footnotetext{
${ }^{5}$ The IMF and the IDA Executive Directors discussed the JSAN on the PRGS in September 2007. Staffs' main conclusions were that while the PRGS contained rich insights on poverty diagnosis, it could be enhanced by additional information on sources of livelihood of households and analyses of the productive sectors.
} 


\section{Progress since 2006 in implementing the PRGS was uneven and the authorities} decided to extend the implementation period until end-2010. A government review of the PRGS over the period April 2007-December 2008 concluded that implementation needed to be strengthened if its objectives were to be achieved. In particular, budgetary spending needed to be better aligned with government priorities and the efficiency of government interventions needed to be enhanced. The authorities therefore decided to extend the implementation period of their original PRGS to end-2010 in order to assure sufficient time to achieve its objectives and to prepare a second generation strategy. ${ }^{6}$ The joint staff's assessment presented below is based on progress in implementing the first generation PRSP during the most recent period leading up to the completion point.

\section{During the past twelve months, the overall implementation of the PRGS has} been satisfactory. Despite the impact of lingering conflict and the global financial crisis, budget execution of pro-poor spending remained at over 95 percent in 2009, and the 2010 budget ceilings accommodated higher priority spending in these sectors. The higher spending is showing good initial results in terms of rising school enrollment, improved health indicators, and greater access to infrastructure, notably through the rehabilitation of roads. With the recent improvements on the security front, the authorities were able to make significant progress in 2009-10 on the structural agenda underpinning their PRGS. They developed new sector strategies and medium-term spending plans for key sectors such as education and health. New legal frameworks for procurement and businesses (OHADA) were adopted by parliament in 2009-10, and reforms in the PFM systems were resumed with renewed vigor.

\section{The 2010 PR is candid about the need to strengthen PRGS monitoring and} evaluation in the period ahead. Staffs propose that the plan to develop a comprehensive statistical strategy, identified in the PRGS, receive greater attention to support improved monitoring in the new PRGS. While progress was made in several areas (i.e., macroeconomic stability, PFM, education, child mortality, life expectancy, HIV/AIDS, access to maternal care, and decentralization), achievements in areas such as water and sanitation, maternal nutrition, gender and environment have been more modest. Monetary poverty incidence does not seem to have deteriorated significantly despite the difficult economic and social disruptions. The analytical work, including a Diagnostic Trade Integration Study, the adoption of sector strategies in several key sectors in 2010 (see $\lceil\mid 36-43$ ), as well as the surveys of public service delivery (see $\{26-28$ ) are expected to strengthen the base for policy formulation and evaluation in the next PRSP.

\footnotetext{
${ }^{6}$ See Note Synthese Sur Le Processus DSCRP EN RDC, July 15, 2009, that accompanied the PR on the 200608 PRGS (April 2007) and attached PAP for 2009-10.
} 


\section{B. Macroeconomic Stability}

Continued maintenance of macroeconomic stability after reaching the decision point, as evidenced by satisfactory performance under the IMF's ECF-supported program.

\section{Staffs consider this trigger met, as performance under the current ECF} arrangement (July 2009-June 2012) has been satisfactory. In 2003-04, the authorities implemented — in the context of the first ECF-supported program — prudent policies that curtailed the monetization of fiscal deficits - the principal cause of macroeconomic instability — and helped reduce inflation and exchange rate pressures. ${ }^{7}$ They also made notable progress in structural reforms in the areas of revenue administration, PFM and the financial sector. However, policy implementation started to weaken in 2005 as the focus of the transitional government shifted to the 2006 national elections; and, subsequently, because of periodic flares ups of conflict in the eastern provinces and inadequate fiscal discipline. Since January 2009, the authorities improved their policies and reinvigorated structural reforms - in the context of a staff monitored program (SMP) and the current ECF-supported program - despite the adverse impact of the global financial crisis on the local economy. In particular, the government curtailed its recourse to central bank financing by bolstering revenue and improving expenditure control. It advanced structural reforms, especially in revenue administration, PFM, and the financial sector. These efforts made the economy more resilient to the global economic downturn and helped reduce macroeconomic pressures.

\section{Macroeconomic performance-albeit uneven before the onset of the current}

ECF-supported program-was satisfactory. In 2003-04, real GDP expanded by 6.2 percent per annum (some 3 percentage points higher than the population growth rate), while inflation decelerated to single digits (from 135 percent in 2001). Growth began to slow in 2006 in the lead up to the election, while inflation rose because of policy slippages. In 2009 , economic growth was curbed by the deterioration in the country's terms of trade induced by a contraction in global demand for commodity exports and the consequent retrenchment of domestic demand. Year-on-year inflation rose to 53 percent at end-year due to a sharp depreciation of the Congolese Franc against the U.S. dollar in response to the drop in export receipts and an uptick in central bank credit to the government in late 2008 to finance security-related spending. However, inflation eased to 15 percent at end-April 2010, due to prudent fiscal and monetary policies. In 2010, real GDP growth is projected at 5.4 percent supported by the recovery of the mining sector on the back of high export prices, while increased public and foreign direct investment (FDI) in mining and public infrastructure will sustain growth in the services sector.

\footnotetext{
${ }^{7}$ The IMF Executive Board approved a three-year arrangement under the ECF in July 2002.
} 


\section{The external position is weak but it improved recently thanks to increased}

balance of payment support. The current account balance shifted from a balance in 2003 to a deficit of 16 percent in 2008. Although exports were buoyant in view of a strong mining sector recovery, imports grew faster partly reflecting post-conflict reconstruction.

International reserves, which averaged about three weeks of import cover in 2003-05, shrank to one week in 2007-08 because of strong domestic demand. In 2009, despite a decline in export receipts, the current account deficit narrowed reflecting a reduction in income repatriation - mainly from mining activities - and an increase in official transfers to help mitigate the impact of the global financial crisis. International reserves rose to 7 weeks of import cover, boosted by the general and special SDR allocations, disbursements under the current ECF arrangement and the rapid access component of the Exogenous Shocks Facility, and the first tranche of the signing bonus under the SCCA. The current account deficit is expected to widen in 2010 as higher imports that are tied to major investment projects in mining and infrastructure more than offset projected increase in export receipts as these investment projects are being financed largely by FDI and development assistance. International reserves are expected to increase to 7.5 weeks of import coverage by year end.

\section{Macroeconomic policy implementation-though mixed since the decision} point-improved in 2009. Macroeconomic policy performance was satisfactory in 2003-04. Government revenue rose from 7.7 percent of GDP in 2001 to 9.5 percent in 2004 . The increase in revenue, combined with a renewal of the DRC's access to external financing, allowed the government to increase spending, including on investment, while avoiding the monetization of the fiscal deficit. This helped the central bank better control monetary aggregates in line with its disinflation objective. However, there were fiscal slippages in the lead up to the 2006 elections, and policy implementation remained uneven until end-2008. The authorities made good progress and established a track record of good macroeconomic management under the SMP. Performance improved further under the current ECF supported program. Thanks to a strong revenue effort, increased donor support, and better expenditure control, the 2009 domestic fiscal deficit (cash basis and before official transfers) was held to 2.5 percent of GDP on a cash basis, 0.6 percentage points lower than envisaged. This, along with higher external budget support helped the government build significant deposits at the central bank. The improvement in the fiscal position and an increase in the central bank's discount rate from 40 percent to 70 percent in three steps helped contain base money growth. Policy implementation in 2010 has been satisfactory thus far, and the objectives and targets for end-June of the current ECF-supported program are likely to be achieved.

\section{Structural reforms were critical to improving macroeconomic management. In}

2003-04, the authorities made notable progress. They tightened and streamlined expenditure commitment procedures, including through computerization. On the revenue side, administrative capacity to collect revenue was rebuilt and data collection and information management systems strengthened. A new large taxpayers' unit was established, monitoring of exemptions was enhanced, and customs procedures were simplified. The capacity of the central bank to conduct monetary policy and supervise commercial banks was also strengthened. Although the pace of structural reforms slowed during the period 2005-08, it 
picked up in 2009 under the current ECF-supported program. On revenue administration, the authorities further strengthened the information management systems of both the customs and tax departments, enhanced import valuation procedures, strengthened the large taxpayers unit (especially regarding collection from the mining sector), and adopted an action plan to reduce and streamline tax exemptions. On PFM, they established transparent procedures for the commitment and payment of urgent spending, improved the planning and the monitoring of expenditure commitments, and advanced reforms to modernize the legal and regulatory framework of the PFM system. The authorities also adopted an action plan setting out the strategy and the objectives for PFM reforms for the coming years. On financial sector reform, the BCC was restructured and reorganized as the first step toward its recapitalization and eventual financial independence. Banking supervision was also strengthened, as was the central bank's capacity to conduct monetary policy.

Table 1. Democratic Republic of the Congo: Selected Economic and Financial Indicators, 2003-09

\begin{tabular}{|c|c|c|c|c|c|c|c|}
\hline & 2003 & 2004 & 2005 & 2006 & 2007 & 2008 & 2009 \\
\hline & \multicolumn{7}{|c|}{ (Annual percentage change; unless otherwise indicated) } \\
\hline \multicolumn{8}{|l|}{ GDP and prices } \\
\hline Real GDP & 5.7 & 6.6 & 7.8 & 5.6 & 6.3 & 6.2 & 2.8 \\
\hline Consumer prices, period average & 12.8 & 4.0 & 21.4 & 13.2 & 16.7 & 18.0 & 46.2 \\
\hline Consumer prices, end-of-period & 4.4 & 9.2 & 21.3 & 18.2 & 10.0 & 27.6 & 53.4 \\
\hline \multicolumn{8}{|l|}{ External sector } \\
\hline Exports, f.o.b. (U.S.dollars) & 24.6 & 35.9 & 13.8 & 13.5 & 161.2 & 7.2 & -33.6 \\
\hline Imports, f.o.b. (U.S.dollars) & 18.8 & 43.3 & 40.9 & 16.9 & 81.8 & 27.6 & -26.3 \\
\hline Export volume & 4.6 & 18.5 & -5.5 & -12.5 & 55.5 & 6.3 & 0.6 \\
\hline Import volume & 10.5 & 31.7 & 32.8 & 15.0 & 69.0 & 15.8 & -17.9 \\
\hline & \multicolumn{7}{|c|}{ (Percent of GDP; unless otherwise indicated) } \\
\hline \multicolumn{8}{|l|}{ Central government finance } \\
\hline Total revenue (including grants) & 9.7 & 11.5 & 16.6 & 19.5 & 17.0 & 20.8 & 23.7 \\
\hline Of which: Domestic revenue & 7.7 & 9.5 & 11.4 & 12.8 & 14.7 & 18.5 & 16.8 \\
\hline Total expenditure & 14.9 & 15.8 & 20.5 & 20.1 & 18.9 & 23.0 & 26.7 \\
\hline Overall fiscal balance (payment order basis, incl. grants) & -5.2 & -4.3 & -3.9 & -0.6 & -1.9 & -2.2 & -3.0 \\
\hline Overall fiscal balance (cash basis, incl. grants) & -2.7 & -3.0 & -10.3 & -0.7 & -2.5 & -3.0 & -3.9 \\
\hline Domestic balance (cash basis) & -1.2 & -1.3 & -7.3 & -1.0 & -0.1 & -0.3 & -2.5 \\
\hline Gross national saving & 12.6 & 9.6 & 1.5 & 4.7 & 17.1 & 6.1 & 9.3 \\
\hline Investment & 12.2 & 12.8 & 13.8 & 13.2 & 18.2 & 22.0 & 19.4 \\
\hline \multicolumn{8}{|l|}{ Balance of payments } \\
\hline Current account balance (incl. transfers) & 0.4 & -3.2 & -12.3 & -8.5 & -1.1 & -15.9 & -10.1 \\
\hline $\begin{array}{l}\text { Gross official reserves (weeks of nonaid-related } \\
\text { imports of goods and services) }\end{array}$ & 2.8 & 3.5 & 2.4 & 1.4 & 1.2 & 0.8 & 7.2 \\
\hline
\end{tabular}

Sources: Congolese authorities and IMF staff estimates and projections. 


\section{Use of Budgetary Savings}

Use of budgetary savings resulting from enhanced HIPC Initiative-related debt service relief during the interim period for poverty-related expenditures in accordance with the I-PRSP, with supporting documentation.

16. Staffs consider this trigger met since public priority spending increased by more than the interim debt relief that was delivered since $2003 .{ }^{8}$ This is true also if, in contrast to the authorities' definition of such spending in the PRSP, security spending is excluded from priority spending. During 2003-09, the DRC received interim debt relief of US\$1,308.8 million, some US\$187 million per year while on average non-security priority spending exceeded 2003 levels by US\$250 million per year. Spending by the national authorities on agriculture, education and health sectors was extremely modest at the end of the war in 2003. ${ }^{9}$ Priority sectors, excluding security, received only 0.4 percent of GDP while security amounted to 1.7 percent of GDP. Since then, spending by the national authorities on the priority sectors (excluding security) increased to 3.5 percent of GDP. As a share of total national expenditure, these expenditures rose from 4 percent in 2003 to 18 percent in 2008 and 2009 (see Table 1). During 2006-08, the increase in non-security priority spending exceeded interim debt relief and fell to just under 100 percent in 2009 because debt relief more than doubled.

\section{The 2006 Constitution delegates responsibility for priority spending in the areas} of agriculture, education, and health to the provinces. Following an agreement between the national and the provincial authorities, public service salaries, which are by far the largest component of expenditures, continue to be administered at the national level for the period 2008-10 even though these services are now under the purview of the provincial governments. Administration of these salaries at the national level has allowed for the tracking of spending for key public services. The data on spending in Table 1 include wage and nonwage expenditures.

\section{The PFM system is sufficiently well established at the national level to monitor} the tracking of priority spending for poverty alleviation. Reports on the status of budget implementation (Etats de Suivi Budgétaire (ESB)) — albeit produced with a lag —including a functional classification of expenditures are available on a monthly basis and provide credible information on budget execution at the national level (see Section D). Weaknesses in the provincial PFM systems regarding the collection of data on priority expenditure do not impede the assessment of social sector spending at present, given that transitional

\footnotetext{
${ }^{8}$ The government started depositing interim HIPC assistance into a special Treasury account at the BCC in 2006 but discontinued the practice in 2007 as it was proving cumbersome for an already overburdened PFM system and an unnecessary duplication given the greater reliability of the newly introduced PFM system.

${ }^{9}$ Audits of these accounts at the BCC were carried out by an independent company in 2006 and 2010. Their findings were consolidated with those of the Cour des Comptes in 2010. The report reiterated the PFM weaknesses described in Section D and made recommendations to strengthen further expenditure chain management. These have been taken into account in the government's PFM reform action plan.
} 
arrangements result in most of such spending continuing to be executed at the central government level.

Table 2. Democratic Republic of the Congo: Expenditures of Priority-sector Ministries, 2003-09

\begin{tabular}{|c|c|c|c|c|c|c|c|}
\hline & 2003 & 2004 & 2005 & 2006 & 2007 & 2008 & 2009 \\
\hline \multicolumn{8}{|l|}{ In percent of GDP } \\
\hline Health & 0.1 & 0.1 & 0.5 & 0.5 & 1.0 & 0.8 & 0.6 \\
\hline Education & 0.2 & 0.2 & 1.4 & 2.0 & 2.5 & 2.8 & 2.1 \\
\hline Agriculture and Rural Development & 0.1 & 0.1 & 0.1 & 0.3 & 0.3 & 0.4 & 0.8 \\
\hline Security sectors (1) & 1.7 & 2.8 & 3.0 & 2.5 & 3.8 & 4.2 & 4.5 \\
\hline \multicolumn{8}{|l|}{ Pro memoire } \\
\hline Total, excluding security spending & 0.4 & 0.4 & 2.0 & 2.9 & 3.8 & 4.0 & 3.5 \\
\hline Total, including security spending & 2.1 & 3.2 & 5.0 & 5.4 & 7.6 & 8.2 & 8.0 \\
\hline GDP (FC, billion) & 2,299 & 2,611 & 3,431 & 4,114 & 5,148 & 6,526 & 8,729 \\
\hline \multicolumn{8}{|l|}{ In percent of total expenditures } \\
\hline Health & 1.0 & 1.0 & 3.0 & 3.2 & 5.8 & 3.9 & 3.0 \\
\hline Education & 2.3 & 1.9 & 9.3 & 11.6 & 14.3 & 13.1 & 10.8 \\
\hline Agriculture and Rural Development & 0.5 & 0.6 & 0.9 & 2.0 & 1.5 & 1.8 & 4.1 \\
\hline Police, Defence and Ministry of Interieur & 16.1 & 20.9 & 19.7 & 14.9 & 21.9 & 19.9 & 23.4 \\
\hline \multicolumn{8}{|l|}{ Pro memoire } \\
\hline Total, excluding security spending & 3.7 & 3.4 & 13.2 & 16.8 & 21.6 & 18.8 & 18.0 \\
\hline Total, including security spending & 19.9 & 24.3 & 32.9 & 31.7 & 43.5 & 38.7 & 41.3 \\
\hline Total public expenditure (FC, billion) & 242 & 345 & 520 & 699 & 904 & 1,381 & 1,700 \\
\hline \multicolumn{8}{|l|}{ In US\$ million } \\
\hline Health & 5.8 & 8.5 & 33.3 & 48.3 & 101.7 & 95.2 & 63.3 \\
\hline Education & 13.6 & 16.1 & 101.5 & 172.8 & 250.7 & 320.7 & 225.4 \\
\hline Agriculture and Rural Development & 3.0 & 4.8 & 10.3 & 29.4 & 26.6 & 44.8 & 85.3 \\
\hline Police, Defence and Ministry of Interieur & 97 & 181 & 216 & 223 & 383 & 488 & 486 \\
\hline \multicolumn{8}{|l|}{ Pro memoire } \\
\hline Total, excluding security spending & 22.4 & 29.4 & 145.1 & 250.5 & 378.9 & 460.7 & 374.0 \\
\hline Total, including security spending & 119.0 & 210.5 & 361.2 & 473.5 & 761.7 & 948.4 & 860.0 \\
\hline Debt relief & 90 & 121 & 225 & 156 & 163 & 178 & 376 \\
\hline \multicolumn{8}{|c|}{ Increase in spending since 2003 as percent of debt relief in current year (2) } \\
\hline Total, excluding security spending & - & 6 & 54 & 146 & 219 & 246 & 94 \\
\hline Total, including security spending & - & 76 & 107 & 227 & 395 & 465 & 197 \\
\hline
\end{tabular}

Note 1: Police, Defence and Ministry of Interieur

Note 2: (Spending in year $x$ - spending in year 2003) as percent of debt relief in year $x$

Sources: Congolese authorities; and IMF and World Bank staff estimates and projections.

\section{Public Expenditure Management}

\section{Implementation of a modernized budget-execution system, providing information from commitment to payment, and allowing for the monitoring of arrears.}

19. Staffs consider this trigger met. The budget-execution system that was set up in 2003 is supported by a new budget nomenclature. The four phases of the expenditure process were restored with specific efforts to streamline the process from commitment to payment, and to guarantee the security of transactions. The modernization of public expenditure management culminated in the development and adoption of a manual of procedures and the automation of the expenditure chain. At any given time, the system can not only provide the 
status of individual expenditure items, but, more importantly, also monitoring reports (ESBs) using different budget classifications which provide up-to-date information covering every stage of the expenditure chain from commitment to payment. The system also allows the monitoring of payment authorizations from the Treasury and actual payments by the BCC, which in turn permits the monitoring of arrears. Based on this information, the stock of arrears is determined and an arrears clearance plan defined.

20. The budget execution system has over the years provided a solid base for the improvement of budget control and expenditure management as the monitoring reports are used by the Ministry of Budget and Treasury to prepare their quarterly commitment and payments plans, respectively. While representing a major improvement over the last few years, expenditure data need to be improved, especially regarding their timeliness and coverage of urgent spending as well as provincial government spending. Under the program supported by the current ECF arrangement, the Treasury and BCC conduct a monthly data reconciliation exercise to further improve the comprehensiveness and reliability of the monitoring reports. Further, the 2003 manual of expenditures was revised in February 2010 to further streamline budget execution and restrict extra-budgetary expenditures. With assistance from the Central AFRITAC and the World Bank, the government is implementing an upgrade plan and a pilot budget management computerization system in three provinces (South Kivu, Bandundu and Katanga), which will prepare the ground for the development and gradual implementation of a fully integrated government financial management information system.

\section{Adoption and implementation of a double-entry government accounting system and a new chart of accounts.}

21. Staffs consider this trigger met. The authorities introduced double-entry accounting in late 2005 starting at the Treasury department with the creation of the Central Accounts Division (CAD) and the development and adoption of a Chart of Accounts, a 12-digit accounting nomenclature for revenues and expenditures, and a procedure manual along with its computerized application. New accounting units and a computer application for accounting were set up within each of the collection department of the three "regies" (Tax, Customs, and Administrative Revenue departments) that transfer the accounting information to the accounting department of the Treasury on a regular basis. A procedure manual was developed to assist with their operations. The production of general ledgers for 2006, 2007 and 2008 was, however, very challenging and experienced much delay. Technical assistance provided by the Central AFRITAC supported this process.

\section{Production of quarterly budget execution reports using economic, administrative, and functional classifications.}

22. The staffs consider this trigger met. The budget nomenclature allows for the presentations of execution reports according to a variety of classifications (i.e., economic, administrative, and functional) consistent with the Fund's 2001 Government Finance Statistics manual. Classification by source of funding (local versus foreign), by geographic location (central versus provincial governments) is also available, in addition to classification 
based on pro-poor spending, including the use of HIPC resources. The system makes it possible to produce reports combining different classifications. Unfortunately, these quarterly reports take time to be updated and reconciled due to the need to include expenditures that do not follow the standard procedures; these are being curtailed with the adoption of a new expenditure management manual. The ESBs are sent on a quarterly basis to the Minister of Finance who oversees budget execution. The improvements under way in expenditure management described in Section D will also improve the reliability and timeliness of the quarterly budget execution reports produced using any of the available classifications.

\section{E. Governance and Service Delivery in Priority Sectors}

\section{Poverty-Related Expenditure Monitoring}

\section{Completion of a budget-tracking exercise on health, education, rural development and infrastructure expenditure, consisting of monitoring the execution of poverty-related} public expenditure. Evaluation by user groups of the quality of related public services, and evaluation by service-providers of constraints to effective provision.

23. Staffs consider this trigger met. The authorities made great efforts to gather information and monitor pro-poor spending. In addition to close monitoring of pro-poor budget expenditures, a multi-topic survey in three provinces (Katanga, Bandundu and Sud-Kivu) was undertaken in late 2009/early 2010 by the National Statistical Institute (INS) and Bureau d'Études, de Recherches et Consulting International (BERCI); a private Congolese consulting firm) with assistance from Agrer Etudes et Conseils (AGRER); a Brussels-based consulting firm) and the World Bank Institute (WBI). The results of these efforts have been summarized in two reports, one on the execution of pro-poor spending and the second on the survey outcomes, both prepared in the context of a collaborative exercise between several Government administrations. Though a full Public Expenditure Tracking Survey (PETS) could not be carried out for technical reasons, ${ }^{10}$ the reports provided a strong platform for assessing the quality of public spending on social services. Likewise, while a full Service Delivery Facility Survey was not conducted, the BERCI/AGRER/INS 2010 survey provided reliable information on the perceived quality of services by users and the bottlenecks identified by providers.

\section{Monitoring the execution of poverty related public expenditures}

\section{The execution of poverty-related public expenditures is monitored through the}

ESB. The ESB allow a comparison of the budget allocation approved by Parliament and the execution as managed by the Sector Ministries and the Ministries of Budget and Finance.

\footnotetext{
${ }^{10}$ A full PETS would have required detailed tracking of expenditures from the central to the lowest administrative level, which was not possible at the time, due to the lack of expertise to implement such a complex exercise, the complexity and evolving nature of the administrative structure toward greater decentralization, the size of the DRC and the costs such survey would entail. In the case of the DRC, a full PETS is expected to take several months and up to one year. The authorities have expressed the intention to conduct such an exercise in the near future.
} 
Budget execution rates in health and education sectors were close to 100 percent by 2009 , compared to less than 60 percent in 2003. The budget allocation for the Ministries of Agriculture and Rural Development was modest, but it was fully executed for the first time in 2008.

\section{The Government also established an inter-ministerial committee to monitor and} prioritize pro-poor public expenditures (Comité Consultatif du Suivi des Dépenses Pro-

Pauvres). This committee was established in the initial stage of PRSP implementation to monitor not just resource allocation between ministries but also pro-poor budget allocations within ministries. It stopped operating in 2006 when the Ministry of Finance (MOF) and the Ministry of Planning started obtaining poverty data directly from the expenditure chain unit and this function was devolved to the line ministries. The execution rate of this pro-poor budget was in the range of 85-95 percent during 2006-08 and over 100 percent during 2009, significantly higher than the average budget execution rate of 66-75 percent.

\section{Service delivery and governance}

\section{Consistent with the HIPC trigger the government conducted a quantitative} assessment of the service delivery realized with the priority spending. With international assistance from AGRER/WBI, the government, through the Ministry of Planning and its INS Department, and local technical assistance of BERCI launched a large survey of user groups (exit poll users and households) of public services in 2010. The survey was stratified at the district level and had nine modules. Four types of users were interviewed: households (3200), individual users of services at the exit of service delivery points (3000), administration agents (800), and providers and managers of firms (290). The survey has been very successful given the logistical difficulties to reach households and services across the country, and the short timeframe to complete the process (about two months). The household component of the survey was linked to a UNICEF-sponsored Multiple Indicator Cluster Survey (MICS) ${ }^{11}$ in three provinces (Katanga, Sud-Kivu, and Bandundu). Infrastructure services were covered from the service providers' perspective while the user/household survey focused on governance and service delivery in social sectors. The survey report prepared by the Ministry of Planning summarized main findings on users' perception of quality of services as well as the perceived bottlenecks by providers. Main findings are reported below and are generally in line with expectations.

\section{Evaluation by user groups of priority public services}

\section{The main findings of the users and households survey can be summarized as}

follows: (a) The DRC is still perceived by its citizens as a fragile state with a high level of corruption. The population has a dim view of the army and police due partly to the low level

\footnotetext{
${ }^{11}$ The MICS is a survey program developed by the United Nations Children's Fund to provide internationally comparable, statistically rigorous data on the socioeconomic situation of children and women (health, education, labor, access to utilities and other social services, etc.). The DRC MICS is unusually comprehensive and is expected to be completed by August 2010. Field data collection is almost complete and data cleaning will begin very shortly.
} 
of interaction between the population and the state (through its administrations and institutions). The DRC's government is perceived as weakly committed to fighting corruption and ill-governance. (b) Despite the increase in pro-poor spending, access to basic services remains inadequate ( 31 percent of households have access to safe water and 15 percent to electricity-poor households do not have access to electricity). In addition, the quality of services remains a major concern for the population, followed by the high cost of these services (which explain the low level of school enrolment in particular). Respondents expressed a willingness to pay more for improved services. (c) Nonetheless, users and households noted a significant improvement in service delivery as compared to 2003.

\section{Evaluation of service providers of constraints to effective provision}

\section{The Bureau d'Études, de Recherches et Consulting International and Agrer} Etudes et Conseils (BERCI/AGRER/INS) survey also gathered information on the constraints faced by public service providers. The sampling methodology was to survey all service infrastructures available in the primary sampling unit (PSU) and ask for available services in a 30-km range if none was available in the PSU. Four enterprises were also covered in each PSU. The key constraints to service delivery were identified as: (a) lack of funding, especially for recurrent expenditures, ${ }^{12}$ (b) lack of investment, (c) low salaries for, and the poor motivation of, staff, (d) shortage of qualified staff, (e) frequency of strikes, and (f) weak institutional structures, including a lack of clear hierarchy within service organizations.

29. Main recommendations of the report are to: (a) increase resources available to ministries, sectors and services, by direct transfers, and raise institutional effectiveness through the decentralization, (b) improve salaries, (c) clarify roles and responsibilities, (d) combat corruption and fraud by reinforcing controls, (e) increase the number of staff and strengthen training and performance, (f) improve administrations' capacity, and

(g) regularize "unofficial" staff. The Ministry of Planning fully endorsed the recommendations and is preparing an action plan to address the most egregious failures described above.

\section{The IMF and World Bank staffs note that the reports are good platforms to} inform government future action. There is scope for exploiting the available data further, a step that the authorities have promised to take in the near future. Similarly, analysis of service delivery in infrastructure (especially roads and energy) should be given greater attention and resources as they are major contributors to poverty alleviation. Lastly, there is scope for additional analytical work on public enterprises and understanding more deeply the reasons behind the slow disbursement rate of projects. The authorities' recent efforts under the Projet de Renforcement de Capacite et de Gouvernance (PRCG) to prepare the analytical foundations for public sector restructuring, including in particular effective separation of retirees in selected ministries, are steps in the right direction.

\footnotetext{
${ }^{12}$ This impacted more directly logistics support (buildings, cars, furnished materials) and maintenance of infrastructures.
} 
Adoption and implementation of a new procurement code and key implementing decrees

31. The staffs consider this trigger as met since a new public procurement law was adopted and its implementation process has been found satisfactory. The new Procurement Law prepared with assistance from the World Bank and the Canadian Cooperation was adopted by Parliament and signed by the President on April 27, 2010 with an improved legal and regulatory framework. Transparency is most evident in the sense that (i) all contract opportunities are largely publicly advertised; (ii) contract award decisions are to be published in addition to formal notification to bidders; (iii) there will be a free and independent complaints review mechanism through the Agence de Regulation de Marches Publics (ARMP); and (iv) ARMP will be involved in all aspects related to the regulation of the new system and is expected to play a major role in limiting political interference. The administrative and institutional elements to support the new code have been put in place including the relevant secondary legal acts; the creation and staffing of a Public Procurement Directorate (DGCMP) which is tasked with overall responsibility to review and give no objection on procurement decisions, including bid documents for large contracts; the nomination and installation of the board of the ARMP.

\section{The authorities completed all of the administrative steps to support the} satisfactory application of the new code. The recruitment process of the staffs of the operational unit of the regulatory body that includes the General Directorate and the Bidders' Complaint Unit is ongoing. The main responsibility of the Bidder's Complaint Unit that reports to the board of the ARMP is to ensure that effective procedures are implemented for resolving disputes and that all complaints that may arise during the procurement process are properly addressed. By end of July 2010, procurement units (CGMPs) will be set up in seven line ministries that include Education, Health, Infrastructure, Budget, Energy, Environment and Agriculture and three pilot provinces that include Bas Congo, Kinshasa, Province Orientale.

33. To facilitate implementation of the Code, a manual of procedures for executing agencies, standard bidding documents, and a description of the general conditions of contracts have been prepared, and the training program on these tools is scheduled to start by end-September 2010, soon after the firm assigned to provide the needed technical assistance is selected.

34. According to Clause 83 of the Procurement Law, the new procurement system will be enforced six months after its approval and promulgation-i.e., no later than October 2010. In addition, the government has committed to conduct after one year of implementation of the new procurement law, an audit under the control and supervision of the board of the ARMP. Further, the ARMP will assess the implementation of the whole procurement system by end-April 2011.

35. The Minister of Budget has communicated to the IMF and the World Bank staffs a detailed implementation report based on inputs received from ARMP, COREF (Comité d'Orientation des Réformes des Finances Publiques) and COREMAP (Comité de Réforme des Marchés Publics). The report is accompanied with supportive documents related to (i) the installation of the board of ARMP, (ii) the final approval of the application 
texts that include mainly a procedure manual and the text regulating the organization and the functioning of the ARMP; (iii) the progress in the recruitment process of the key personnel of the ARMP operational unit; and (iv) the progress in the selection process of the firm that will provide technical assistance to the new institution including the training of all actors on procurement matters in the PFM system that includes procurement.

\section{F. Social and Rural Sector Strategies}

\section{Adoption of satisfactory sectoral development strategies and related implementation plans for health, education and rural development.}

\section{Health}

36. The staffs consider the trigger met since a National Health Sector Strategy (NHSS) and a National Health Development Plan (NHDP) 2011-15 were validated by the Ministry of Health and development partners on March 31, 2010. The NHDP is the first multiyear implementation plan for NHSS adopted in 2006 and revised in 2010. To reduce fragmentation of services in health zones and vertical interventions of partners, the 2006 NHSS had emphasized the importance of an integrated approach to basic health service provision through revitalization of health zones and alignment of donor interventions. The revised strategy aims to further strengthen these aspects both operationally and institutionally, while strengthening government ownership in managing health development programs. The revised strategy includes six strategic axes of intervention and focuses on lead areas where progress will determine success of the overall health of the population:

(i) revitalization of health zones; (ii) strengthening government ownership and leadership; (iii) development of health human resources; (iv) pharmaceutical sector reform; (v) health financing reform; (vi) inter- and intra sector partnerships; and (vii) strengthening health system-related research. The Declaration made by the health sector Donor Coordination Group (Groupe inter-bailleurs de santé-GIBS) in Kinshasa on the day of the adoption of the strategy demonstrates a political commitment by the donors to align their interventions to the government's strategy. Revision of the NHSS took a participatory approach involving delegates from Provincial levels (Provincial Health Ministers and Provincial Medical Inspectors). It also took into account the analyses and diagnoses carried out for each province in the process of NHDP elaboration.

37. The NHDP, whose five year planning cycle is aimed at coinciding with the second generation PRSP under preparation, was finalized under the leadership of the Prime Minister. It outlines four major implementing goals: (i) providing the basis for implementing the "Health Chantier" of the DRC and serving as the common framework for the Government and its partners in pursuit of the Millennium Development Goals (MDGs); (ii) making the NHSS operational with a main focus on primary health care responding to the needs of the Congolese population; (iii) developing a strategic tool to guide the implementation of decentralization in the health sector through the establishment of new provincial directorates that have greater autonomy to organize health services and to manage resources; and (iv) providing the basis to reconcile provincial plans and the national planning cycle that will serve as the reference for preparation of the annual budget allocated to health. 
38. The overarching objective of the NHDP is to contribute to the improvement of the general health status of the population and containment of endemics and transmittal diseases, while the sector objective is to ensure access of the entire population to primary health care, with special focus on vulnerable groups. The Plan analyzes in detail the key health challenges in the DRC and identifies concrete actions to be taken in the next five years. The NHDP was developed through a participatory approach involving all levels of the health system - central, intermediate and peripheral - and was elaborated based on Provincial Health Development Plans that were based on the Health Zone Development Plans in their respective provinces. Implementation of the NHDP will build on this approach, thus allowing the health zone levels to benefit from experiences of other levels of the health system pyramid. The Plan will also help partners align their future interventions on the sector priorities. This strategy is expected to yield much greater results in addressing the key health challenges of the country such as infant mortality, maternal health, malaria incidence, respiratory diseases, and HIV/AIDS in addition to strengthening the statistical base for closer monitoring of trends in the sector.

\section{Education sector}

39. The staffs consider the trigger met. The Council of Ministers adopted on March 18, 2010, the basic Education Strategy ${ }^{13}$ along with a priority action plan. The strategy, which has also been intensively reviewed by the donor community and validated in a national workshop, built on a series of thematic analytical pieces and benefitted from recommendations from an independent committee of specialists and local leaders. It is accompanied by a medium term expenditure framework that will help assure sustained implementation of priority policies as well as associated budgetary expenditures. Preparation of the strategy involved organization of consultations and workshops with the participation of a wide range of stakeholders-parent associations, teacher associations, NGOs, local administration, etc.

\section{The strategy document has put forward strategic framework to ensure a more} equitable and sustainable access to basic education of acceptable quality. To this end, it has set three strategic objectives; (i) improving access and retention in basic education; (ii) improving the quality and pertinence of basic education where the government intends to strengthen its role as a regulator and quality controller over the numerous non-public education providers; and (iii) strengthening the management and governance of the systemthis also aims at deepening provincial authorities' responsibilities in education management. Guided by results of simulation work, it also articulated a set of specific policy measures to address the main factors that in the past have constrained education sector efficiency and outcomes. These include (i) concrete measures to reduce direct costs of education to households, especially those in rural areas; (ii) empowering community involvement in school management and increasing accountability of all actors for educational outcomes; (iii) over-hauling teacher in-service training with the view to improving teacher productivity

\footnotetext{
${ }^{13}$ Basic education is defined as primary and secondary education.
} 
and professional development; and (iv) emphasizing student learning assessment. A key short term objective for the government is to raise the currently low retention rate of about 50 percent significantly over the next five years.

\section{The priority action plan focuses on the planned fee-free policy and other critical actions and/or studies required to further operationalize policy options laid out in the} strategy document. In particular, it has already identified steps, actions, monitoring framework, and resources needed for launching a gradual implementation of the fee-free policy at the primary school level starting with the next school year (September 2010).

\section{Agriculture and Rural Development sector}

\section{Staffs consider the trigger in this area to have been met. In the context of the} restructuring of the Ministry of Agriculture and the creation of the Ministry of Rural Development launched in 2008, a collaboration mechanism was put in place so as to coordinate efforts at the level of the public administration in the elaboration of a new sector strategy. The establishment of Agriculture and Rural Management Councils at district level was the main platform for a participatory process at the provincial level. The Belgian Cooperation, FAO, AfDB and the World Bank contributed significantly during the past year to these developments. The two ministries of Agriculture and Rural Development have finalized an agriculture and rural development sector strategy based on the findings of the 2006 analytical rural sector review and the agriculture policy note of May 2009. The strategy represents the first robust attempt at harmonizing the agriculture and rural development strategies and defining an implementation plan at all levels. A validation workshop of the strategy was held on March 25, 2010, with extensive attendance from numerous stakeholders, including all donors involved in this sector. The strategy and action plan were jointly approved by the two Ministers, and adopted by the Council of Ministers on April 30, 2010. The strategy is consistent with the country's PRSP pillars and its overarching objective is to reduce poverty and improve food security by re-launching agricultural production and enabling better access to basic social services by the rural poor. It has five strategic axes: (i) improving access to markets by enhancing rural infrastructure;

(ii) increasing crop, animal, fishery and artisanal production; (iii) improving access to financing (with specific focus on microfinance); (iv) strengthening governance and institutional capacity; and (v) supporting the development of rural institutions especially public, private, research, extension, and village cooperatives. In terms of management of natural resources, the strategy aims at accelerating the adoption of laws related to natural resources management and protection of vegetal and animal products, an on-going work under the responsibility of the central government.

\section{The agriculture and rural development strategy represents a common vision for} the two ministries given the complementary nature of their activities. Its implementation will ensure donor alignment around the five agreed axes. This strategy is also being complemented by a set of provincial, agricultural and rural development strategies and action plans that will facilitate geographic and sector linkages. These provincial plans are currently being completed with the support of different donors, including the World Bank. In addition, the overall sector strategy will be supplemented by the Agricultural Code recently adopted by the Senate and is expected to be promulgated soon as a law. The Agricultural Code defines 
more precisely the strategy to boost agricultural production at the local level, but also on a larger scale, including private agribusiness. It is built around five strategic chapters: (i) land tenure security; (ii) access to renewable sources of energy; (iii) research, information, and training and technology access; (iv) infrastructure; and (v) fiscal regime. Implementation of this strategy will be carried out through a combination of public-private initiatives, including an explicit role devoted to local communities organized at district level within the Agriculture and Rural Management Counsels (CARG-Conseils Agricoles and Bureau de Gestion) now in place in most of the territories. A monitoring and evaluation mechanism has also been defined in the strategy that will be put in place to oversee implementation.

\section{G. Debt Management}

Installation and full activation of a computerized debt-recording system, covering all public and publicly guaranteed debt, as well as public enterprise debt not carrying the guarantee of the state that can (a) produce monthly debt-service projections, and incorporate actual disbursement and debt-service payment execution data; and (b) support the centralization of debt information in a single center. In addition, monthly debt-service projections that will be published in advance on a quarterly basis.

44. Staffs consider the trigger met. The Direction Generale de la Dette Publique (DGDP) is the agency within the Ministry of Finance responsible for the analysis and management of the public debt portfolio. A computerized Debt Management and Financial Analysis System (DMFAS) capable of producing external debt reports is operating at the DGDP. The system, as well as DSM+ software for debt management and analysis, was installed in 2005 with joint financing from the IDA and the AfDB and with technical assistance from the United Nations Conference on Trade and Development (UNCTAD). Capacity in using the system has been reinforced through training by UNCTAD; but more training is needed to fully familiarize local staff with the system's more advanced functions. A more long-standing problem has been lack of coordination and monitoring of the government's debt policy. As a first step toward addressing this problem, a Prime Ministerial Decree (No. 08/04 dated February 26, 2008) assigned DGDP the sole responsibility for centralizing and managing public debt; this was followed by the development of an Implementation Action Plan, which was endorsed by the Ministry of Finance. The legal mandate assigned to DGDP as well as the Action Plan have been regularly publicized since November 2009, with assistance from AfDB under the Projet dÚrgence dÁttenuation des Impacts de la Crise Financiere (PUAICF). The government is currently preparing a progress report on these activities. While awaiting approval of the official debt management strategy, the government, under its program supported by the ECF arrangement, reaffirmed its commitment to refrain from contracting nonconcessional debt.

45. A well documented debt database, covering domestic and external debt data, has been established and is being maintained. The debt records in the database contain data on external public and publicly guaranteed debt, as well as preliminary data for enterprises with more than 50 percent government ownership, all in a format that follows international standards. State enterprise debt data was collected through surveys in March 2010. The 
database also contains a sizeable amount of data on domestic debt ${ }^{14}$, which is largely in the form of government arrears that date back to the conflict period in the 1990s. The debt records contain both aggregated and disaggregated data on all debt outstanding and disbursed for public and publicly guaranteed domestic and external debt as of December 31, 2009. On the basis of the database, DGDP produces periodic debt reports with relatively short lags. Recording of loan disbursements into DMFAS has improved but remains a challenge. Recording of data on debt service payments are done on a monthly basis after full reconciliation of the external debt accounts with the Central Bank and the ministries in charge of budget and finance. In every quarter, DGDP prepares monthly debt service due and provides it to the Ministry of Finance for payments.

\section{Institutional capacity for an annual publication of public debt data is being} developed. Three annual debt statistical bulletins were published at end 2008, 2009 and March 2010. The last, which includes debt data assessed at December 31, 2009, is consistent with international standards, in terms of scope and information content. They are available on the government's website. The plan is to have these data produced on a half-yearly basis in 2010 and on a quarterly basis thereafter. The functionality of DMFAS, the training and experience gained by DGDP over the years, as well as the clear mandate that has been given to the agency through a Prime Ministerial Decree to produce statistical debt bulletins, provide solid assurance that public debt data management has taken hold in the DRC.

\section{The authorities need to consolidate the gains achieved so far in improving public} debt management. The authorities are aware of the need to give more functionality to the DMFAS system by integrating it electronically with the expenditure chain. For this purpose DGDP has already prepared a project for the acquisition of DMFAS VI which allows this integration through Web-based technology. This will greatly reduce the time necessary to effect debt service payments and record transactions, and thus will minimize the possibility of inadvertent late payments. The project has been prepared in collaboration with UNCTAD and is now awaiting donor financing of approximately US\$550,000. DGDP has also prepared a matrix of immediate actions that will help address other problems in this area consistent with the DeMPA, such as greater involvement of DGDP in external resource negotiations, digitizing documentation, capacity building in the use of information technology, strengthened data management processes, and quality control. In collaboration with the ministries of Budget and Treasury, DGDP is also preparing an action plan to strengthen capacity in the collection of domestic debt data including arrears for non central government institutions and agencies.

\section{UPDATED DEBT RELIEF AND DEBT SUSTAINABILITY ANALYSIS}

48. The stock of HIPC-eligible external debt in PV terms at end-December 2002, was revised upward following the debt reconciliation exercise. The staffs of the IMF and the IDA, together with the Congolese authorities, reviewed the end-December 2002, stock of debt data that was presented in the decision point document against recent creditor

\footnotetext{
${ }^{14}$ Estimated at US\$1.3 billion most of which are being negotiated.
} 
information. As a result, the nominal stock of debt has increased by US\$113 million to US\$10,772 million, and the PV of debt after traditional debt relief has been revised upward by US $\$ 933$ million to US $\$ 8,801$ million (see Table 4). The revision is attributable to the following changes in the external debt.

- Multilateral creditors. The total multilateral debt stock as of end-December 2002, has increased by US $\$ 46$ million in nominal terms. This change was primarily due to the addition of debt involving BDEGL, with whom the government had suspended relations at the time of the decision point. These included direct outstanding loans from BDEGL to the government, guarantees by the government on loans made to BDEGL by the AfDB Group, and a direct non-guaranteed loan to a public enterprise from BDEGL. ${ }^{15}$ The corresponding PV in end-2002 terms was revised upward from US $\$ 3,077$ million to US\$3,196 million due to new information available at the time of the completion point reconciliation mission, which led to revisions in the PV of debt outstanding at end-2002 to a number of creditors, including the IMF and the AfDB group. ${ }^{16}$

- $\quad$ Paris Club creditors. Most of the upward revision to the PV of outstanding debt at decision point after traditional debt relief mechanisms is attributable to revisions in Paris Club claims. The PV of debt to Paris Club creditors at end-December 2002, after traditional debt relief has been revised from US $\$ 4,318$ million to US $\$ 4,944$ million. This increase by US $\$ 626$ million is attributable to more recent data available as a result of the reconciliation mission at Completion Point. ${ }^{17}$

- Other official bilateral creditors. The nominal value of the stock of debt owed to other official bilateral creditors has increased by US $\$ 11$ million to US $\$ 448$ million

\footnotetext{
${ }^{15}$ Other minor changes in nominal terms included revisions to the debt outstanding to IFAD and AfDF due to revisions in the database used at decision point discovered during the debt reconciliation mission.
}

\footnotetext{
${ }^{16}$ Smaller changes were made to the PV as of end-2002 of IDA, IFAD and BEAC. In addition, revisions were made to debt outstanding to BDEGL, the IMF and the AfDB group. The PV of debt to the AfDB was revised upward compared to the decision point estimates based on (i) changes in the PV of debt of the AfDB due to revised estimates of the amount of arrears and current maturities at end-2002; and (ii) revisions to the estimate of HIPC relief delivered by the AfDB group on the loan approved by the AfDB to clear the arrears of the DRC at the time of the decision point. These revisions were agreed to between the World Bank and the AfDB in January 2004. Finally, the PV of debt outstanding to the IMF was revised downward as compared to the decision point due to revisions in projected interest payments.
}

${ }^{17}$ Missing claims held by the Paris Club creditors are now included in the debt stock. The large difference in the claims for Belgium is due to the change in methodology from Debt Service Reduction to Debt Reduction for providing relief based on the September 2002 Paris Club minutes along with including missing claims as of the decision point. 
and the corresponding PV of debt after traditional relief has increased to US\$278 million in December 2002 terms. ${ }^{18}$

- Commercial creditors. The increase in the stock of outstanding commercial debt at end-December 2002, by US\$337 million reflects the inclusion of claims previously not included in the decision point database.

49. Exports of goods and services have changed slightly. The estimate of the 2000-02 average of exports of goods and services used to evaluate HIPC assistance at the decision point declined from US $\$ 1,038$ million to US $\$ 1,033$ million due to data revisions.

\section{A. Revision of HIPC Assistance and Status of Creditor Participation}

50. The required HIPC assistance at end-December 2002, PV terms has been revised upward from US\$6,311 million estimated at the decision point to US\$7,252 million. As a result, the common reduction factor (CRF) has marginally increased from 80.2 percent to 82.4 percent (Table 5). ${ }^{19}$

51. At the completion point, the DRC has received financing assurances by creditors accounting for about 96 percent of the revised PV of HIPC assistance estimated at the decision point (Table 7). All multilateral creditors (of which IDA, the IMF, and the AfDB Group comprise 32.2 percent of total HIPC assistance) with two exceptions ${ }^{20}$ and all Paris Club creditors ( 56 percent of total HIPC assistance) have confirmed their participation. China provided outright cancellation of some of its claims in 2007.

\section{Multilateral Creditors}

52. The revised amount of enhanced HIPC assistance from multilateral creditors is US\$2,633 million at end-December 2002, PV terms. The IMF, the IDA, the AfDB Group, and the EU have provided HIPC debt relief through both arrears clearance operations and interim relief. IFAD, BADEA, BEAC and EIB have delivered a portion of their HIPC assistance through arrears restructurings.

\footnotetext{
${ }^{18}$ Claims now include revisions based on more updated information including claims held by Romania that are now included in the debt stock.

${ }^{19}$ In accordance with the "Information Reporting in the Context of HIPC Initiative Assistance", the assistance for the DRC will be revised upward based on the new common reduction factor of 82.4 percent.

${ }^{20}$ At end-December 2002, the authorities had US\$52.3 million in arrears to BDEGL and are negotiating with the bank regarding debt relief. DRC's debt to BEAC results from unpaid amounts due as a result of clearinghouse operations undertaken by BEAC on behalf of the Communauté des Etats de l'Afrique Centrale (CEAC), amounting to $\$ 30$ million SDRs in 1993, when the first of several reschedulings took place. BEAC has subsequently rescheduled its DRC debt on multiple occasions: in 1995, 2001, 2004, and 2008. Authorities are currently on track with the most recent BEAC rescheduling and are scheduled to pay off the debt in December 2011.
} 
- The IMF. As a result of the revisions of the PV of debt as of the decision point and the changes in the common reduction factor discussed above, the IMF's share in debt relief for the DRC under the HIPC Initiative amounts to SDR 337.5 million (US\$471.5 million) in PV terms, slightly lower than the amount calculated at the decision point (SDR 337.8 million or US $\$ 472.0$ million). Of this amount, SDR 57.2 million (equivalent to about US\$79.9 million) has been delivered through the concessional element associated with the disbursement of an ECF (formerly PRGF) loan following the DRC's arrears clearance to the IMF in June 2002, which is counted toward the IMF's contribution to HIPC assistance. The amount, however, is significantly lower than the SDR 109.6 million (US\$153.1 million) assumed at the time of the decision point. ${ }^{21}$ To ensure that the DRC receives the full share of assistance from the IMF under the HIPC Initiative, IMF staff proposes that the amount of the grant assistance approved at the decision point (SDR 228.3 million) be increased by SDR 52 million to SDR 280.3 million in view of the lower-thanassumed concessional element associated with the ECF loan and taking into account the revised DSA. The IMF has already approved SDR 49.1 million in the form of interim HIPC assistance to meet the DRC's debt service payments to the Fund. The remaining SDR 231.2 million (in PV terms) would be delivered at the completion point through a stock-of-debt operation (see Table 13).

The IDA. Debt relief has been delivered through the clearance of arrears and debt service reduction during the interim period amounting to US $\$ 442.7$ million in decision point PV terms or 52 percent of total HIPC relief estimated at the decision point. ${ }^{22}$ The IDA is assumed to provide the remaining amount of relief through a 90 percent reduction of the DRC's debt service through November 2027.

The AfDB Group. Debt relief amounting to US\$571.6 million or 57 percent of the AfDB Group's total debt relief has been delivered through the restructuring of arrears at decision point and debt service reduction during the interim period. The remainder

\footnotetext{
${ }^{21}$ This reflects lower than projected interest rates and shortening of the repayment period due to the MDRI stock delivery of debt relief at completion point.
}

\footnotetext{
${ }^{22}$ IDA arrears clearance amounted to $\$ 222.7$ million in PV terms at decision point. Three modalities were used to deliver the IDA's Enhanced HIPC debt relief. First, on July 3, 2002, arrears owed to IBRD and to IDA by the DRC were cleared through a bridge loan which was repaid through the first tranche of the Emergency Recovery Credit, resulting in an PV reduction of US\$199.2 million in end-2002 terms - of which US\$78.2 million resulted from the treatment of arrears owed to IBRD, and US\$121.0 million from the treatment of arrears owed to IDA - which was applied to Enhanced HIPC debt relief on debts owed to IDA. Second, on July 31, 2001, the Executive Directors approved the post-conflict Emergency Early Recovery Grant in the amount of SDR 40 million, equivalent to a PV reduction of US\$23.5 million in end-2002 terms, to be applied to Enhanced HIPC debt relief on debts owed to IDA. Third, the Executive Directors approved the provision of interim debt relief beginning in August 2003, through a reduction of 90.0 percent of the debt service falling due on disbursed and outstanding IDA debt as of December 31, 2002.
} 
of the AfDB Group's HIPC relief is assumed to be delivered through an 80 percent reduction of the DRC's debt service from the completion point until July 2022.

- Other multilateral creditors. The modalities of assistance by all other multilateral creditors: BADEA, EU, EIB, IFAD, BEAC, BDEGL, IFC, and OFID are summarized in Table 7.

\section{Bilateral and commercial creditors}

53. Paris Club creditors have agreed in principle to provide their share of enhanced HIPC assistance (estimated at US\$4074 million in end-December 2002 PV terms, in accordance with the revised assistance, see Table 5). The major Paris Club creditors are the United States and France with 15.5 percent and 10.8 percent, respectively, of the HIPC eligible debt stock at end-December 2002, followed by Belgium and Japan with approximately 7 percent of the debt stock. Interim assistance has been delivered through a flow rescheduling on Cologne terms during the interim period, agreed in November 2003. Switzerland has already delivered its share of debt relief by cancelling 100 percent of its claims in 2003. Several Paris Club creditors will also provide additional debt relief beyond obligations under the HIPC Initiative, including 100 percent stock-of-debt cancellation (see Table 15). This additional relief is estimated at about US\$47 million at end-December 2009, PV terms.

\section{Non-Paris Club bilateral creditors are assumed to provide relief on HIPC-} eligible debt on terms comparable to those of the Paris Club. The PV of HIPC relief expected from non-Paris Club creditors at end-December 2002, is estimated at US\$229 million. The major non-Paris Club creditor is the United Arab Emirates comprising 1.6 percent of HIPC-eligible debt, followed by Kuwait ( 0.9 percent), China, Serbia and Montenegro (former Yugoslavia) and Taiwan, Province of China ( 0.4 percent each). The authorities have negotiated relief efforts in the interim period with some of Non-Paris Club bilateral creditors ${ }^{23}$ and are working toward reaching agreements on provision of the remaining debt relief at completion point with all non-Paris Club creditors.

\section{Several commercial creditors have provided HIPC comparable relief in the interim}

period. The commercial debt has been divided into claims held by the London $\mathrm{Club}^{24}$ and nonLondon club creditors. Several missing claims have now been included in the debt stock as of endDecember 2002, which has almost doubled from the figure that was used at Decision Point. For most of these claims the authorities have managed to obtain rescheduling on HIPC comparable terms. As of end-December 2009, the claims held by commercial creditors fell by about US $\$ 400$ million to US\$214 million in nominal terms. Currently the DRC is in the process of negotiating a buy-back operation supported by the IDA's Debt Reduction Facility (DRF) to extinguish the remaining HIPC eligible commercial claims as of end-December 2009.

\footnotetext{
${ }^{23}$ In 2007, China cancelled outstanding claims, amounting to US\$29 million in nominal amounts as of end-December 2002, and Egypt cancelled 100 percent of its claims in 2008. Israel cancelled approximately US\$28 million in 2007 and rescheduled US\$6 million while Kuwait Fund cancelled 100 percent of the interest held in arrears as of 2004.

${ }^{24}$ Claims of the London Club creditors shown in Table 4 do not include claims held by the Belgolaise Bank for reasons described in Box 2.
} 


\section{Box 2. The Democratic Republic of the Congo: The Treatment of Claims held by Belgolaise Bank}

Belgolaise Bank (la Banque Belgolaise) ${ }^{1}$ holds the largest share of commercial external debt claims of the DRC owed to the London Club, of which Belgolaise Bank is a member. Calculations by the IMF staff based on records provided by the Union Bank of California (the Servicing Bank for London Club creditors with claims on the DRC) indicate that at end-2009 interest in arrears to London Club creditors totaled \$546.3 million, implying total claims of US\$897.3 million, 91 percent of which (US\$816.5 million) is held by Belgolaise.

From the HIPC Completion Point perspective, the Belgolaise debt is currently being identified as "passive debt". ${ }^{2}$ In April 2008, senior officials of Belgolaise stated in a letter to the DRC authorities that Belgolaise Bank irrevocably renounced then and in the future to pursue the recovery of their claims. ${ }^{3}$ Since then, Belgolaise has continued not to bill the DRC. Thus the Belgolaise debt is being identified as 'passive'. Such issues have arisen in the past under the HIPC Initiative, although this is the first time that it involves a private creditor. ${ }^{4}$

Passive debt is excluded from the HIPC-eligible debt stock. The rationale for this treatment is to avoid unduly inflating the common reduction factor, which would require all creditors to provide higher debt relief on account of a debt that is not expected to be collected. The downside of such a treatment is that a passive debt can, in principle, become active again after the HIPC completion point. In such a case, the holder of the formerly passive claim would still be expected to provide HIPC debt relief. However, the debtor would not be able to get the additional relief it would have received from the other creditors had the CRF been higher in the first place. ${ }^{5}$

At the HIPC decision point, Belgolaise debt was not included in HIPC-eligible debt stock because no information was available on this claim at the time. Including the Belgolaise claim in the calculations would increase the PV of debt after traditional debt relief at end-2002 from US $\$ 8,801$ million to US $\$ 9,019$ million, which would imply a higher common reduction factor (82.8 percent instead of 82.4 percent) in order to reduce the external debt-to-export ratio to 150 percent. The higher common reduction factor implies that the amount of assistance provided by creditors other than Belgolaise would increase from US\$7,252 million to US\$7,470 million (in PV terms). For the IMF and the IDA, the additional effort would increase from US\$2.4 million to US\$4.4 million (in PV terms).

The Belgolaise claim is currently being considered in the context of on-going negotiations between the DRC authorities and Belgolaise. In September 2005, the DRC benefited from an IDA Debt Reduction Facility (DRF) Preparation Grant to finance legal and financial advisory services to assist the DRC in the preparation of an external commercial debt buyback operation. The DRF Preparation Grant reached its closing date on June 30, 2010.

${ }^{1}$ In 1989 Generale Bank (Générale de Banque) had a controlling share (55 percent equity ownership) of Belgolaise. In 1999 Generale Bank was acquired by Fortis, which operated Belgolaise as subsidiary in sub-Saharan African. In early 2005, Fortis put Belgolaise up for sale but was unable to find a suitable buyer. Belgolaise ceased all operations after October 2006. Belgolaise no longer carries out banking activities and is no longer a credit institution but does still exist as a corporate entity in the form of a Belgian law limited company, and is now part of the BNP Paribas Fortis group.

${ }^{2}$ HIPC Initiative guidelines identify passive debt as follows: "The debtor country authorities may classify some external obligations kept on their books as passive debt on the basis of the following presumptions: (i) formal requests to resume debt service payments or to regularize arrears have not been received from the creditor concerned for a long time; and/or (ii) there has been an informal understanding between the debtor country authorities and the creditor concerned on a temporary or indefinite (without termination clause) waiver of debt service payments on the basis of the initial payments schedules."

${ }^{3}$ The letter was signed by the Managing Director and Chairman of Board of Belgolaise.

${ }^{4}$ The treatment of a debt as passive was originally conceived for a sovereign creditor, whose views about the treatment of the claim could have been sought during the IMF and the IDA Board discussions.

${ }^{5}$ For example, when Mauritania reached its Completion Point in 2002, claims held by Arab governments and state-owned development agencies were identified as passive and therefore excluded from the calculation of the common reduction factor. The creditors subsequently requested payment on such claims. These claims are currently being negotiated for the provision of debt relief consistent with the common reduction factor estimated at the completion point for Mauritania in the enhanced HIPC Initiative. 


\section{B. Considerations for Exceptional Topping-Up Assistance}

\section{The Debt Relief Analysis (DRA) has been updated jointly by the authorities and} the IMF and IDA staffs on the basis of loan-by-loan debt data, exchange rates and interest rates as of end-December 2009 (Table 6). ${ }^{25}$ At end-December 2009, the nominal stock of the DRC's external debt amounted to US\$13,704 million (see Table 8). Multilateral creditors accounted for US $\$ 4,986$ million or 36.4 percent of total nominal debt, of which the IMF, the IDA, and the AfDB Group accounted for 5.8, 18.2 and 10.3 percent, respectively. Paris Club creditors accounted for 54.5 percent of total outstanding nominal debt at end-December 2009, while non-Paris Club creditors accounted for 7.5 percent of total debt, of which the large creditors are China, Kuwait and the UAE.

\section{The DRC does not qualify for topping-up. The ratio of PV of debt-to-exports at} end-December 2009 - after full delivery of the HIPC assistance committed at the decision point - is now estimated at 44.2 percent, which is 53 percentage points below the projection at time of the decision point. The ratio of PV of debt-to-exports - after the full delivery of additional voluntary bilateral debt relief beyond the HIPC Initiative at end-December 2009would further decline to 43.3 percent, which is below the 150 percent threshold for consideration of topping-up assistance defined under the enhanced HIPC Initiative (see Table 3). ${ }^{26}$ Higher-than-expected exports and lower-than-expected new borrowing mainly explain why the PV of the debt-to-exports ratio at end-2009 is 53 percentage point lower than anticipated at the time of the decision point. ${ }^{27}$

\footnotetext{
${ }^{25}$ This section updates the debt sustainability analysis using the HIPC DRA methodology, while Appendix II provides a forward-looking update using the Low-Income Countries Debt Sustainability Framework (LIC DSA) methodology.

${ }^{26}$ The debt stock after delivery beyond the HIPC relief is used as a base for topping up consideration. See "The Enhanced HIPC Initiative - Completion Point Considerations," www.imf.org and IDA/SecM2001-0539/1 $(8 / 21 / 2001)$.

${ }^{27}$ The actual figure for the three year average of exports of services at end-2009 are higher than what was assumed at the decision point, which was estimated by using comparator country data.
} 
Table 3. Democratic Republic of the Congo: Breakdown of the increase of PV of Debt-to-Exports Ratio, end-December $2009^{1}$

\begin{tabular}{|c|c|c|}
\hline & $\begin{array}{r}\text { Percentage } \\
\text { Points } \\
\end{array}$ & Percent of Total Change \\
\hline PV of debt-to-exports ratio (as projected at the Decision Point) & 97.2 & \\
\hline PV of debt-to-exports ratio (actual) & 44.2 & \\
\hline Unanticipated change in the ratio & -53.0 & 100.0 \\
\hline 1. Due to changes in the parameters & 8.5 & -16.1 \\
\hline Of which: due to changes in the discount rates & 3.2 & -6.0 \\
\hline Of which: due to changes in the exchange rates & 5.4 & -10.2 \\
\hline 2. Due to unanticipated new borrowing & -4.3 & 8.1 \\
\hline Of which: due to lower than expected disbursements & -11.4 & 21.4 \\
\hline Of which: due to lower concessionality of the loans & 7.0 & -13.3 \\
\hline 3. Due to unanticipated changes in exports & -68.6 & 129.5 \\
\hline 4. Due to changes in HIPC relief and other factors ${ }^{2}$ & 11.4 & -21.5 \\
\hline PV of debt-to-revenue ratio (actual) & 44.2 & \\
\hline Bilateral debt relief beyond HIPC & -0.9 & \\
\hline $\begin{array}{l}\text { PV of debt-to-exports ratio after full delivery of HIPC assistance } \\
\text { and bilateral debt relief beyond HIPC (actual) }\end{array}$ & 43.3 & \\
\hline
\end{tabular}

Sources: IMF and World Bank staff estimates.

${ }^{1} \mathrm{PV}$ of debt-to-exports ratio after full delivery of enhanced HIPC assistance.

${ }^{2}$ DRC's program w ent off track in the latter half of 2006. This affected the initial assumption of the timing of the completion point, and the expected interim relief. The revisions to the decision point debt database at completion point and the changes in the timing of interim assistance delivery pushed this ratio up by 21.4 percentage points.

\section{Creditor Participation in the MDRI}

58. Conditional on reaching the completion point under the enhanced HIPC Initiative, the DRC would qualify for additional debt relief under the MDRI from the IDA and the AfDB Group. While the IMF also provides MDRI assistance, because of an extended interim period and revision of the HIPC assistance, the estimated balance in the DRC's HIPC Initiative Umbrella Account is sufficient to cover the remaining MDRI-eligible debt. As a result, even though all debt disbursed before end-2004 and still outstanding will be cancelled, there will be no resources needed from the MDRI-I Trust. In addition, the EU LDC Initiative will provide a full debt relief on selected EU loans that are still outstanding after HIPC assistance.

- MDRI from the IDA. The IDA would provide debt relief under the MDRI amounting to US\$887.0 million in nominal terms (see Table 14). The IDA would provide MDRI debt forgiveness by irrevocably canceling the DRC's debt service obligations for credits disbursed before end-2003 and still outstanding at 
end-September 2010, after the application of HIPC assistance. MDRI debt relief from the IDA would imply average debt service savings (net of HIPC assistance) of US\$28.4 million per year until 2043.

- MDRI from the African Development Fund (AfDF). The AfDF would provide debt relief to the DRC under the MDRI amounting to US\$162.8 million in nominal terms starting from the completion point. This amount is calculated based on debt disbursed as of December 31, 2004, and still outstanding on July 1, 2010. This implies an average debt service savings (net of HIPC assistance) of US\$3.9 million per year until 2053.

- The EU LDC Initiative ${ }^{28}$ Through the LDC Initiative, the EU will provide additional resources in the form of 100 percent cancellation of future debt service of US \$75.3 million on selected loans over-and-above relief provided through HIPC once the DRC reaches the completion point.

\section{Debt Sustainability Outlook, 2009/10-29/30}

59. The baseline macroeconomic framework assumes a strong recovery in economic activity over the medium term, supported by large investments in mining and public infrastructure projects. The projections are consistent with the medium-term macroeconomic framework under the ECF arrangement and the key assumptions are summarized in Box 3.

\footnotetext{
${ }^{28}$ The EU special initiative provides full debt relief to eligible Least Developed Countries on all outstanding European Development Fund special loans remaining after the full applications of debt relief under the HIPC initiative.
} 


\section{Box 3. The Democratic Republic of the Congo: Key Baseline Macroeconomic Assumptions}

The near-term outlook is dominated by a rebound in world commodity prices (copper in particular) and external demand associated with the global economic recovery, followed by a strong recovery over the medium term fueled by a US $\$ 3.2$ billion investment in a mining project along with US\$3 billion in investments in public infrastructure projects envisaged under the SCCA. Real GDP growth is projected to increase from 2.8 percent in 2009 to an average rate of 6.8 percent in $2010-15$ and then gradually decline to 4.4 percent in the long run.

Government revenues (excluding grants) are projected to rebound from 17 percent of GDP in 2009 to 20 percent in 2010, and then increase gradually to just under 24 percent over the long term. Meanwhile grants drop sharply from 11.7 percent of GDP in 2009 to 6.6 percent in 2010 and then decline gradually to under 4 percent in the long run.

The current account deficit widens dramatically from 10 percent of GDP in 2009 to over 20 percent in 2010-11, mainly due to a large increase in imported factors used in the mining and public infrastructure projects. The deficit narrows thereafter as mining exports expand and investment-related imports diminish over time, gradually declining below 4 percent of GDP by the end of the 20-year projection horizon. Much of the widening in the current account deficit in 2010-11 is covered by net foreign direct investment (FDI), which increases from 5.7 percent of GDP in 2000 to 8.6 percent in 2011 and then quickly falls back to 5.6 percent in 2013. The surge in FDI inflows reflects foreign investment in a series of mining projects planned over the next few years (notably those financed under the SCCA).

External financing in the short term is dominated by loans disbursed to fund public infrastructure projects under the SCCA, which account for over one half of gross borrowing needs over the period 2010-14. The average grant element of new borrowing rises steadily from 20 percent in 2010-11 to just over 48 percent in 2015-16 and then declines gradually to under 45 percent in the long run.

60. Full delivery of debt relief from all sources at the completion point would reduce the DRC's external public debt burden considerably. At end-2010 the PV of external debt-to-exports indicator would fall from 182.5 percent after traditional debt relief to 57.5 percent with the delivery of the additional debt relief provided by the enhanced HIPC/MDRI Initiatives along with beyond HIPC bilateral assistance, which is below the HIPC threshold of 150 percent (see Table 11).

61. With full delivery of debt relief, the external debt outlook is projected to improve markedly over the long term. The external debt indicators initially worsen over the medium term, but then improve gradually over the longer term 
(see Figure 2 and Table 11). This is mainly due to a public guarantee on external borrowing to finance public infrastructure projects under the SCCA. ${ }^{29,30}$

\section{E. Sensitivity Analysis and Long-Term Debt Sustainability}

62. The external debt-to-exports indicator remains well below the HIPC threshold level under two alternative scenarios: lower export growth and less concessional borrowing terms (see Table 12 and Figure 3). In scenario 1, export values remain at their 2010 levels (zero growth) in 2011-12 compared to a 19 percent expansion in the baseline scenario. In scenario 2 , the average grant element of new borrowing declines to 23 percent by the end of the 20 -year projection period, compared to 45 percent in the baseline. The external debt indicators worsen over the medium term in both alternative scenarios, but improve over the longer term (see Figure 3 and Table 12). The external debt-to-exports indicator remains well below the 150 percent threshold level in both cases.

63. The sensitivity analysis highlights the need for strong and continued efforts to diversify the economy to reduce the risk of adverse shocks and prudent debt management to maintain low debt vulnerabilities. While HIPC, beyond HIPC, and MDRI debt relief substantially reduce the DRC's debt burden, the sensitivity analysis clearly shows that the DRC would remain vulnerable to lower exports and higher borrowing costs than assumed in the baseline scenario. In order to ensure that the new debt remain below the HIPC thresholds, it will be crucial to continue to make progress on structural reforms aimed to promote export growth over the long term, and to limit external borrowing to high concessional sources.

\section{Conclusion}

64. In the view of the staffs of the IMF and the IDA, the DRC has met the requirements established in July 2003 for reaching the completion point under the enhanced HIPC initiative. The authorities introduced the required measures to meet the objectives laid out under the seven triggers and moved decisively to implement reforms in PFM, procurement, governance and debt management. The main elements of the HIPC reform program have therefore been satisfactorily implemented.

65. Revisions to the end-2002 data have resulted in an upward adjustment in the amount of HIPC debt relief.

66. Full delivery of HIPC debt relief, and additional bilateral assistance beyond HIPC and MDRI, would considerably reduce the DRC's external public debt. In end-2009 PV terms, the stock of debt would decline to US\$2,147 million at the completion point.

\footnotetext{
${ }^{29}$ Details of this agreement are outlined in IMF Country Report No. 10/88 (Box 3).

${ }^{30}$ Figure 2 in Appendix II illustrates the implications of removing the public guarantee in the context of the LIC DSA framework.
} 
67. In light of the information above, the staffs of the IMF and IDA recommend that the Executive Directors determine that the DRC has reached the completion point under the enhanced HIPC initiative.

\section{ISSUES FOR DISCUSSION}

68. Executive Directors may wish to consider this report based on the following issues for discussion:

- Completion point. Do Directors agree that the DRC has reached the completion point under the enhanced HIPC Initiative, considering the emphasis in the decision point document on the need to establish a track record of sustained performance?

- Data revision. Do Directors agree with staff's recommendations that the revised amount of HIPC assistance of US\$7,252 million at end-December 2002, PV terms be provided to the DRC?

- Topping up. Do Directors agree with the conclusion that there is no need for topping up?

- Creditor participation. Do Directors agree that the DRC's creditors have given sufficient assurances to irrevocably commit HIPC Initiative assistance to the Congo?

- HIPC assistance from the IMF. Do Directors agree with the upward revision in the IMF HIPC assistance from SDR 228.3 million to SDR 280.3 million?

- $\quad$ MDRI/HIPC debt relief. Do Directors agree that the DRC qualifies for debt relief from the IMF, estimated at about SDR 297.2 million, to be financed from the DRC's HIPC Umbrella account? 
Figure 1. Democratic Republic of the Congo: Composition of the Stock of External Debt by Creditor Group, end-December 2002 and 2009 (in percent)

\section{End December-2002}

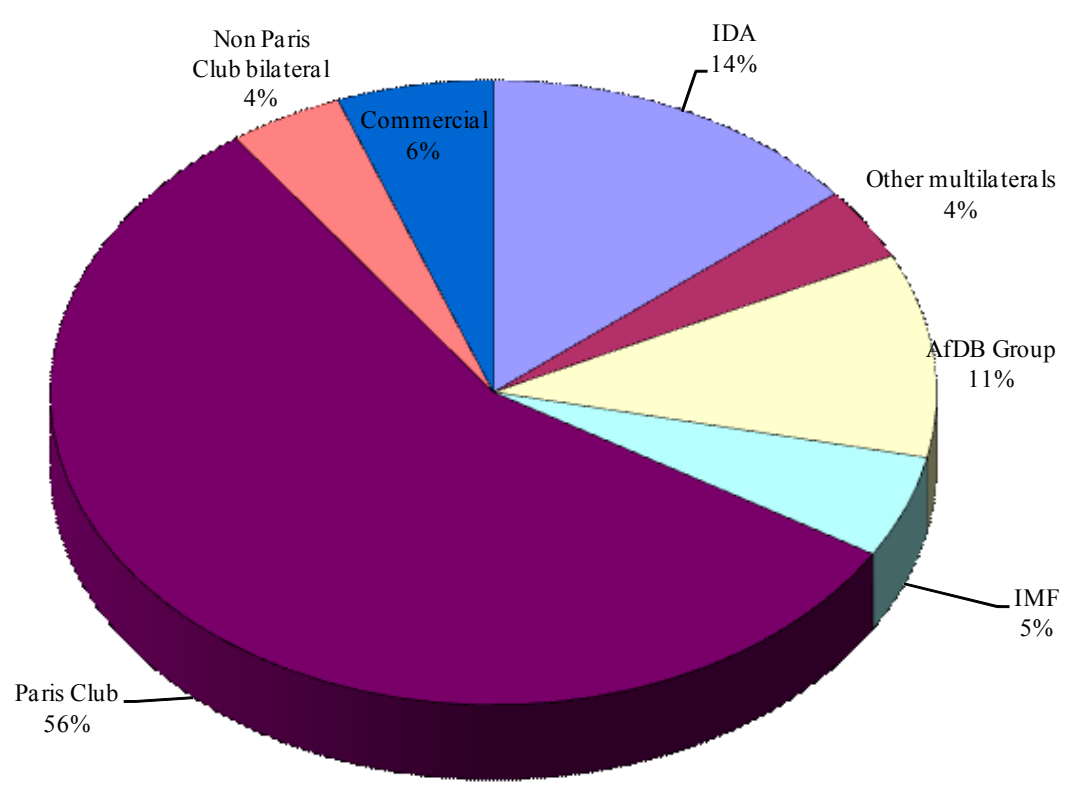

End December-2009

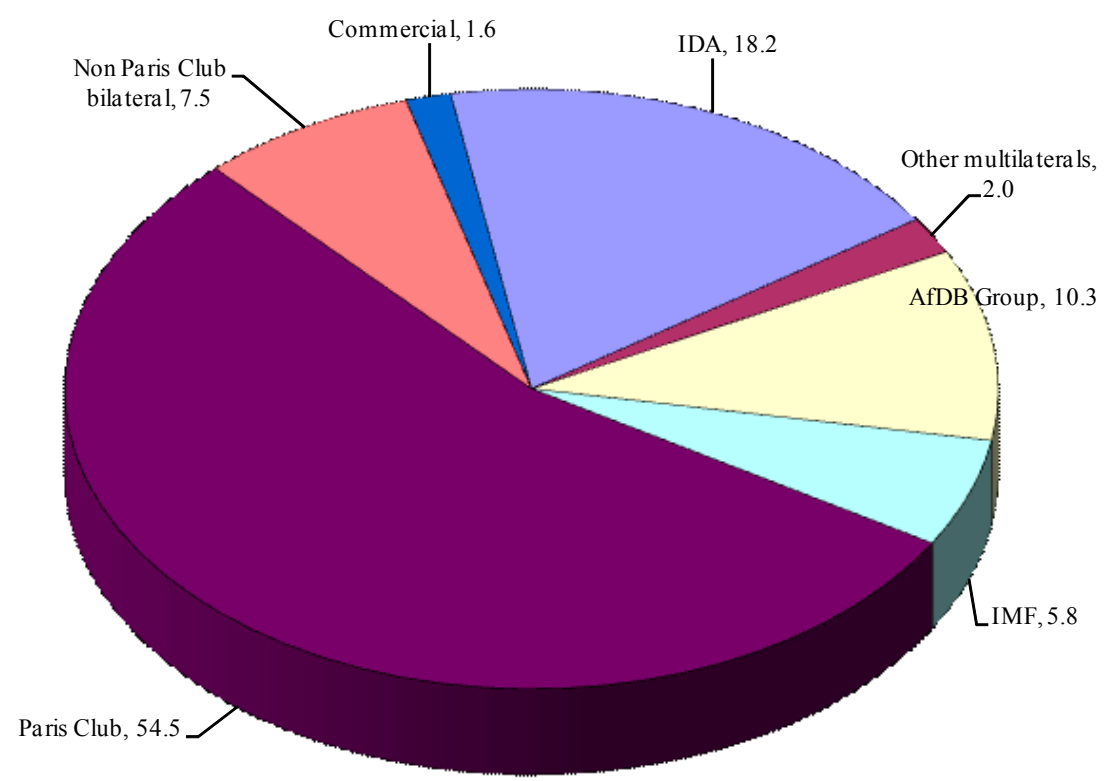

Sources: Congolese authorities; and IMF and World Bank staff estimates. 
Figure 2. Democratic Republic of the Congo: External Debt and Debt Service Indicators for Medium- and Long-Term Public Sector Debt, 2010-30
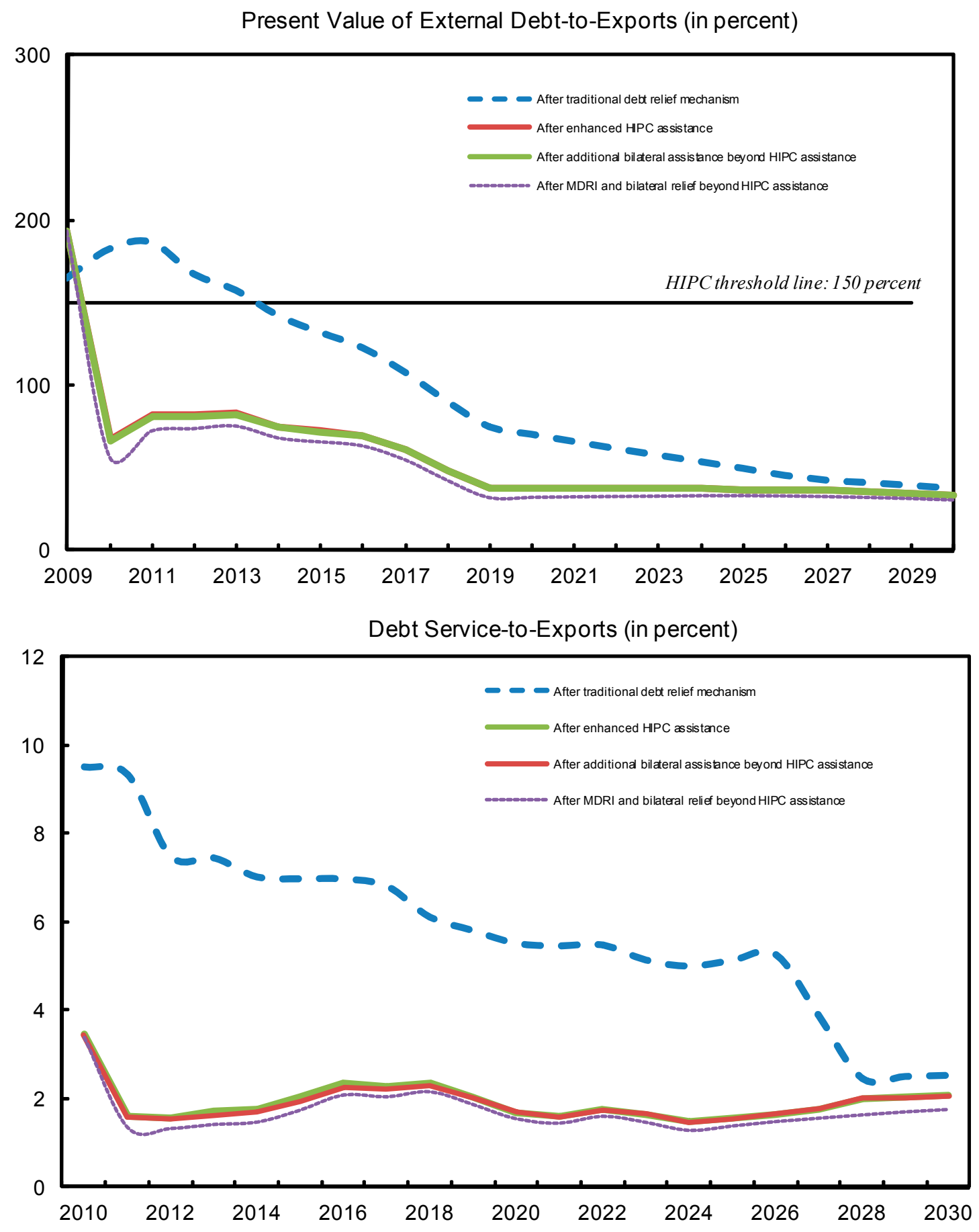

Sources: Congolese authorities; and IMF and World Bank staff estimates. 
Figure 3. Democratic Republic of the Congo: Sensitivity Analysis, 2010-30

Present Value of External Debt-to-exports (in percent)

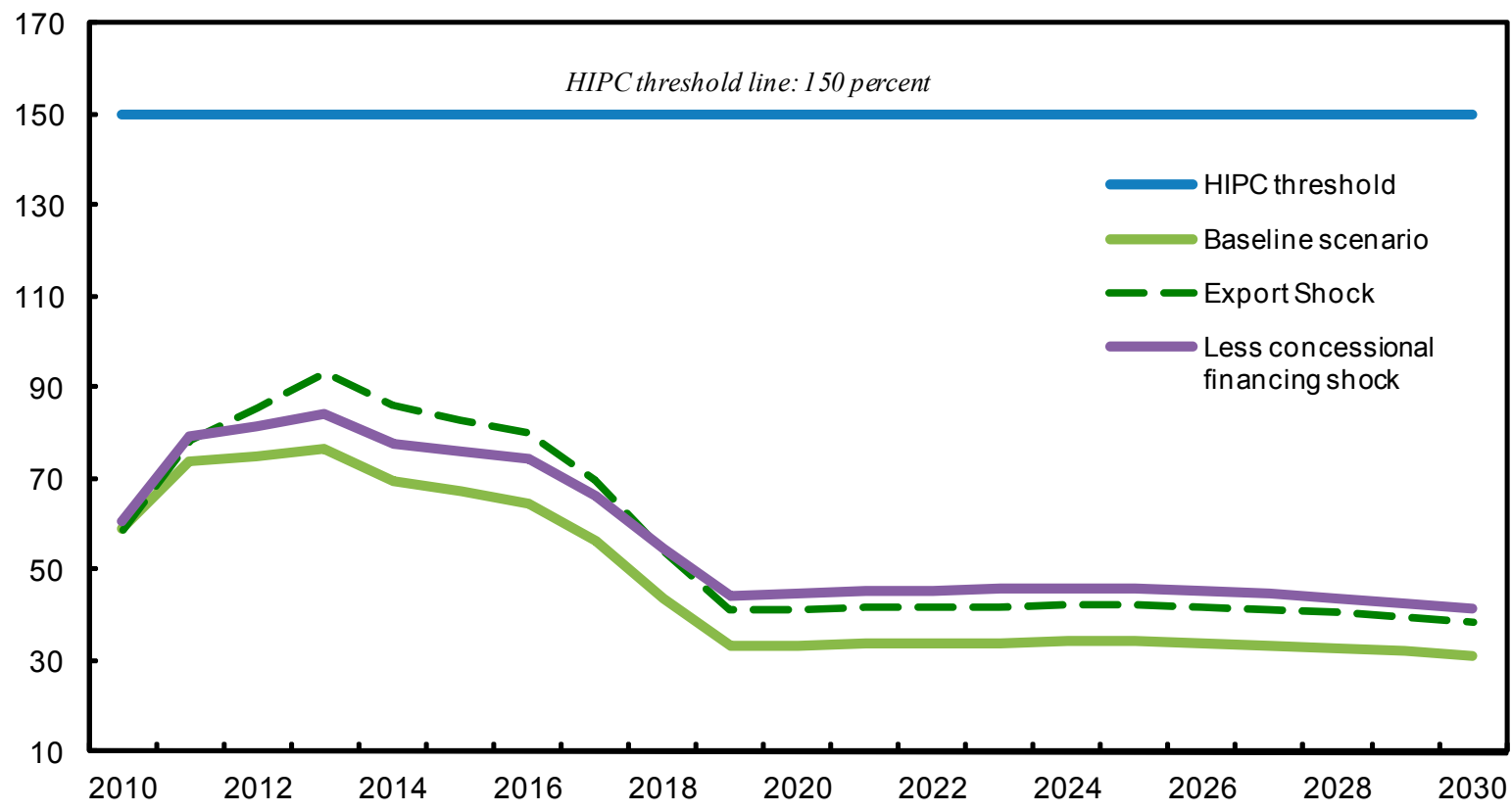

Debt Service-to-exports (in percent)

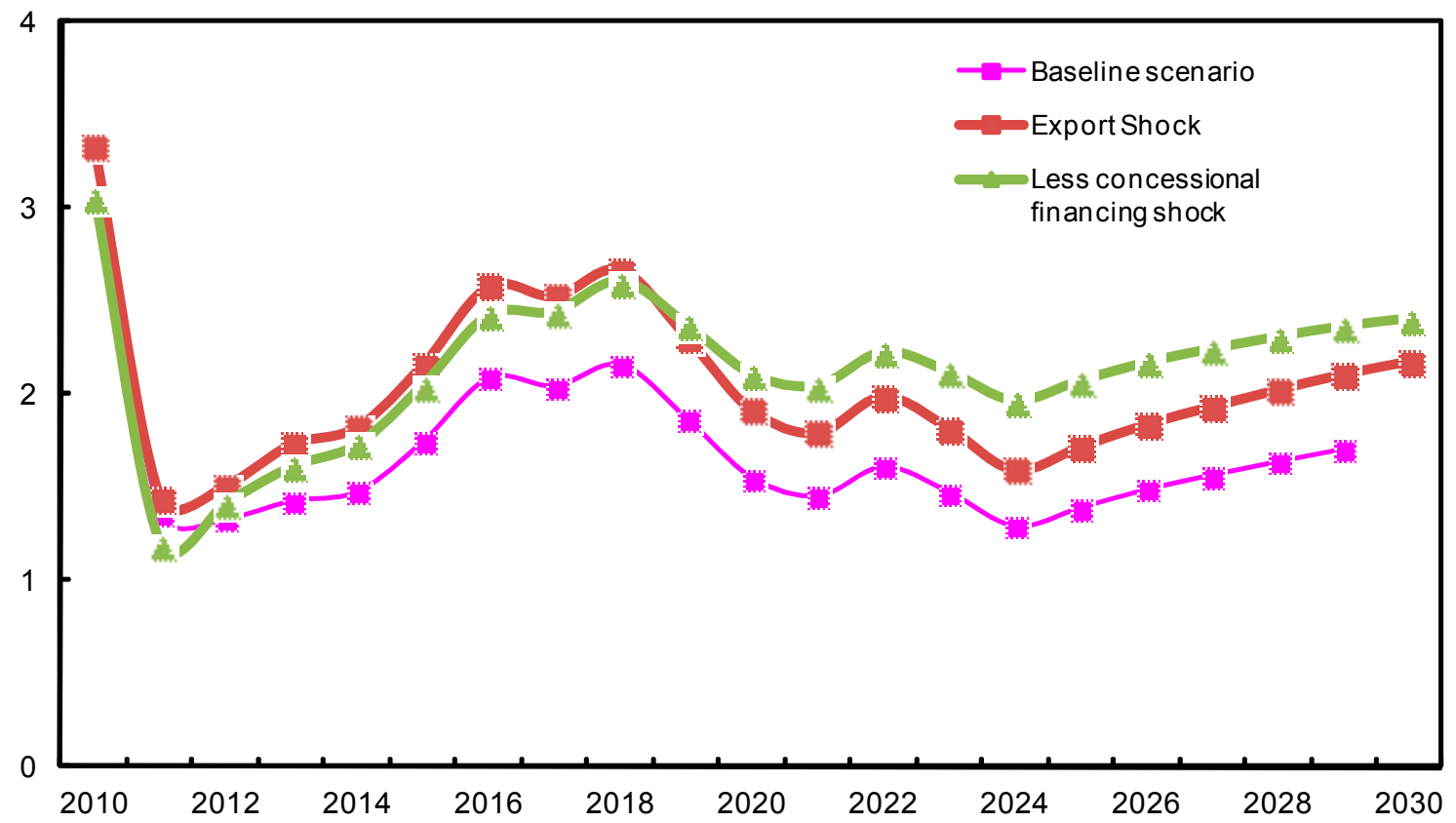

Sources: Congolese auth orities; and IMF and World Bank staff estimates.

1 Zero export growth in 2011-12 than baseline scenario.

2 Less concessional financing terms than baseline scenario. Grant element of new borrowing declines to below 24 percent at 2030 . 
Table 4. Democratic Republic of the Congo: Revised Nominal Stocks and Present Value of Debt at Decision Point by Creditor Groups as of end-December $2002{ }^{1}$

\begin{tabular}{|c|c|c|c|c|c|c|c|c|c|c|c|c|}
\hline & \multicolumn{4}{|c|}{$\begin{array}{c}\text { Nominal Debt Stock } \\
\text { at End-December, } 2002\end{array}$} & \multicolumn{4}{|c|}{ PV of Debt Before Rescheduling ${ }^{2}$} & \multicolumn{4}{|c|}{ PV of Debt After Rescheduling ${ }^{23}$} \\
\hline & \multicolumn{2}{|c|}{ At Decision Point } & \multicolumn{2}{|c|}{$\begin{array}{c}\text { Revised At } \\
\text { Completion Point }\end{array}$} & \multicolumn{2}{|c|}{ At Decision Point } & \multicolumn{2}{|c|}{$\begin{array}{c}\text { Revised At } \\
\text { Completion Point }\end{array}$} & \multicolumn{2}{|c|}{ At Decision Point } & \multicolumn{2}{|c|}{$\begin{array}{c}\text { Revised At } \\
\text { Completion Point }\end{array}$} \\
\hline & $\begin{array}{l}\text { US\$ } \\
\text { million }\end{array}$ & $\begin{array}{c}\text { Percent } \\
\text { of total }\end{array}$ & US\$ million & $\begin{array}{l}\text { Percent } \\
\text { of total }\end{array}$ & $\begin{array}{l}\text { US\$ } \\
\text { million }\end{array}$ & $\begin{array}{l}\text { Percent } \\
\text { of total }\end{array}$ & $\begin{array}{l}\text { US\$ } \\
\text { million }\end{array}$ & $\begin{array}{l}\text { Percent } \\
\text { of total }\end{array}$ & $\begin{array}{l}\text { US\$ } \\
\text { million }\end{array}$ & $\begin{array}{l}\text { Percent } \\
\text { of total }\end{array}$ & $\begin{array}{l}\text { US\$ } \\
\text { million }\end{array}$ & $\begin{array}{l}\text { Percent } \\
\text { of total }\end{array}$ \\
\hline Total & $10,659.0$ & 100 & 10,772 & 100 & 8,404 & 100 & 9,638 & 100 & 7,868 & 100 & 8,801 & 100 \\
\hline Multilateral & 3,580 & 34 & 3,626 & 34 & 3,077 & 37 & 3,196 & 33 & 3,077 & 39 & 3,196 & 36 \\
\hline IDA & 1,512 & 14 & 1,511 & 14 & 1,037 & 12 & 1,036 & 11 & 1,037 & 13 & 1,036 & 12 \\
\hline AfDB Group & 1,136 & 11 & 1,138 & 11 & 1,128 & 13 & 1,225 & 13 & 1,128 & 14 & 1,225 & 14 \\
\hline IMF & 571 & 5 & 571 & 5 & 588 & 7 & 572 & 6 & 588 & 7 & 572 & 7 \\
\hline European Investment Bank & 25 & 0 & 25 & 0 & 25 & 0 & 25 & 0 & 25 & 0 & 25 & 0 \\
\hline European Union & 205 & 2 & 206 & 2 & 170 & 2 & 170 & 2 & 170 & 2 & 170 & 2 \\
\hline IFAD & 28 & 0 & 27 & 0 & 22 & 0 & 20 & 0 & 22 & 0 & 20 & 0 \\
\hline IFC & 30 & 0 & 30 & 0 & 30 & 0 & 30 & 0 & 30 & 0 & 30 & 0 \\
\hline OPEC Fund & 1 & 0 & 1 & 0 & 1 & 0 & 1 & 0 & 1 & 0 & 1 & 0 \\
\hline BDEGL & 8 & 0 & 52 & 0 & 8 & 0 & 52 & 1 & 8 & 0 & 52 & 1 \\
\hline BEAC & 43 & 0 & 43 & 0 & 46 & 1 & 42 & 0 & 46 & 1 & 42 & 0 \\
\hline Official bilateral and commercial & 7,079 & 66 & 7,146 & 66 & 5,328 & 63 & 6,442 & 67 & 4,791 & 61 & 5,605 & 64 \\
\hline Paris Club & 6,363 & 60 & 6,082 & 56 & 4,616 & 55 & 5,385 & 56 & 4,318 & 55 & 4,944 & 56 \\
\hline Pre-cutoff date & 5,293 & 50 & 5,100 & 47 & 3,709 & 44 & 4,535 & 47 & 3,410 & 43 & 4,095 & 47 \\
\hline ODA & 805 & 8 & 1,205 & 11 & 538 & 6 & 922 & 10 & 378 & 5 & 874 & 10 \\
\hline Non-ODA & 4,488 & 42 & 3,895 & 36 & 3,171 & 38 & 3,612 & 37 & 3,033 & 39 & 3,221 & 37 \\
\hline Post-cutoff date & 1,070 & 10 & 982 & 9 & 907 & 11 & 850 & 9 & 907 & 12 & 849 & 10 \\
\hline \multicolumn{13}{|l|}{ by country: } \\
\hline Austria & 97 & 1 & 94 & 1 & 44 & 1 & 44 & 0 & 44 & 1 & 44 & 1 \\
\hline Belgium & 1,361 & 13 & 760 & 7 & 591 & 7 & 708 & 7 & 523 & 7 & 595 & 7 \\
\hline Brazil & 2 & 0 & 2 & 0 & 1 & 0 & 1 & 0 & 1 & 0 & 1 & 0 \\
\hline Canada & 31 & 0 & 29 & 0 & 23 & 0 & 25 & 0 & 23 & 0 & 25 & 0 \\
\hline France & 1,075 & $10^{r}$ & 1,160 & 11 & 866 & 10 & 1,010 & 10 & 866 & 11 & 1,010 & 11 \\
\hline Germany & 415 & 4 & 472 & 4 & 337 & 4 & 432 & 4 & 334 & 4 & 431 & 5 \\
\hline Norway & 19 & 0 & 19 & 0 & 10 & 0 & 11 & 0 & 10 & 0 & 11 & 0 \\
\hline Spain & 18 & 0 & 18 & 0 & 16 & 0 & 16 & 0 & 16 & 0 & 16 & 0 \\
\hline Sweden & 116 & 1 & 117 & 1 & 67 & 1 & 86 & 1 & 55 & 1 & 68 & 1 \\
\hline Switzerland & 11 & 0 & 10 & 0 & 10 & 0 & 10 & 0 & 10 & 0 & 10 & 0 \\
\hline United Kingdom & 123 & 1 & 119 & 1 & 94 & 1 & 100 & 1 & 94 & 1 & 100 & 1 \\
\hline United States & 1,575 & 15 & 1,669 & 15 & 1,310 & 16 & 1,555 & 16 & 1,161 & 15 & 1,323 & 15 \\
\hline EU administered by IDA ${ }^{4}$ & 10 & 0 & 10 & 0 & 8 & 0 & 6 & 0 & 8 & 0 & 3 & 0 \\
\hline Non Paris Club bilateral & 437 & 4 & 448 & 4 & 433 & 5 & 442 & 5 & 274 & 3 & 278 & 3 \\
\hline Burundi & 4 & 0 & 4 & 0 & 4 & 0 & 4 & 0 & 1 & 0 & 1 & 0 \\
\hline China & 39 & 0 & 39 & 0 & 35 & 0 & 35 & 0 & 34 & 0 & 33 & 0 \\
\hline Egypt & 9 & 0 & 9 & 0 & 9 & 0 & 9 & 0 & 9 & 0 & 9 & 0 \\
\hline Is rael & 18 & 0 & 18 & 0 & 18 & 0 & 18 & 0 & 18 & 0 & 17 & 0 \\
\hline Kuwait & 95 & 1 & 98 & 1 & 95 & 1 & 96 & 1 & 41 & 1 & 42 & 0 \\
\hline Namibia & 2 & 0 & 2 & 0 & 2 & 0 & 2 & 0 & 1 & 0 & 1 & 0 \\
\hline Romania & - & - & 2 & 0 & - & - & 2 & 0 & - & - & 2 & 0 \\
\hline Rwanda & 1 & 0 & 1 & 0 & 1 & 0 & 1 & 0 & 0 & 0 & 0 & 0 \\
\hline Saudi Arabia & 28 & 0 & 28 & 0 & 28 & 0 & 28 & 0 & 19 & 0 & 19 & 0 \\
\hline Serbia and Montenegro & 48 & 0 & 40 & 0 & 48 & 1 & 40 & 0 & 37 & 0 & 32 & 0 \\
\hline Taiwan, Province of China & 37 & 0 & 38 & 0 & 36 & 0 & 37 & 0 & 36 & 0 & 37 & 0 \\
\hline United Arab Emirates & 155 & 1 & 171 & 2 & 155 & 2 & 171 & 2 & 77 & 1 & 85 & 1 \\
\hline Commercial & 279 & 3 & 616 & 6 & 279 & 3 & 615 & 6 & 200 & 3 & 383 & 4 \\
\hline of which: London Club ${ }^{5}$ & 58 & 1 & 67 & 1 & 58 & 1 & 67 & 1 & 19 & 0 & 22 & 0 \\
\hline
\end{tabular}

${ }^{1}$ Information based on end-December 2002 data available at completion point after implementing the September 2002 Paris Club agreement.

2 Includes a stock-of-debt operation on Naples terms at end-December 2002; and comparable action by other official bilateral creditors on eligible debt (precutoff and non-ODA).

${ }^{3}$ The increase in the PV of debt for the official bilateral creditors depends on the better documentation available at completion point

${ }^{4}$ Claims from the European Union loan administered by IDA has been removed from the multilateral section at decision point and now included under bilateral d $\epsilon$

${ }^{5}$ Indicates claims of the creditors of the London Club excluding Belgolaise. For more information please refer to the box 2. 
Table 5. Democratic Republic of the Congo: Estimated Assistance at Decision Point (Amended)

(In millions of U.S. dollars in end-December 2002 PV terms, unless otherwise indicated)

\begin{tabular}{|c|c|c|c|c|c|}
\hline & Total & Multilaterals & Bilaterals & Commercial & $\begin{array}{r}\text { Common } \\
\text { Reduction } \\
\text { Factor }^{3} \\
\text { (Percent) }\end{array}$ \\
\hline PV of debt-to-exports target (in percent) & 150 & & & & \\
\hline Assistance (decision point document) & 6,311 & 2,468 & 3,683 & 161 & 80.21 \\
\hline Assistance (revised) & 7,252 & 2,633 & 4,303 & 315 & 82.40 \\
\hline \multicolumn{6}{|l|}{ Memorandum items: } \\
\hline Revised PV of debt at end- 2002 & 8,801 & 3,196 & 5,222 & 383 & \\
\hline Three-year average of exporťs & 1,033 & & & & \\
\hline Revised PV of debt-to-exports ratio (percen€) & 852 & & & & \\
\hline
\end{tabular}

Sources: Congolese authorities; and IMF and World Bank staff estimates and projections.

${ }^{1}$ Assumes proportional burden-sharing as described in "HIPC Initiative: Estimated Costs and Burden-Sharing Approaches"

(www.imf.org, and IDA/SEC M97-306; 7/7/97), that is, after full application of traditional debt relief mechanisms.

${ }^{2}$ Using six-month backward-looking discount rates at end-December 2002 and end-December 2002 exchange rates.

${ }^{3}$ Each creditor's PV reduction in percent of its exposure at the decision point (after hypothetical Naples stock at the end of the base year).

${ }^{4}$ Includes traditional debt relief; a hypothetical stock-of-debt on Naples terms with comparable treatment from non Paris Club creditors.

${ }^{5}$ Goods and service exports, as defined in IMF, Balance of Payments Manual, 5th edition, 1993.

${ }^{6}$ After a hypothetical stock-of-debt operation on Naples terms at end December-2002. 
Table 6. Democratic Republic of the Congo: Comparison of Discount Rate and Exchange Rate Assumptions

\begin{tabular}{|c|c|c|c|c|}
\hline & \multicolumn{2}{|c|}{$\begin{array}{c}\text { Discount Rates }{ }^{12} \\
\text { (in percent per annum) }\end{array}$} & \multicolumn{2}{|c|}{$\begin{array}{c}\text { Exchange Rates }{ }^{3} \\
\text { (Currency per U.S. dollar ) }\end{array}$} \\
\hline & $\begin{array}{l}\text { At decision point } \\
\text { end-December } 2002\end{array}$ & $\begin{array}{l}\text { At completion point } \\
\text { end-December } 2009\end{array}$ & $\begin{array}{l}\text { At decision point } \\
\text { end-December } 2002\end{array}$ & $\begin{array}{l}\text { At completion point } \\
\text { end-December } 2009\end{array}$ \\
\hline \multicolumn{5}{|l|}{ Currency } \\
\hline Austrian Schillings & 5.547 & 4.305 & 13.121 & 9.552 \\
\hline Belgian Franc & 5.547 & 4.305 & 38.467 & 28.002 \\
\hline Canadian Dollar & 5.877 & 3.785 & 1.580 & 1.047 \\
\hline CFA Franc & 5.547 & 4.305 & 625.495 & 902.660 \\
\hline Swiss Franc & 3.415 & 2.847 & 1.387 & 1.031 \\
\hline Chinese Yuan & 4.818 & 3.911 & 8.277 & 6.828 \\
\hline Deutsche Mark & 5.547 & 4.305 & 1.865 & 1.358 \\
\hline Danish Kroner & 5.775 & 4.565 & 7.082 & 5.190 \\
\hline European Currency Unit & 5.547 & 4.305 & 0.954 & 0.694 \\
\hline Spanish Peseta & 5.547 & 4.305 & 158.659 & 115.498 \\
\hline Finnish Markaa & 5.547 & 4.305 & 5.670 & 4.127 \\
\hline French Franc & 5.547 & 4.305 & 6.255 & 4.553 \\
\hline Great Britain Sterling & 5.838 & 4.225 & 0.620 & 0.617 \\
\hline Irish Punt & 5.547 & 4.305 & 0.751 & 0.547 \\
\hline Italian Lira & 5.547 & 4.305 & $1,846.353$ & $1,344.072$ \\
\hline Japanese Yen & 1.753 & 1.972 & 119.900 & 92.060 \\
\hline Kuwaiti Dinar & 4.818 & 3.911 & 0.300 & 0.287 \\
\hline Luxembourg Franc & 5.672 & 4.305 & 38.467 & 28.002 \\
\hline Namibian Dollar & 5.120 & 3.911 & 11.800 & 7.380 \\
\hline Netherland Guilders & 5.672 & 4.305 & 2.101 & 1.530 \\
\hline Norwegian Kroner & 7.763 & 4.445 & 6.966 & 5.780 \\
\hline Portuguese Escudo & 5.547 & 4.305 & 191.172 & 139.166 \\
\hline Saudi Arabia Ryal & 4.818 & 3.911 & 3.745 & 3.750 \\
\hline Special Drawing Rights & 4.818 & 3.911 & 0.736 & 0.638 \\
\hline Swedish Kroner & 6.113 & 4.440 & 8.825 & 7.117 \\
\hline United Arab Emirates Dhirams & 4.818 & 3.911 & 3.673 & 3.673 \\
\hline United States Dollar & 5.120 & 4.085 & 1.000 & 1.000 \\
\hline
\end{tabular}

Memorandum item:

Paris Club cutoff date

June 30,1983

Sources: European Central Bank; IMF, International Financial Statistics; OECD; and staff estimates.

${ }^{1}$ The discount rates used are the average commercial interest reference rates (CIRRs) for the respective currencies over the six-month period ending in December 2009 for the completion point and in December 2002 for the decision point.

${ }^{2}$ For all Euro area currencies, the Euro CIRR is used. For all currencies for which the CIRRs are not available, the SDR discount rate is used as a proxy.

${ }^{3}$ End-of-period exchange rates. 
Table 7. Democratic Republic of the Congo: Status of Creditor Participation Under the Enhanced HIPC Initiative

\begin{tabular}{|c|c|c|c|}
\hline $\begin{array}{c}\text { Debt Relief } \\
\text { in PV } \\
\text { Terms } \\
\text { (US\$ mil.) }\end{array}$ & $\begin{array}{l}\text { Percentage } \\
\text { of Total } \\
\text { Assistance }\end{array}$ & $\begin{array}{l}\text { Satis factory } \\
\text { Reply to } \\
\text { Participate } \\
\text { in Initiative }\end{array}$ & Modalities to Deliver Debt Relief \\
\hline
\end{tabular}

\begin{tabular}{|c|c|c|c|c|}
\hline IDA & 854.0 & 11.8 & yes & $\begin{array}{l}\text { Debt relief delivered through the clearance of arrears and } \\
\text { debt service reduction during the interim period amounts to } \\
\text { US } \$ 442.7 \text { million in decision point } P V \text { terms or } 52 \text { percent of } \\
\text { total HIPC relief estimated at the decision point. IDA is } \\
\text { assumed to provide the remaining amount of relief through a } \\
90 \text { percent reduction of DRC's debt service to IDA through } \\
\text { November } 2027 \text {. }\end{array}$ \\
\hline AfDB Group & 1009.7 & 13.9 & yes & $\begin{array}{l}\text { Debt relief amounting to US } \$ 571.6 \text { million or } 57 \text { percent of } \\
\text { AfDB Group's total debt relief has been delivered through the } \\
\text { restructuring of arrears at decision point and debt service } \\
\text { reduction during the interim period. The remainder of the } \\
\text { AfDB Group's HIPC relief is assumed to be delivered through } \\
\text { a } 80 \text { percent reduction of DRC's debt service from } \\
\text { completion point until July } 2022 \text {. }\end{array}$ \\
\hline IMF & 471.5 & 6.5 & yes & $\begin{array}{l}\text { Debt relief amounting to SDR } 106.3 \text { million in decision point } \\
\text { PV terms has been given in the form of SDR } 49.1 \text { million in } \\
\text { interim assistance on debt service and SDR } 57.2 \text { million } \\
\text { embedded in the grant element associated with } \\
\text { disbursement of the PRGF loan following arrears clearance } \\
\text { at decision point. At completion point, the IMF will provide the } \\
\text { remaining HIPC assistance, amounting to SDR } 231.2 \text { million } \\
\text { in PV terms. }\end{array}$ \\
\hline European Investment Bank & 20.8 & 0.3 & yes & $\begin{array}{l}\text { A conditional debt forgiveness agreement is in place } \\
\text { providing for the recovery of the DRC's debt through partial } \\
\text { relief by the EIB via the latter's HIPC contribution and the } \\
\text { payment of the balance without interest by the DRC over a } \\
\text { period of five years. Debt relief in the form of an interest } \\
\text { moratorium was also provided during the interim period. }\end{array}$ \\
\hline European Union & 140.4 & 1.9 & yes & $\begin{array}{l}\text { Interim assistance amounting to US } \$ 25.1 \text { million in decision } \\
\text { point PV terms has been provided through } 100 \text { percent debt } \\
\text { service reduction on selected loans during the interim period. } \\
\text { Arrears clearance of } \$ 110.8 \text { million in } P V \text { terms was also } \\
\text { provided at decision point on grant terms. The remainder of } \\
\text { HIPC assistance will be delivered through a } 100 \text { percent } \\
\text { cancellation of future debt service on selected loans at } \\
\text { completion point until the HIPC assistance target is met. }\end{array}$ \\
\hline IFAD & 16.3 & 0.2 & yes & $\begin{array}{l}\text { Assistance of US } \$ 1.2 \text { million has been delivered in decision } \\
\text { point PV terms during the interim period in the form of a } \\
\text { donor funded grant paying } 100 \text { percent of debt service on } \\
\text { current maturities during } 2003 \text { as well as arrears } \\
\text { restructuring arrangements. Remaining assistance will be } \\
\text { delivered at the completion point through a } 100 \text { percent } \\
\text { reduction of debt service payments on eligible debt until the } \\
\text { target in PV terms is reached. IFAD is also expected to deliver } \\
\text { debt relief through a concessional treatment of DRC arrears. }\end{array}$ \\
\hline IFC & 24.7 & 0.3 & yes & $\begin{array}{l}\text { During the interim period IFC settled its arrears with the DRC } \\
\text { at terms that met its targeted HIPC relief. }\end{array}$ \\
\hline BADEA & 17.9 & 0.2 & yes & $\begin{array}{l}\text { BADEA agreed in January } 2003 \text { on an arrangement to } \\
\text { reschedule outs tanding arrears, which was amended in } \\
\text { March } 2007 \text {. BADEA provided relief of US } \$ .2 \text { million in } \\
\text { decision point PV terms as a result of this rescheduling. }\end{array}$ \\
\hline OPEC Fund & 0.6 & 0.0 & yes & $\begin{array}{l}\text { The OPEC Fund has agreed to provide debt relief at the } \\
\text { completion point. }\end{array}$ \\
\hline BDEGL & 43.1 & 0.6 & no & $\begin{array}{l}\text { BDEGL has not committed to providing HIPC relief; however, } \\
\text { negotiations are ongoing with the Congolese authorities. }\end{array}$ \\
\hline BEAC & 34.5 & 0.5 & no & $\begin{array}{l}\text { Relief of US } \$ 2.8 \text { million in decision point PV terms was } \\
\text { delivered through arrears restructuring in January } 2001 \text { and } \\
\text { January } 2004 .\end{array}$ \\
\hline Total multilateral & 2633.5 & 36.3 & & \\
\hline Paris Club creditors & 4073.6 & 56.2 & yes & $\begin{array}{l}\text { Paris Club creditors will provide relief based on Cologne } \\
\text { terms. Switzerland has cancelled } 100 \% \text { of its claims in } 2003 .\end{array}$ \\
\hline Non-Paris Club creditors ${ }^{21}$ & 229.0 & 3.2 & & \\
\hline Burundi & 1.1 & 0.0 & no & Negotiations ongoing, no agreement has been signed. \\
\hline China & 27.0 & 0.4 & yes & Cancelled post cut off ODA claims in 2007 \\
\hline Egypt & 7.2 & 0.1 & yes & Cancelled $100 \%$ of claims in 2008 . \\
\hline Israel & 14.4 & 0.2 & yes & Rescheduled its debt in 2007 \\
\hline Kuwait & 34.7 & 0.5 & no & Interest in arrears were cancelled in 2004. \\
\hline Namibia & 0.5 & 0.0 & no & Negotiations ongoing, no agreement has been signed. \\
\hline Romania & 1.3 & 0.0 & yes & Rescheduled its debt in 2005 \\
\hline Rwanda & 0.2 & 0.0 & no & Negotiations ongoing, no agreement has been signed. \\
\hline Saudi Arabia & 16.1 & 0.2 & no & Negotiations ongoing, no agreement has been signed. \\
\hline Serbia and Montenegro & 26.3 & 0.4 & no & Claims were sold to FG Hemis phere. \\
\hline Taiwan, Province of China & 30.5 & 0.4 & no & Negotiations ongoing, no agreement has been signed. \\
\hline United Arab Emirates & 69.8 & 1.0 & no & Negotiations ongoing, no agreement has been signed. \\
\hline Total bilateral & 4302.6 & 59.3 & & \\
\hline Total commercial & 315.5 & 4.4 & & \\
\hline of which: London Club & 18.2 & 0.3 & no & Please refer to Box 2 \\
\hline of which: non-London Club ${ }^{3 /}$ & 297.2 & 4.1 & some & $\begin{array}{l}\text { Several commercial creditors have provided relief in the } \\
\text { interim period. }\end{array}$ \\
\hline Total & 7251.5 & 100.0 & & \\
\hline
\end{tabular}

Sources: Congolese authorities; and IMF and World Bank staff estimates.

1 Under the HIPC Initiative guidelines, a creditor receives credit against the required provision of debt relief for contributions to an arrears clearance operation in a HIPC country.

2 Non-Paris Club creditors holding $0.7 \%$ of the PV of external debt after traditional debt relief have provided HIPC relief

${ }^{3}$ Non-London Club creditors holding approximately $3.9 \%$ of the PV of external debt after traditional debt relief have provided HIPC relief. 
Table 8. Democratic Republic of the Congo: Nominal and Present Value of External Debt Outstanding at End-December $2009^{1}$ (In millions of US\$, unless otherwise indicated)

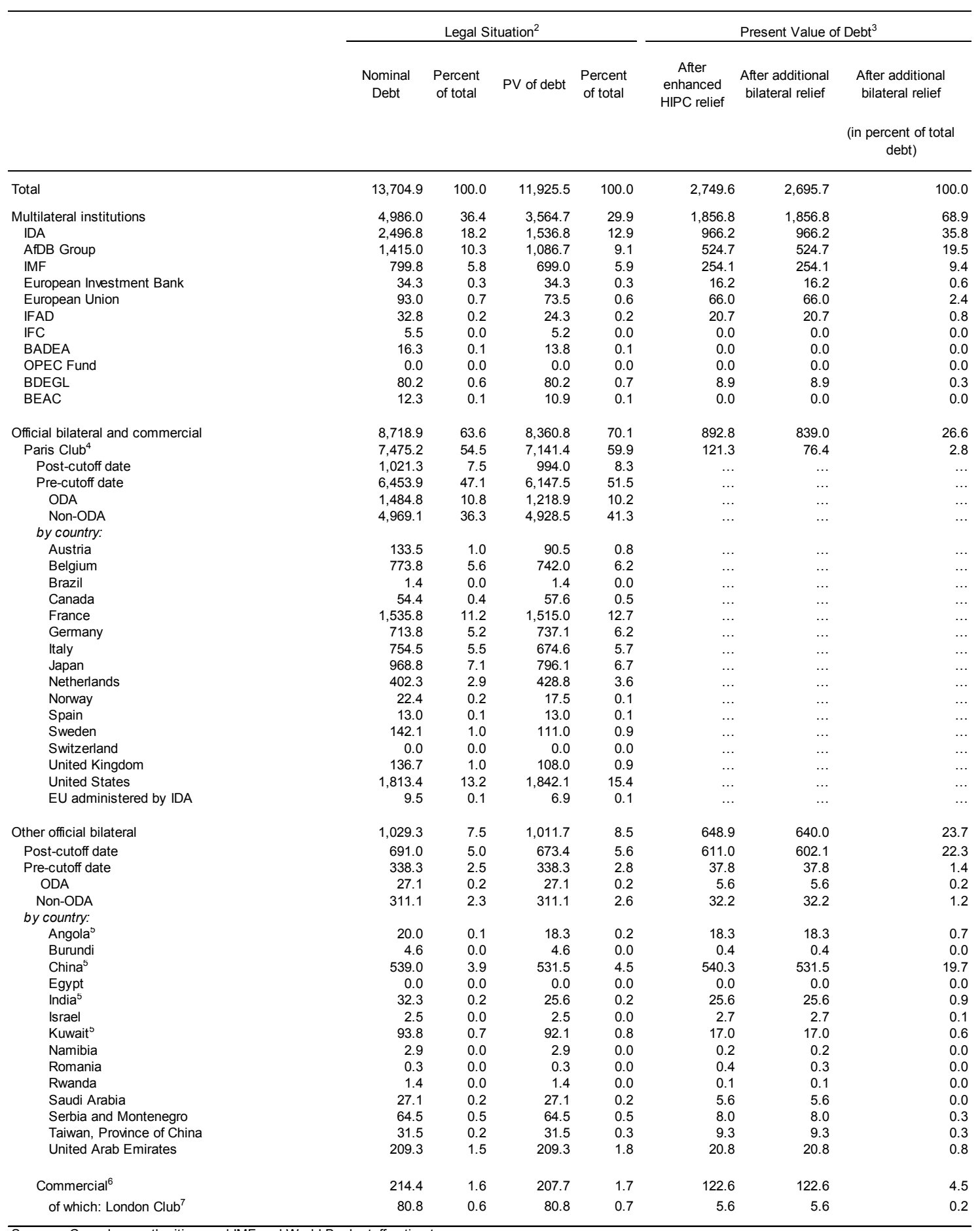

Sources: Congolese authorities; and IMF and World Bank staff estimates.

${ }^{1}$ Information based on latest end December 2009 data available at completion point before signing bilateral agreements referring to the February 2010 Paris Club agreement .

${ }^{2}$ Includes Naples flows, as well as Cologne flow and cancellations in the interim period from Paris Club creditors. The debt stock as of

December 2009 is (based on data available at completion point) before signing bilateral agreements referring to February 2010 Paris Club agreement.

${ }^{3}$ Assumes full delivery of HIPC assistance as of end-December 2009.

${ }^{4}$ Paris Club creditors deliver their share of assistance as a group. Actual delivery modalities are defined on a case-by-case basis.

${ }^{5}$ In the interim period DRC has contracted US $\$ 33.5$ million from India (of which 32.5 has been disbursed), US $\$ 530.5$ million from China, US $\$ 20.0$ million from Angola and US\$ 6.4 million from Kuwait.

${ }^{6}$ HIPC comparable cancellations and reschedulings have been provided by some commercial creditors in the interim period.

' Claims of the London Club based on estimates provided by the authorities. These claims do not include Banque Belgolaise. (See Box 2) 
Table 9. Democratic Republic of the Congo: Present Value of External Debt ${ }^{1}$ (In millions of U.S. dollars, unless otherwise indicated)

\begin{tabular}{|c|c|c|c|c|c|c|c|c|c|}
\hline & Actual & & & & & Projectio & & & \\
\hline & 2009 & 2010 & 2011 & 2012 & 2013 & 2014 & 2019 & 2024 & 2029 \\
\hline I. After traditional debt-relief mechani & & & & & & & & & \\
\hline 1. $\mathrm{PV}$ of total debt $(2+4)$ & 10,263 & 11,698 & 12,713 & 13,516 & 13,997 & 13,512 & 9,797 & 9,224 & 8,683 \\
\hline 2. PV of outstanding debt & 10,263 & 10,010 & 9,720 & 9,458 & 9,134 & 8,430 & 6,488 & 4,134 & 2,202 \\
\hline Official bilateral and commercial & 6,646 & 6,572 & 6,485 & 6,378 & 6,163 & 5,591 & 4,474 & 2,740 & 1,195 \\
\hline Paris Club & 5,371 & 5,312 & 5,241 & 5,155 & 5,050 & 4,956 & 4,168 & 2,497 & 1,054 \\
\hline Other official bilateral & 817 & 802 & 786 & 765 & 720 & 307 & 175 & 135 & 86 \\
\hline Commercial & 458 & 458 & 458 & 457 & 393 & 329 & 131 & 108 & 55 \\
\hline Multilateral & 3,617 & 3,437 & 3,235 & 3,080 & 2,970 & 2,838 & 2,013 & 1,394 & 1,007 \\
\hline IDA & 1,578 & 1,578 & 1,578 & 1,568 & 1,545 & 1,515 & 1,354 & 1,116 & 774 \\
\hline AfDB Group & 1,087 & 1,059 & 1,024 & 979 & 926 & 863 & 483 & 127 & 94 \\
\hline IMF & 699 & 557 & 403 & 309 & 282 & 249 & 0 & 0 & 0 \\
\hline European Investment Bank & 34 & 34 & 34 & 34 & 34 & 34 & 34 & 34 & 34 \\
\hline European Union & 73 & 69 & 64 & 60 & 55 & 50 & 25 & 6 & 0 \\
\hline IFAD & 40 & 40 & 40 & 40 & 41 & 40 & 36 & 30 & 24 \\
\hline $\mathrm{IFC}$ & 0 & 0 & 0 & 0 & 0 & 0 & 0 & 0 & 0 \\
\hline BADEA & 13 & 12 & 11 & 9 & 7 & 6 & 0 & 0 & 0 \\
\hline OPEC Fund & 0 & 0 & 0 & 0 & 0 & 0 & 0 & 0 & 0 \\
\hline BDEGL & 80 & 80 & 80 & 80 & 80 & 80 & 80 & 80 & 80 \\
\hline BEAC & 13 & 6 & 0 & 0 & 0 & 0 & 0 & 0 & 0 \\
\hline II. After enhanced HIPC assistance ${ }^{3}$ & & & & & & & & & \\
\hline 1. $\mathrm{PV}$ of total debt $(2+4)$ & 12,025 & 4,305 & 5,582 & 6,609 & 7,355 & 7,129 & 4,847 & 6,355 & 7,463 \\
\hline 2. PV of outstanding debt & 12,025 & 2,617 & 2,589 & 2,551 & 2,492 & 2,047 & 1,538 & 1,264 & 983 \\
\hline Official bilateral and commercial & 8,625 & 802 & 770 & 739 & 698 & 283 & 159 & 127 & 101 \\
\hline Paris Club & 7,368 & 53 & 51 & 50 & 46 & 37 & 7 & 5 & 2 \\
\hline Other official bilateral & 1,049 & 639 & 626 & 606 & 579 & 182 & 96 & 67 & 45 \\
\hline Commercial & 207 & 111 & 94 & 83 & 73 & 64 & 56 & 55 & 53 \\
\hline Multilateral & 3,400 & 1,814 & 1,819 & 1,812 & 1,794 & 1,764 & 1,378 & 1,138 & 882 \\
\hline IDA & 1,546 & 986 & 1,006 & 1,020 & 1,026 & 1,025 & 1,026 & 987 & 774 \\
\hline AfDB Group & 1,049 & 517 & 503 & 485 & 463 & 437 & 307 & 127 & 94 \\
\hline IMF & 676 & 202 & 207 & 214 & 221 & 228 & 0 & 0 & 0 \\
\hline European Investment Bank & 0 & 13 & 10 & 7 & 4 & 0 & 0 & 0 & 0 \\
\hline European Union & 73 & 67 & 64 & 60 & 55 & 50 & 25 & 6 & 0 \\
\hline IFAD & 31 & 21 & 21 & 22 & 22 & 23 & 20 & 17 & 13 \\
\hline IFC & 0 & 0 & 0 & 0 & 0 & 0 & 0 & 0 & 0 \\
\hline BADEA & 13 & 0 & 0 & 0 & 0 & 0 & 0 & 0 & 0 \\
\hline OPEC Fund & 0 & 0 & 0 & 0 & 0 & 0 & 0 & 0 & 0 \\
\hline BDEGL & 0 & 9 & 7 & 5 & 4 & 2 & 0 & 0 & 0 \\
\hline BEAC & 13 & 0 & 0 & 0 & 0 & 0 & 0 & 0 & 0 \\
\hline 3. $P V$ of total debt after full delivery ${ }^{4}$ & 2,750 & 4,304 & 5,583 & 6,609 & 7,355 & 7,129 & 4,847 & 6,355 & 7,463 \\
\hline Multilateral & 1,857 & 1,814 & 1,819 & 1,812 & 1,794 & 1,764 & 1,378 & 1,138 & 882 \\
\hline Bilateral & 770 & 691 & 677 & 656 & 625 & 219 & 103 & 72 & 48 \\
\hline Commercial & 123 & 111 & 94 & 83 & 73 & 64 & 56 & 55 & 53 \\
\hline As assumed in the decision point & 2,225 & 2,374 & 2,524 & 2,669 & 2,856 & 3,054 & 4,086 & 2,152 & \\
\hline III. After bilateral debt relief beyond $H$ & & & & & & & & & \\
\hline 1. PV of total debt $(2+4)$ & 12,025 & 4,258 & 5,537 & 6,564 & 7,314 & 7,096 & 4,840 & 6,350 & 7,462 \\
\hline 2. PV of outstanding debt & 12,025 & 2,570 & 2,544 & 2,506 & 2,451 & 2,014 & 1,531 & 1,260 & 981 \\
\hline Official bilateral and commercial & 8,625 & 755 & 725 & 694 & 658 & 250 & 153 & 122 & 99 \\
\hline Paris Club & 7,368 & 6 & 6 & 6 & 5 & 4 & 1 & 1 & 0 \\
\hline Other official bilateral & 1,049 & 639 & 626 & 606 & 579 & 182 & 96 & 67 & 45 \\
\hline Commercial & 207 & 111 & 94 & 83 & 73 & 64 & 56 & 55 & 53 \\
\hline Multilateral & 3,400 & 1,814 & 1,819 & 1,812 & 1,794 & 1,764 & 1,378 & 1,138 & 882 \\
\hline IDA & 1,546 & 986 & 1,006 & 1,020 & 1,026 & 1,025 & 1,026 & 987 & 774 \\
\hline AfDB Group & 1,049 & 517 & 503 & 485 & 463 & 437 & 307 & 127 & 94 \\
\hline IMF & 676 & 202 & 207 & 214 & 221 & 228 & 0 & 0 & 0 \\
\hline European Investment Bank & 0 & 13 & 10 & 7 & 4 & 0 & 0 & 0 & 0 \\
\hline European Union & 73 & 67 & 64 & 60 & 55 & 50 & 25 & 6 & 0 \\
\hline IFAD & 31 & 21 & 21 & 22 & 22 & 23 & 20 & 17 & 13 \\
\hline IFC & 0 & 0 & 0 & 0 & 0 & 0 & 0 & 0 & 0 \\
\hline BADEA & 13 & 0 & 0 & 0 & 0 & 0 & 0 & 0 & 0 \\
\hline OPEC Fund & 0 & 0 & 0 & 0 & 0 & 0 & 0 & 0 & 0 \\
\hline BDEGL & 0 & 9 & 7 & 5 & 4 & 2 & 0 & 0 & 0 \\
\hline BEAC & 13 & 0 & 0 & 0 & 0 & 0 & 0 & 0 & 0 \\
\hline 3. $P V$ of total debt after full delivery ${ }^{4}$ & 2,705 & 4,258 & 5,537 & 6,564 & 7,314 & 7,096 & 4,840 & 6,350 & 7,462 \\
\hline Multilateral & 1,857 & 1,814 & 1,819 & 1,812 & 1,794 & 1,764 & 1,378 & 1,138 & 882 \\
\hline Bilateral & 725 & 644 & 632 & 612 & 584 & 186 & 96 & 67 & 46 \\
\hline Commercial & 123 & 111 & 94 & 83 & 73 & 64 & 56 & 55 & 53 \\
\hline IV. After MDRI assistance and bilateral & Issistance & & & & & & & & \\
\hline 1. PV of total debt $(2+4)$ & 12,025 & 3,684 & 4,955 & 5,976 & 6,723 & 6,501 & 4,226 & 5,737 & 6,984 \\
\hline 2. $P V$ of outstanding debt & 12,025 & 1,995 & 1,962 & 1,918 & 1,859 & 1,419 & 917 & 647 & 504 \\
\hline Official bilateral and commercial ${ }^{6}$ & 8,625 & 755 & 725 & 694 & 658 & 250 & 153 & 122 & 99 \\
\hline Multilateral & 3,400 & 1,240 & 1,237 & 1,224 & 1,202 & 1,169 & 764 & 525 & 405 \\
\hline IDA & 1,546 & 500 & 513 & 522 & 525 & 522 & 510 & 465 & 359 \\
\hline AfDB Group & 1,049 & 428 & 413 & 394 & 372 & 344 & 209 & 37 & 32 \\
\hline IMF & 676 & 202 & 207 & 214 & 221 & 228 & 0 & 0 & 0 \\
\hline European Investment Bank & 0 & 13 & 10 & 7 & 4 & 0 & 0 & 0 & 0 \\
\hline European Union & 73 & 67 & 64 & 60 & 55 & 50 & 25 & 6 & 0 \\
\hline IFAD & 31 & 21 & 21 & 22 & 22 & 23 & 20 & 17 & 13 \\
\hline IFC & 0 & 0 & 0 & 0 & 0 & 0 & 0 & 0 & 0 \\
\hline BADEA & 13 & 0 & 0 & 0 & 0 & 0 & 0 & 0 & 0 \\
\hline OPEC Fund & 0 & 0 & 0 & 0 & 0 & 0 & 0 & 0 & 0 \\
\hline BDEGL & 0 & 9 & 7 & 5 & 4 & 2 & 0 & 0 & 0 \\
\hline BEAC & 13 & 0 & 0 & 0 & 0 & 0 & 0 & 0 & 0 \\
\hline 3. $P V$ of total debt after full delivery ${ }^{4}$ & 2,147 & 3,683 & 4,955 & 5,976 & 6,723 & 6,501 & 4,226 & 5,737 & 6,984 \\
\hline Multilateral & 1,299 & 1,240 & 1,237 & 1,224 & 1,202 & 1,169 & 764 & 525 & 405 \\
\hline Bilateral and commercial ${ }^{5}$ & 848 & 755 & 725 & 694 & 658 & 250 & 153 & 122 & 99 \\
\hline andum item: & & & & & & & & & \\
\hline of new borrowing & $\ldots$ & 1,689 & 2,993 & 4,058 & 4,863 & 5,082 & 3,309 & 5,090 & 6,481 \\
\hline
\end{tabular}

${ }^{1}$ Refers to public and publicly guaranteed external debt only and is discounted on the basis of the average commercial interest reference

derived over the six-month period prior to the latest date for which actual data are available (December 2009).

${ }^{2}$ Assumes a stock-of-debt operation on Naples terms (67 percent PV reduction) as of end December-2009, and at least comparable action by other

${ }^{3} \mathrm{PV}$ of debt assuming relief is conditionally delivered in July-2010

${ }^{4} \mathrm{PV}$ of total debt assuming relief is fully delivered as of end December-2009.

${ }^{5}$ Includes additional debt relief provided on a voluntary basis by the Paris Club beyond the requirements of the enhanced HIPC framework as specified on Table 12 .

${ }^{6}$ This corresponds to the situation after additional bilateral relief for Paris Club Creditors. 
Table 10. Democratic Republic of the Congo: External Debt Service After Full Implementation of Debt-Relief Mechanisms (In millions of U.S. dollars, unless otherwise indicated)

\begin{tabular}{|c|c|c|c|c|c|c|c|c|c|c|c|}
\hline & \multirow[b]{2}{*}{2010} & \multirow[b]{2}{*}{2011} & \multirow[b]{2}{*}{2012} & \multirow[b]{2}{*}{2013} & \multirow[b]{2}{*}{2014} & \multirow[b]{2}{*}{2019} & \multirow[b]{2}{*}{2024} & \multirow[b]{2}{*}{2029} & & Annual $A$ & verage \\
\hline & & & & & & & & & 2030 & 2010-2019 & $2020-2030$ \\
\hline After traditional debt-relief mechanism & & & & & & & & & & & \\
\hline Total debt service including new borrowing & 610.9 & 637.9 & 605.1 & 662.9 & 667.6 & 758.1 & 854.2 & 547.9 & 581.1 & 696.3 & 765.4 \\
\hline Total debt senvice on outstanding debt & 607.9 & 633.6 & 595.3 & 647.6 & 647.9 & 623.2 & 684.7 & 222.6 & 223.9 & 646.7 & 548.1 \\
\hline Multilateral & 307 & 322 & 267 & 216 & 235 & 232 & 129 & 114 & 111 & 260.7 & 149.1 \\
\hline IDA & 61.7 & 61.8 & 72.3 & 84.2 & 90.7 & 87.7 & 112.8 & 101.2 & 98.6 & 81.6 & 101.9 \\
\hline AfDB Group & 59.3 & 66.7 & 74.8 & 82.3 & 90.4 & 99.4 & 10.9 & 10.4 & 10.3 & 86.0 & 42.5 \\
\hline European Investment Bank & 0.0 & 0.0 & 0.0 & 0.0 & 0.0 & 0.0 & 0.0 & 0.0 & 0.0 & 0.0 & 0.0 \\
\hline European Union & 7.9 & 7.3 & 7.3 & 7.3 & 7.3 & 6.0 & 3.0 & 0.5 & 0.0 & 7.1 & 2.7 \\
\hline IFAD & 1.0 & 1.1 & 1.1 & 1.1 & 1.4 & 2.1 & 2.1 & 2.0 & 1.7 & 1.6 & 2.0 \\
\hline IFC & 0.0 & 0.0 & 0.0 & 0.0 & 0.0 & 0.0 & 0.0 & 0.0 & 0.0 & $0.0^{*}$ & 0.0 \\
\hline BADEA & 1.2 & 2.3 & 2.1 & 2.1 & 2.1 & 0.0 & 0.0 & 0.0 & 0.0 & 1.6 & 0.0 \\
\hline OPEC Fund & 0.0 & 0.0 & 0.0 & 0.0 & 0.0 & 0.0 & 0.0 & 0.0 & 0.0 & 0.0 & 0.0 \\
\hline BDEGL & 0.0 & 0.0 & 0.0 & 0.0 & 0.0 & 0.0 & 0.0 & 0.0 & 0.0 & 0.0 & 0.0 \\
\hline BEAC & 6.6 & 6.6 & 0.0 & 0.0 & 0.0 & 0.0 & 0.0 & 0.0 & 0.0 & 1.3 & 0.0 \\
\hline Official bilateral & 301.2 & 311.5 & 328.1 & 366.1 & 347.5 & 389.5 & 549.5 & 94.3 & 97.0 & 352.9 & 390.6 \\
\hline Other official bilateral & 30.6 & 30.6 & 36.0 & 58.6 & 55.0 & 14.7 & 11.1 & 15.5 & 16.6 & 38.5 & 13.9 \\
\hline Commercial & 0.0 & 0.0 & 0.0 & 65.2 & 65.2 & 2.1 & 6.5 & 14.2 & 16.3 & 33.1 & 8.4 \\
\hline After enhanced HIPC assistance & & & & & & & & & & & \\
\hline Total debt service including new borrowing & 221.5 & 109.5 & 126.9 & 151.7 & 168.9 & 263.8 & 251.4 & 446.4 & 475.1 & 205.8 & 321.6 \\
\hline Total debt senvice on outstanding debt & 218.4 & 105.1 & 117.1 & 136.4 & 149.3 & 128.9 & 81.9 & 121.0 & 117.9 & 156.2 & 104.3 \\
\hline Multilateral & 110.0 & 61.6 & 73.2 & 84.8 & 95.3 & 117.3 & 75.7 & 113.4 & 110.2 & 110.8 & 96.2 \\
\hline IDA & 18.5 & 18.5 & 25.4 & 33.9 & 40.7 & 39.5 & 60.5 & 101.2 & 98.6 & 33.7 & 66.5 \\
\hline AfDB Group & 22.6 & 29.3 & 33.0 & 36.3 & 39.7 & 34.0 & 10.9 & 10.4 & 10.3 & 34.7 & 25.6 \\
\hline IMF & 61.9 & 2.8 & 1.6 & 1.5 & 1.4 & 36.5 & 0.0 & 0.0 & 0.0 & 32.4 & 0.0 \\
\hline European Investment Bank & 3.7 & 3.7 & 3.7 & 3.7 & 3.7 & 0.0 & 0.0 & 0.0 & 0.0 & 1.8 & 0.0 \\
\hline European Union & 2.2 & 5.1 & 7.3 & 7.3 & 7.3 & 6.0 & 3.0 & 0.5 & 0.0 & 6.3 & 2.7 \\
\hline IFAD & 0.7 & 0.3 & 0.3 & 0.3 & 0.6 & 1.4 & 1.4 & 1.3 & 1.3 & 0.9 & 1.4 \\
\hline IFC & 0.0 & 0.0 & 0.0 & 0.0 & 0.0 & 0.0 & 0.0 & 0.0 & 0.0 & $0.0^{\prime}$ & 0.0 \\
\hline BADEA & 0.0 & 0.0 & 0.0 & 0.0 & 0.0 & 0.0 & 0.0 & 0.0 & 0.0 & 0.0 & 0.0 \\
\hline OPEC Fund & 0.0 & 0.0 & 0.0 & 0.0 & 0.0 & 0.0 & 0.0 & 0.0 & 0.0 & 0.0 & 0.0 \\
\hline BDEGL & 0.5 & 1.9 & 1.9 & 1.9 & 1.9 & 0.0 & 0.0 & 0.0 & 0.0 & 1.0 & 0.0 \\
\hline BEAC & 0.0 & 0.0 & 0.0 & 0.0 & 0.0 & 0.0 & 0.0 & 0.0 & 0.0 & 0.0 & 0.0 \\
\hline Commercial & 15.0 & 19.7 & 12.9 & 10.8 & 10.1 & 0.3 & 0.4 & 0.7 & 0.7 & 7.8 & 0.5 \\
\hline After bilateral debt relief beyond HIPC & & & & & & & & & & & \\
\hline Total debt service including new borrowing & 220.7 & 107.1 & 124.3 & 145.4 & 159.8 & 262.9 & 250.7 & 445.7 & 474.7 & 200.6 & 320.9 \\
\hline Total debt senvice on outstanding debt & 217.6 & 102.7 & 114.5 & 130.1 & 140.2 & 128.1 & 81.2 & 120.4 & 117.5 & 151.1 & 103.6 \\
\hline Multilateral & 110.0 & 61.6 & 73.2 & 84.8 & 95.3 & 117.3 & 75.7 & 113.4 & 110.2 & 110.8 & 96.2 \\
\hline Official bilateral & 92.7 & 21.4 & 28.3 & 34.5 & 34.7 & 10.4 & 5.1 & 6.3 & 6.6 & 32.4 & 7.0 \\
\hline Paris Club & 73.8 & 0.0 & 0.2 & 0.8 & 1.3 & 0.0 & 0.1 & 0.1 & 0.1 & 8.0 & 0.1 \\
\hline Other official bilateral & 18.8 & 21.4 & 28.2 & 33.7 & 33.5 & 10.4 & 5.0 & 6.2 & 6.5 & 24.4 & 6.9 \\
\hline Commercial & 15.0 & 19.7 & 12.9 & 10.8 & 10.1 & 0.3 & 0.4 & 0.7 & 0.7 & 7.8 & 0.5 \\
\hline After MDRI assistance and bilateral deb & ef beyo & d HIPC & issistan & & & & & & & & \\
\hline Total debt service including new borrowing & 216.2 & 92.3 & 107.4 & 126.5 & 140.0 & 243.8 & 219.9 & 373.4 & 404.9 & 183.5 & 280.9 \\
\hline Total debt service on outstanding debt & 213.1 & 87.9 & 97.6 & 111.2 & 120.4 & 108.9 & 50.4 & 48.1 & 47.7 & 133.9 & 63.6 \\
\hline Multilateral & 105 & 47 & 56 & 66 & 75 & 98 & 45 & 41 & 40 & 93.7 & 56.1 \\
\hline IDA & 14.4 & 6.3 & 11.2 & 17.4 & 23.1 & 22.4 & 38.6 & 37.3 & 37.0 & 18.6 & 33.5 \\
\hline AfDB Group & 22.1 & 26.7 & 30.4 & 33.8 & 37.5 & 31.9 & 2.0 & 2.0 & 2.0 & 32.6 & 18.6 \\
\hline IMF & 61.9 & 2.8 & 1.6 & 1.5 & 1.4 & 36.5 & 0.0 & 0.0 & 0.0 & 32.4 & 0.0 \\
\hline European Investment Bank & 3.7 & 3.7 & 3.7 & 3.7 & 3.7 & 0.0 & 0.0 & 0.0 & 0.0 & 1.8 & 0.0 \\
\hline European Union & 2.2 & 5.1 & 7.3 & 7.3 & 7.3 & 6.0 & 3.0 & 0.5 & 0.0 & 6.3 & 2.7 \\
\hline IFAD & 0.7 & 0.3 & 0.3 & 0.3 & 0.6 & 1.4 & 1.4 & 1.3 & 1.3 & 0.9 & 1.4 \\
\hline IFC & 0.0 & 0.0 & 0.0 & 0.0 & 0.0 & 0.0 & 0.0 & 0.0 & 0.0 & 0.0 & 0.0 \\
\hline BADEA & 0.0 & 0.0 & 0.0 & 0.0 & 0.0 & 0.0 & 0.0 & 0.0 & 0.0 & 0.0 & 0.0 \\
\hline OPEC Fund & 0.0 & 0.0 & 0.0 & 0.0 & 0.0 & 0.0 & 0.0 & 0.0 & 0.0 & 0.0 & 0.0 \\
\hline BDEGL & 0.5 & 1.9 & 1.9 & 1.9 & 1.9 & 0.0 & 0.0 & 0.0 & 0.0 & 1.0 & 0.0 \\
\hline BEAC & 0.0 & 0.0 & 0.0 & 0.0 & 0.0 & 0.0 & 0.0 & 0.0 & 0.0 & 0.0 & 0.0 \\
\hline Official bilateral $^{2}$ & 92.7 & 21.4 & 28.3 & 34.5 & 34.7 & 10.4 & 5.1 & 6.3 & 6.6 & 32.4 & 7.0 \\
\hline Commercial & 15.0 & 19.7 & 12.9 & 10.8 & 10.1 & 0.3 & 0.4 & 0.7 & 0.7 & 7.8 & 0.5 \\
\hline Memorandum items: & & & & & & & & & & & \\
\hline Debt service of new borrowing & 3.1 & 4.4 & 9.8 & 15.3 & 19.7 & 134.9 & 169.5 & 325.4 & 357.2 & 49.6 & 217.3 \\
\hline Nominal debt relief & & & & & & & & & & & \\
\hline Under the enhanced HIPC initiative & 389.5 & 528.4 & 478.2 & 511.2 & 498.6 & 494.3 & 602.8 & 101.6 & 106.0 & 490.5 & 443.8 \\
\hline Under the MDRI & 4.5 & 14.8 & 16.8 & 18.9 & 19.8 & 19.1 & 30.8 & 72.3 & 69.8 & 17.2 & 40.0 \\
\hline
\end{tabular}

Sources: Congolese authorities; and IMF and World Bank staff estimates and projections.

${ }^{1}$ Assumes a stock-of-debt operation on Naples terms (67 percent PV reduction) as of end December-2009, and at least comparable action by other official bilateral creditors.

${ }^{2}$ Includes additional debt relief provided on a voluntary basis by the Paris Club beyond the requirements of the enhanced HIPC framework. 
Table 11. Democratic Republic of the Congo: Key External Debt Indicators, 2009-30 ${ }^{1}$

(in percent, unless otherwise indicated)

\begin{tabular}{|c|c|c|c|c|c|c|c|c|c|c|c|c|}
\hline & \multirow{2}{*}{$\frac{\text { Actual }}{2009}$} & \multicolumn{9}{|c|}{ Estımate } & \multicolumn{2}{|c|}{ Annual Averages } \\
\hline & & 2010 & 2011 & 2012 & 2013 & 2014 & 2019 & 2024 & 2029 & 2030 & $\begin{array}{r}2010- \\
2019\end{array}$ & $\begin{array}{r}2020 \\
2030\end{array}$ \\
\hline \multicolumn{13}{|l|}{ After traditional debt relief } \\
\hline PV of debt-to-exports ratio 25 & 165.0 & 182.5 & 186.6 & 167.5 & 157.7 & 142.3 & 75.2 & 54.1 & 39.7 & 37.9 & 136.6 & 51.7 \\
\hline PV of debt-to-exports ratio (existing debt only) 25 & 165.0 & 156.2 & 142.7 & 117.2 & 102.9 & 88.8 & 49.8 & 24.2 & 10.1 & 8.9 & 92.4 & 22.5 \\
\hline PV of debt-to-revenues ratio 5 & 548.8 & 488.5 & 484.5 & 459.2 & 418.3 & 355.2 & 172.6 & 112.7 & 74.6 & 69.7 & 347.2 & 107.0 \\
\hline Debt service-to-export ratio ${ }^{5}$ & $\ldots$ & 8.6 & 7.7 & 6.9 & 7.0 & 6.6 & 5.5 & 4.8 & 2.4 & 2.4 & 6.8 & 4.2 \\
\hline \multicolumn{13}{|l|}{ After enhanced HIPC assistance } \\
\hline PV of debt-to-GDP ratio & 109.7 & 35.3 & 42.3 & 46.4 & 47.3 & 42.3 & 19.6 & 18.1 & 15.1 & 14.3 & 37.0 & 17.3 \\
\hline PV of debt-to-exports ratio 25 & 193.3 & 67.2 & 81.9 & 81.9 & 82.8 & 75.1 & 37.2 & 37.2 & 34.1 & 32.9 & 67.7 & 36.2 \\
\hline PV of debt-to-exports ratio (existing debt only) 25 & 193.3 & 40.8 & 38.0 & 31.6 & 28.1 & 21.6 & 11.8 & 7.4 & 4.5 & 3.9 & 23.5 & 7.1 \\
\hline PV of debt-to-revenues ratio 5 & 642.9 & 179.8 & 212.8 & 224.6 & 219.8 & 187.4 & 85.4 & 77.7 & 64.1 & 60.6 & 171.3 & 74.2 \\
\hline Debt service-to-export ratio ${ }^{5}$ & $\ldots$ & 3.1 & 1.3 & 1.4 & 1.6 & 1.7 & 1.9 & 1.4 & 1.9 & 2.0 & 2.0 & 1.7 \\
\hline Debt service-to-revenue ratio ${ }^{3}$ & $\ldots$ & 9.2 & 4.2 & 4.3 & 4.5 & 4.4 & 4.6 & 3.1 & 3.8 & 3.8 & 5.3 & 3.6 \\
\hline \multicolumn{13}{|l|}{ After additional beyond HIPC bilateral assistance } \\
\hline PV of debt-to-exports ratio 25 & 193.3 & 66.4 & 81.3 & 81.4 & 82.4 & 74.7 & 37.1 & 37.2 & 34.1 & 32.9 & 67.3 & 36.2 \\
\hline PV of debt-to-exports ratio (existing debt only) 25 & 193.3 & 40.1 & 37.3 & 31.1 & 27.6 & 21.2 & 11.7 & 7.4 & 4.5 & 3.9 & 23.2 & 7.0 \\
\hline PV of debt-to-revenues ratio 5 & 642.9 & 177.8 & 211.0 & 223.0 & 218.6 & 186.5 & 85.3 & 77.6 & 64.1 & 60.6 & 170.4 & 74.1 \\
\hline Debt service-to-export ratio ${ }^{5}$ & $\ldots$ & 3.1 & 1.3 & 1.4 & 1.5 & 1.6 & 1.9 & 1.4 & 1.9 & 2.0 & 1.9 & 1.7 \\
\hline Debt service-to-revenue ratio ${ }^{3}$ & $\ldots$ & 9.2 & 4.1 & 4.2 & 4.3 & 4.2 & 4.6 & 3.1 & 3.8 & 3.8 & 5.2 & 3.6 \\
\hline \multicolumn{13}{|l|}{ After MDRI ${ }^{5}$} \\
\hline PV of debt-to-GDP ratio & 109.7 & 30.2 & 37.6 & 41.9 & 43.3 & 38.6 & 17.1 & 16.3 & 14.1 & 13.5 & 33.4 & 15.7 \\
\hline PV of debt-to-exports ratio 25 & 193.3 & 57.5 & 72.7 & 74.1 & 75.7 & 68.5 & 32.4 & 33.6 & 31.9 & 31.1 & 60.9 & 32.9 \\
\hline PV of debt-to-exports ratio (existing debt only) 25 & 193.3 & 31.1 & 28.8 & 23.8 & 20.9 & 14.9 & 7.0 & 3.8 & 2.3 & 2.1 & 16.8 & 3.7 \\
\hline PV of debt-to-revenues ratio 5 & 642.9 & 153.8 & 188.8 & 203.1 & 200.9 & 170.9 & 74.5 & 70.1 & 60.0 & 57.2 & 154.2 & 67.3 \\
\hline Debt service-to-export ratio ${ }^{5}$ & $\ldots$ & 3.0 & 1.1 & 1.2 & 1.3 & 1.4 & 1.8 & 1.2 & 1.6 & 1.7 & 1.7 & 1.5 \\
\hline Debt service-to-revenue ratio ${ }^{3}$ & $\ldots$ & 9.0 & 3.5 & 3.6 & 3.8 & 3.7 & 4.3 & 2.7 & 3.2 & 3.2 & 4.7 & 3.1 \\
\hline Memorandum items: & \multicolumn{12}{|c|}{ (in millions of U.S. dollars) } \\
\hline PV of debt after traditional debt relief & 10,263 & 11,698 & 12,713 & 13,516 & 13,997 & 13,512 & 9,797 & 9,224 & 8,683 & 8,717 & 12,581 & 9,056 \\
\hline Debt service after traditional debt relief & $\ldots$ & 611 & 638 & 605 & 663 & 668 & 758 & 854 & 548 & 581 & 696 & 765 \\
\hline PV of debt after HIPC assistance & 12,025 & 4,305 & 5,582 & 6,609 & 7,355 & 7,129 & 4,847 & 6,355 & 7,463 & 7,572 & 6,371 & 6,524 \\
\hline Debt service after additional bilateral relief & $\ldots$ & 221 & 107 & 124 & 145 & 160 & 263 & 251 & 446 & 475 & 201 & 321 \\
\hline PV of debt after MDRI and additional bilateral relief 4 & 12,025 & 3,684 & 4,955 & 5,976 & 6,723 & 6,501 & 4,226 & 5,737 & 6,984 & 7,144 & 5,747 & 5,945 \\
\hline Debt service after MDRI and additional bilateral relief ${ }^{4}$ & $\ldots$ & 216 & 92 & 107 & 126 & 140 & 244 & 220 & 373 & 405 & 183 & 281 \\
\hline GDP & 10,958 & 12,200 & 13,193 & 14,249 & 15,539 & 16,841 & 24,687 & 35,093 & 49,441 & 52,959 & 17,922 & 38,450 \\
\hline Exports of goods and services ${ }^{5}$ & 5,021 & 7,097 & 8,322 & 8,782 & 9,528 & 10,170 & 13,763 & 17,937 & 22,977 & 24,121 & 10,550 & 19,053 \\
\hline Exports of goods and services (3-year mvg. avg.) ${ }^{25}$ & 6,221 & 6,409 & 6,814 & 8,067 & 8,878 & 9,494 & 13,037 & 17,060 & 21,897 & 22,993 & 9,771 & 18,123 \\
\hline Government revenue $^{3}$ & 1,870 & 2,395 & 2,624 & 2,943 & 3,347 & 3,804 & 5,675 & 8,183 & 11,645 & 12,500 & 3,956 & 8,993 \\
\hline
\end{tabular}

${ }^{1}$ All debt indicators refer to public and publicly guaranteed (PPG) debt and are defined after rescheduling, unless otherwise indicated.

${ }^{2}$ Based on a three-year average of exports on the previous year (e.g., export average over 2005-07 for PV of debt-to-exports ratio in 2007).

${ }^{3}$ Revenues are defined as central government revenues, excluding grants

${ }^{4}$ Assumes delivery of MDRI relief.

${ }^{5}$ As defined in IMF, Balance of Payments Manual, 5th edition, 1993. 
Table 12. Democratic Republic of the Congo: Sensitivity Analysis, 2010-30 ${ }^{1}$

(In percent, unless otherwise indicated)

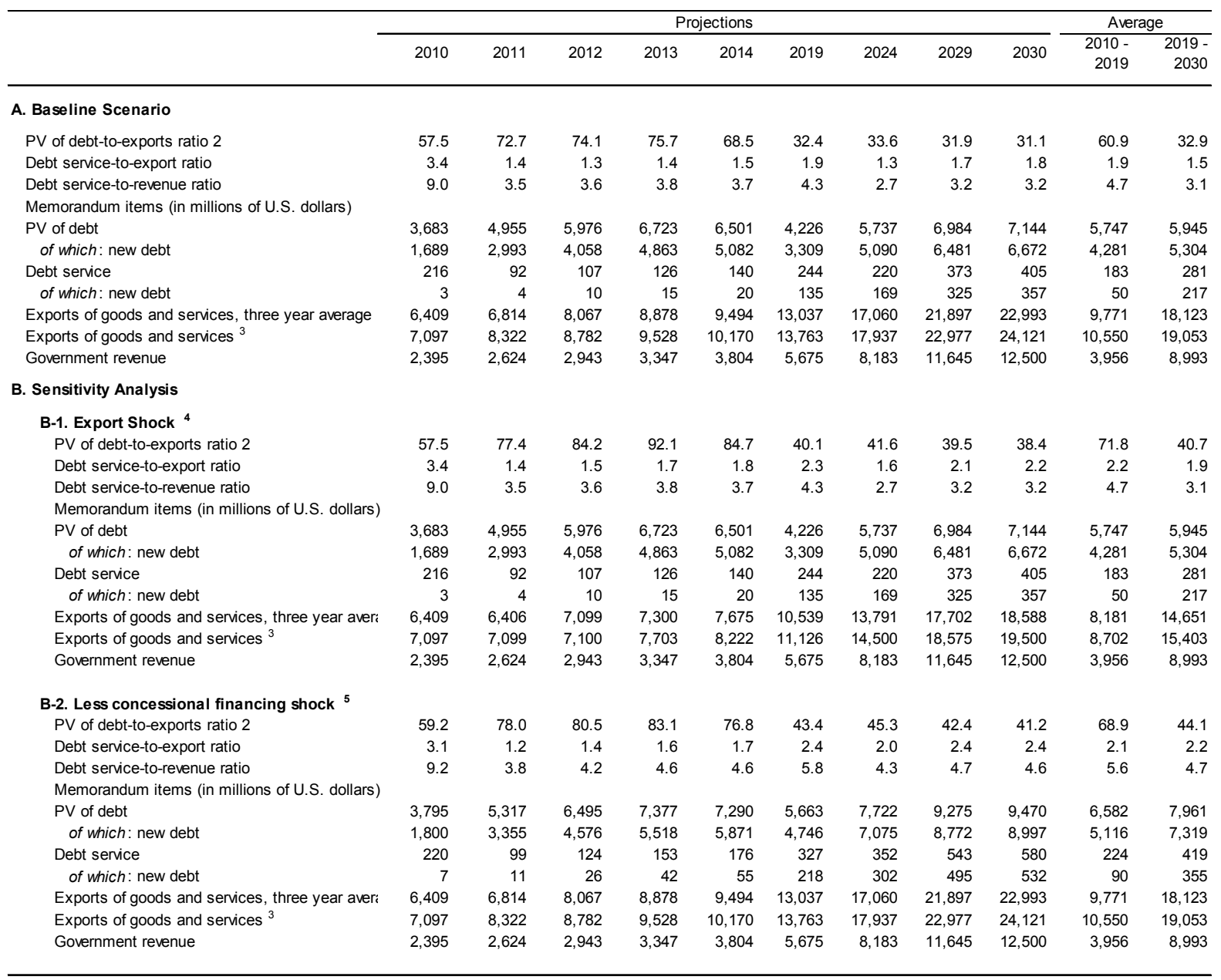

Sources: Congolese authorities; and IMF and World Bank staff estimates and projections.

${ }^{1}$ All debt indicators refer to public and publicly guaranteed debt after full delivery of debt relief (including debt relief beyond the HIPC Initiative and MDRI relief).

${ }^{2}$ Based on a three-year average of exports on the previous year (e.g., export average over 2005-07 for PV of debt-to-exports ratio in 2007).

${ }^{3}$ Exports of goods and services as defined in IMF, Balance of Payments Manual, 5th edition, 1993.

${ }^{4}$ Zero export growth in 2011-12 than baseline scenario.

${ }^{5}$ Less concessional financing terms than baseline scenario. Grant element of new borrowing declines to below 24 percent at 2030. 
Table 13. Democratic Republic of the Congo: Delivery of IMF Assistance under the Enhanced HIPC Initiative and the MDRI, 2003-15 1/

(In millions of SDRs, unless otherwise indicated)

\begin{tabular}{|c|c|c|c|c|c|c|c|c|c|c|c|c|c|c|}
\hline & \multirow{2}{*}{$\begin{array}{r}2003 \\
\text { Aug-Dec }\end{array}$} & \multirow[t]{2}{*}{2004} & \multirow[t]{2}{*}{2005} & \multirow[t]{2}{*}{2006} & \multirow[t]{2}{*}{2007} & \multirow[t]{2}{*}{2008} & \multirow[t]{2}{*}{2009} & \multicolumn{2}{|c|}{2010} & \multirow[t]{2}{*}{2011} & \multirow[t]{2}{*}{2012} & \multirow[t]{2}{*}{2013} & \multirow[t]{2}{*}{2014} & \multirow[t]{2}{*}{2015} \\
\hline & & & & & & & & Jan-Jun & Jul-Dec & & & & & \\
\hline \multicolumn{15}{|l|}{ I. Pre-MDRI Debt relief (under the HIPC Initiative only) 2/ } \\
\hline Projected debt service due on IMF obligations $3 /$ & 1.2 & 2.5 & 2.7 & 2.8 & 44.7 & 89.1 & 99.8 & 52.7 & 52.7 & 110.7 & 69.3 & 24.6 & 27.1 & 42.3 \\
\hline Principal & - & - & - & - & 42.0 & 86.7 & 97.3 & 52.7 & 52.7 & 110.7 & 68.7 & 24.0 & 26.7 & 41.9 \\
\hline Interest 4/ & 1.2 & 2.5 & 2.7 & 2.8 & 2.7 & 2.4 & 2.5 & 0.1 & - & - & 0.6 & 0.5 & 0.5 & 0.4 \\
\hline \multicolumn{15}{|l|}{ HIPC assistance--deposits into member's Umbrella Account } \\
\hline Interim assistance & 1.1 & 1.1 & 1.1 & - & - & - & 45.7 & & & & & & & \\
\hline Completion point disbursement & & & & & & & & 281.6 & & & & & & \\
\hline Completion point assistance $5 /$ & & & & & & & & 231.2 & & & & & & \\
\hline Completion point interest $6 /$ & & & & & & & & 50.4 & & & & & & \\
\hline IMF assistance--drawdown schedule from member's Umbrella Account & 0.6 & 1.1 & 1.14 & 0.59 & 0.01 & 0.0 & 14.6 & 15.5 & 52.7 & 110.7 & 68.7 & 24.0 & 26.7 & 24.4 \\
\hline IMF assistance without interest & 0.6 & 1.1 & 1.13 & 0.56 & - & - & 14.6 & 15.5 & 52.4 & 104.8 & 63.0 & 18.6 & 8.0 & - \\
\hline Estimated interest earnings 6/ & - & 0.005 & 0.01 & 0.03 & 0.01 & 0.0 & 0.0 & 0.0 & 0.3 & 5.9 & 5.7 & 5.4 & 18.7 & 24.4 \\
\hline Debt service due on current IMF obligations after IMF assistance & 0.6 & 1.4 & 1.52 & 2.173 & 44.74 & 89.1 & 85.2 & 37.2 & - & - & 0.6 & 0.5 & 0.5 & 17.8 \\
\hline Delivery schedule of IMF assistance (in percent of the total assistance; on a flow basis) & 0.2 & 0.4 & 0.4 & 0.2 & - & - & 5.2 & 5.5 & 18.7 & 37.4 & 22.5 & 6.6 & 2.8 & - \\
\hline Share of debt service due on IMF obligations covered by HIPC assistance (in percent) & 48.0 & 45.0 & 42.9 & 21.3 & 0.0 & 0.0 & 14.6 & 29.5 & 100.0 & 100.0 & 99.1 & 97.9 & 98.3 & 57.8 \\
\hline \multicolumn{15}{|l|}{ Proportion (in percent) of each repayment falling due during the period to be paid } \\
\hline by HIPC assistance from the principal deposited in Umbrella Account & 50.4 & 50.7 & 50.7 & 20.3 & - & - & 34.8 & 29.5 & 99.5 & 94.7 & 91.7 & 77.4 & 29.9 & - \\
\hline II. Post-MDRI Debt relief (under both MDRI and HIPC Initiatives) & & & & & & & & 297.2 & & & & & & \\
\hline Projected pre MDRI cutoff date debt at completion point $7 /$ & & & & & & & & 248.1 & & & & & & \\
\hline $\begin{array}{l}\text { Delivery of debt relief (on stock basis) 8/: } \\
\text { from the MDRI-I Trust }\end{array}$ & & & & & & & & 248.1 & & & & & & \\
\hline from the HIPC Umbrella Account & & & & & & & & 248.1 & & & & & & \\
\hline Delivery of remaining HIPC assistance for post MDRI cutoff date debt (on stock basis): & & & & & & & & 49.1 & & & & & & \\
\hline III. Debt service due to the IMF after HIPC and MDRI debt relief & 0.6 & 1.4 & 1.5 & 2.2 & 44.7 & 89.1 & 85.2 & 37.2 & - & - & 0.4 & 0.4 & 0.4 & 27.9 \\
\hline Principal & - & - & - & - & 42.0 & 86.7 & 82.7 & 37.1 & - & - & - & - & - & 27.5 \\
\hline Interest & 0.6 & 1.4 & 1.5 & 2.2 & 2.7 & 2.4 & 2.5 & 0.1 & - & - & 0.4 & 0.4 & 0.4 & 0.4 \\
\hline
\end{tabular}

Source: Congolese authorities; IMF staff estimates and projections.

1/ Total IMF assistance under the enhanced HIPC Initiative amounts to SDR 337.5 million (US\$471.5 million) in NPV terms, slightly lower than the amount calculated at the decision point (SDR 337.8 million or US $\$ 472.0$ mllion) owing to debt revisions. Of this amount, SDR 57.2 million (equivalent to about US $\$ 79.9$ million) has been delivered through the concessional element associated with the disbursement of an ECF (formerly PRGF) loan following DRC's arrears clearance to the IMF in June 2002, which is counted toward the IMF's contribution to HIPC assistance. The amount of shortening of the repayment period due to the MDRI stock delivery of debt relief at completion point. To ensure that DRC receives the full share of assistance from the Fund under the HIPC Initiative, Fund staff propos that the amount of the assumed concessional element associated with the ECF loan and taking into account the revisions of debt.

2/ Estimated delivery of HIPC assistance in the absence of MDRI decision.

3/ Data are actual through April 2010. Forthcoming obligations after April 2010 are based on schedules in effect as of end-April 2010. Interest obligations exclude net SDR charges and assessments. 4/ Effective January 7, 2010 interest charges on concessional loans are waived through 12/31/11. The Fund will review interest rates for all concessional facilities in late 2011 and every two years thereafter. After 2011, projected interest charges are based on 0.25 percent per annum for the ECF credit outstanding

at the completion point in June 2010

(b) up to the completion point, amounts committed but not yet disbursed. 7/ Associated with disbursements made prior to December 31, 2004.

8/ Due to an extended interim period and revision of the HIPC assistance, the estimated balance in member's Umbrella Account is sufficient to cover the remaining MDRl-eligible debt. As a result, there will be no resources needed from the MDRI-I Trust. The remaining HIPC resources after covering the MDRI-eligible debt will be used to cover part of debt contracted between end-2004 and completion point.

CInternational Monetary Fund. Not for Redistribution 
Table 14. Democratic Republic of the Congo: Delivery of IDA Assistance Under the Enhanced HIPC Initiative and the MDRI, 2010-44 1/ (In millions of U.S. dollars, unless otherwise indicated)

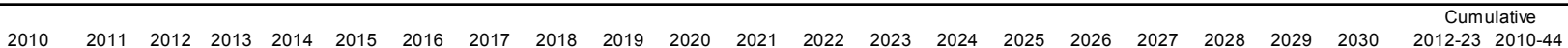

\section{Relief under the Enhanced HIPC Initiative}

Debt service before HIPC assistance 1

of which principal

of which interest

Debt service after HIPC assistance ${ }^{1}$

of which principal

of which interest

Savings on debt senvice to IDA ${ }^{2}$

of which principal

\section{Relief under the MDRI 3 /}

Projected stock of IDA credits outstanding at implementation date ${ }^{4} \quad 2,467.5$

Remaining IDA credits after MDR

844.8

Debt stock reduction on eligible credits ${ }^{35}$

Due to HIPC relief

Due to MDR

Debt service due after HIPC relief and MDR

\section{Memorandum item:}

by HIPC assistance (in percent)

Debt service to IDA covered by HIPC assistance and MDRI (in percent)

IDAdebt service relief under the MDRI (in SDR ${ }^{7}$

$1,622.7$

735.7
887.0

$\begin{array}{cccccccccccccccccccccccc}61.7 & 61.8 & 72.3 & 84.2 & 90.7 & 90.1 & 89.6 & 89.0 & 88.5 & 87.7 & 87.0 & 86.1 & 95.4 & 106.8 & 112.8 & 110.9 & 109.2 & 107.3 & 105.1 & 101.2 & 98.6 & 1,067.5 & 2,813.6 \\ 43.1 & 43.4 & 54.3 & 66.7 & 73.7 & 73.7 & 73.7 & 73.7 & 73.7 & 73.5 & 73.3 & 72.9 & 82.7 & 94.9 & 101.6 & 100.4 & 99.5 & 98.3 & 96.9 & 93.7 & 91.8 & & \\ 18.6 & 18.3 & 18.0 & 17.5 & 17.0 & 16.5 & 15.9 & 15.4 & 14.8 & 14.3 & 13.7 & 13.2 & 12.6 & 12.0 & 11.2 & 10.5 & 9.7 & 9.0 & 8.2 & 7.5 & 6.8 & 180.9 & 316.9 \\ & & & & & & & & & & & & & & & & & & & & \\ 18.5 & 18.5 & 25.4 & 33.9 & 40.7 & 40.4 & 40.2 & 40.0 & 39.7 & 39.5 & 39.2 & 39.0 & 45.6 & 53.8 & 60.5 & 59.9 & 59.4 & 69.4 & 105.1 & 101.2 & 98.6 & 477.5 & 1,946.2 \\ & & & & & & & & & & & & & & & & & & & & & & \\ 8.6 & 8.6 & 15.6 & 24.2 & 31.2 & 31.2 & 31.2 & 31.2 & 31.2 & 31.2 & 31.2 & 31.1 & 38.0 & 46.5 & 53.5 & 53.4 & 53.3 & 62.8 & 96.9 & 93.7 & 91.8 & 373.7 & 1,737.7 \\ 10.0 & 9.9 & 9.8 & 9.7 & 9.5 & 9.3 & 9.0 & 8.8 & 8.6 & 8.3 & 8.1 & 7.9 & 7.6 & 7.3 & 6.9 & 6.5 & 6.1 & 6.7 & 8.2 & 7.5 & 6.8 & 103.8 & 208.5 \\ & & & & & & & & & & & & & & & & & & & & & & \\ 43.2 & 43.2 & 46.9 & 50.3 & 50.0 & 49.7 & 49.4 & 49.1 & 48.7 & 48.2 & 47.8 & 47.1 & 49.8 & 53.0 & 52.4 & 50.9 & 49.8 & 37.9 & 0.0 & 0.0 & 0.0 & 590.0 & 867.4 \\ 34.5 & 34.8 & 38.7 & 42.5 & 42.5 & 42.5 & 42.5 & 42.5 & 42.5 & 42.3 & 42.1 & 41.8 & 44.8 & 48.3 & 48.1 & 47.0 & 46.2 & 35.6 & 0.0 & 0.0 & 0.0 & 512.9 & 759.1 \\ 8.7 & 8.4 & 8.2 & 7.9 & 7.5 & 7.2 & 6.9 & 6.6 & 6.3 & 5.9 & 5.6 & 5.3 & 5.0 & 4.7 & 4.3 & 3.9 & 3.6 & 2.3 & 0.0 & 0.0 & 0.0 & 77.1 & 108.3\end{array}$

$\begin{array}{lllllllllllllllllllllll}14.4 & 6.3 & 11.2 & 17.4 & 23.1 & 23.0 & 22.8 & 22.7 & 22.6 & 22.4 & 22.3 & 22.2 & 26.9 & 33.0 & 38.6 & 38.3 & 38.1 & 37.8 & 37.5 & 37.3 & 37.0 & 308.2 & 981.6\end{array}$

$\begin{array}{lllllllllllllllllllllll}70.0 & 70.0 & 64.8 & 59.8 & 55.1 & 55.1 & 55.1 & 55.1 & 55.1 & 55.0 & 54.9 & 54.7 & 52.2 & 49.6 & 46.4 & 45.9 & 45.6 & 35.3 & - & - & - & 55.3 & 30.8 \\ 76.6 & 89.7 & 84.5 & 79.3 & 74.6 & 74.5 & 74.5 & 74.5 & 74.5 & 74.4 & 74.3 & 74.2 & 71.8 & 69.1 & 65.8 & 65.5 & 65.2 & 64.8 & 64.3 & 63.2 & 62.4 & 71.1 & 65.1\end{array}$

$\begin{array}{lllllllllllllllllllllll}2.7 & 8.0 & 9.3 & 10.8 & 11.5 & 11.5 & 11.4 & 11.3 & 11.3 & 11.2 & 11.1 & 11.0 & 12.3 & 13.7 & 14.4 & 14.2 & 14.0 & 20.7 & 44.3 & 41.9 & 40.4 & 136.4 & 632.7\end{array}$

\section{Source: IDA staff estimate}

1/Principal and interest due to IDA correspond to prorated projections on disbursed and outstanding debt as of end-December 2009, converted to U.S. dollar 2/ Enhanced HIPC assistance from January 2010 to November 2027

$3 /$ Stock of debt and debt service denominated in SDRs are converted into U.S. dollar by applying the end-2009 exchange rate

$5 /$ bit

istanding at the end-September 2010

cancelling arrears to IDA and IBRD loans in arrears as of the decision point date.

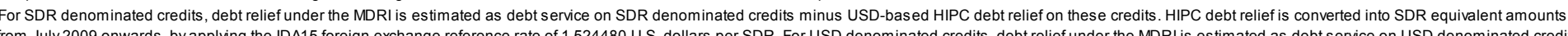

USD-based HIPC debt relief on these credits. The resulting MDRI debt relief amounts are converted into SDR equivalent amounts byapplying the IDA15 foreign exchange reference rate. 
Table 15. Paris Club Creditors' Delivery of Debt Relief Under Bilateral Initiatives Beyond the HIPC Initiative ${ }^{1}$

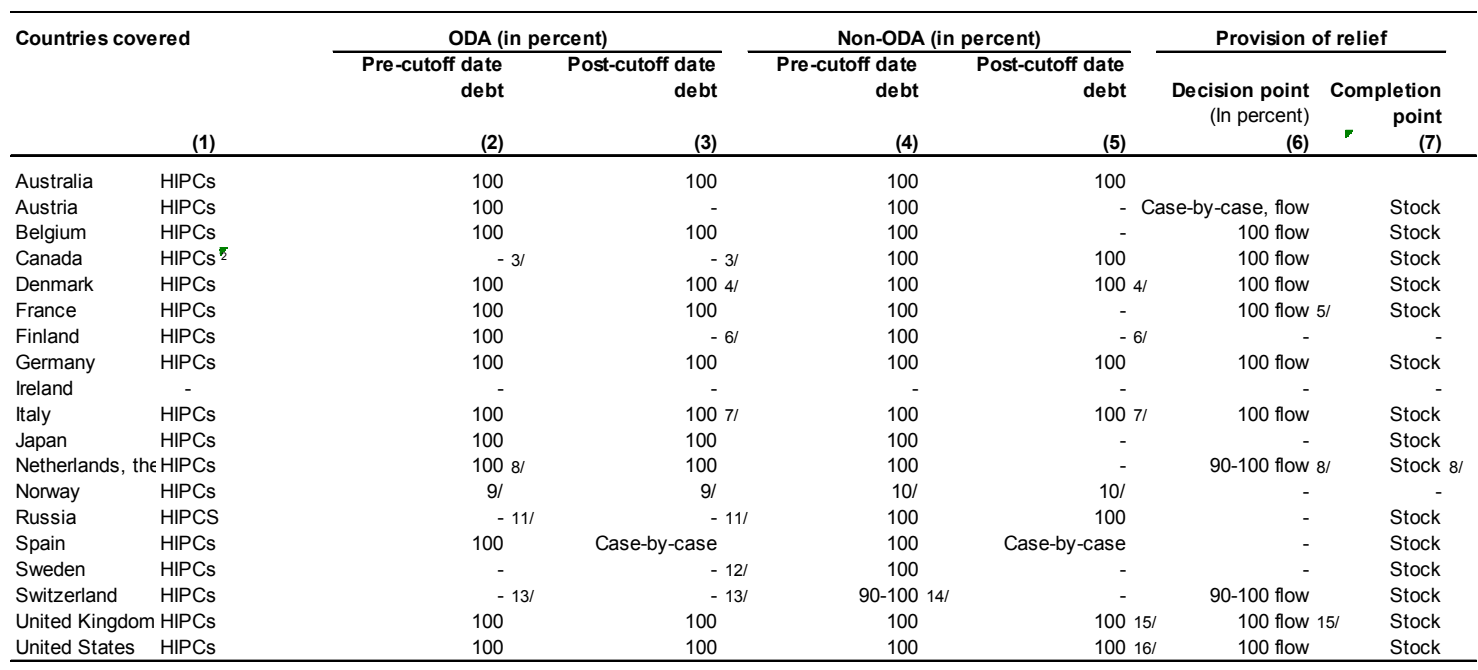

Source: Paris Club Secretariat.

${ }^{1}$ Columns (1) to (7) describe the additional debt relief provided following a specific methodology under bilateral initiatives and need to be read as a whole for each creditor In column (1), "HIPCs" stands for eligible countries effectively qualifying for the HIPC process. A "100 percent" mention in the table indicates that the debt relief provided under the enhanced HIPC Initiative framework will be topped up to 100 percent through a bilateral initiative.

${ }^{2}$ Canada: including Bangladesh. Canada has granted a moratorium of debt service as of January 2001 on all debt disbursed before end-March 1999 for 13 out of 17 HIPCs with debt service due to Canada. Eligible countries are Benin, Bolivia, Cameroon, Dem. Rep. Of Congo, Ethiopia, Ghana, Guyana, Honduras, Madagascar, Rwanda, Senegal, Tanzania, and Zambia. $100 \%$ cancellation will be granted at completion point. As of July 2004, Canada has provided completion point stock of debt cancellation for Benin, Bolivia, Guyana, Senegal and Tanzania.

3100 percent of ODA claims have already been cancelled on HIPCs, with the exception of Myanmar's debt to Canada

${ }^{4}$ Denmark provides 100 percent cancellation of ODA loans and non-ODA credits contracted and disbursed before September $27,1999$.

${ }^{5}$ France: cancellation of 100 percent of debt service on pre-cutoff date commercial claims on the government as they fall due starting at the decision point. Once countries have reached their completion point, debt relief on ODA claims on the government will go to a special account and will be used for specific development projects.

${ }^{6}$ Finland: no post-COD claims

${ }^{7}$ Italy: cancellation of 100 percent of all debts (pre- and post-cutoff date, ODA and non-ODA) incurred before June 20, 1999 (the Cologne Summit). At decision point, cancellation of the related amounts falling due in the interim period. At completion point, cancellation of the stock of remaining debt.

${ }^{8}$ The Netherlands: 100 percent ODA (pre- and post-cutoff date debt will be cancelled at decision point); for non-ODA: in some particular cases (Benin, Bolivia, Burkina Faso, Ethiopia, Ghana, Mali, Mozambique, Nicaragua, Rwanda, Tanzania, Uganda and Zambia), the Netherlands will write off 100 percent of the consolidated amounts on the flow at decision point; all other HIPCs will receive interim relief up to 90 percent reduction of the consolidated amounts. At completion point, all HIPCs will receive 100 per cent cancellation of the remaining stock of the pre-cutoff date debt.

${ }^{9}$ Norway has cancelled all ODA claims.

${ }^{10}$ Due to the current World Bank/IMF methodology for recalculating debt reduction needs at HIPC completion point, Norway has postponed the decisions on whether or not to grant $100 \%$ debt reduction until after the completion point.

${ }^{11}$ Russia has no ODA claims

12 Sweden has no ODA claims.

${ }^{13}$ Switzerland has cancelled all ODA claims.

${ }^{14}$ In some particular cases (Central African Republic, Liberia, Republic of Congo, Sierra Leone, Togo), Switzerland will write off 100 percent of the remaining debt stock at completion point; all other HIPCs will receive debt relief according to Paris Club terms.

${ }^{15}$ United Kingdom: "beyond 100 percent" full write-off of all debts of HIPCs as of their decision points, and reimbursement at the decision point of any debt senvice paid before the decision point.

${ }^{16}$ United States: 100 percent post-cutoff date non-ODA treated on debt assumed prior to June 20, 1999 (the Cologne Summit). 
Table 16. HIPC Initiative: Status of Country Cases Considered Under the Initiative

\begin{tabular}{|c|c|c|c|c|c|c|c|c|c|c|c|}
\hline \multirow{3}{*}{ Country } & \multirow{3}{*}{$\begin{array}{r}\text { Decision } \\
\text { Point }\end{array}$} & \multicolumn{3}{|c|}{$\begin{array}{c}\text { Target } \\
\text { PV of Debt-to- }\end{array}$} & \multirow{2}{*}{\multicolumn{5}{|c|}{$\begin{array}{c}\text { Assistance Levels 1/ } \\
\text { (In millions of U.S. dollars, present value) }\end{array}$}} & \multirow{3}{*}{$\begin{array}{r}\text { Percentage } \\
\text { Reduction } \\
\text { in PV of } \\
\text { Debt 2/ }\end{array}$} & \multirow{3}{*}{$\begin{array}{r}\text { Estimated Total } \\
\text { Nominal Debt } \\
\text { Service Relief } \\
\text { (In millions of } \\
\text { U.S. dollars) }\end{array}$} \\
\hline & & \multirow{2}{*}{$\begin{array}{r}\text { Completion } \\
\text { Point }\end{array}$} & Exports & \multirow{2}{*}{$\begin{array}{l}\text { Gov. } \\
\text { revenue } \\
\text { ent) }\end{array}$} & & & & & & & \\
\hline & & & (in percent) & & Total & commercial & Total & IMF & World Bank & & \\
\hline Completion point reached un & enhanced & amework $(28$ & & & & & & & & & \\
\hline Afghanistan & Jul. 07 & Jan. 10 & 150 & & 582 & 446 & 136 & - & 76 & 51 & 1,280 \\
\hline Benin & Jul. 00 & Mar. 03 & 150 & & 265 & 77 & 189 & 24 & 84 & 31 & 460 \\
\hline Bolivia & & & & & 1,302 & 425 & 876 & 84 & 194 & & 2,060 \\
\hline original framework & Sep. 97 & Sep. 98 & 225 & & 448 & 157 & 291 & 29 & 54 & 14 & 760 \\
\hline enhanced framework & Feb. 00 & Jun. 01 & 150 & & 854 & 268 & 585 & 55 & 140 & 30 & 1,300 \\
\hline Burkina Faso & & & & & 553 & 83 & 469 & 57 & 231 & & 930 \\
\hline original framework & Sep. 97 & Jul. 00 & 205 & & 229 & 32 & 196 & 22 & 91 & 27 & 400 \\
\hline enhanced framework & Jul. 00 & Apr. 02 & 150 & & 195 & 35 & 161 & 22 & 79 & 30 & 300 \\
\hline topping-up & $\ldots$ & Apr. 02 & 150 & & 129 & 16 & 112 & 14 & 61 & 24 & 230 \\
\hline Burundi & Aug. 05 & Jan. 09 & 150 & & 833 & 127 & 706 & 28 & 425 & 92 & 1,366 \\
\hline Cameroon & Oct. 00 & Apr. 06 & 150 & & 1,267 & 879 & 322 & 37 & 176 & 27 & 4,917 \\
\hline Central African Rep. & Sept. 07 & Jun. 09 & 150 & & 578 & 186 & 362 & 27 & 207 & 68 & 804 \\
\hline Congo Rep. of & Mar. 06 & Jan. 10 & & 250 & 1,575 & 1,462 & 113 & 8 & 47 & 31 & 1,738 \\
\hline enhanced framework & Nov. 01 & Apr. 04 & 150 & & 1,275 & 482 & 763 & 34 & 463 & 47 & 1,941 \\
\hline topping-up & & Apr. 04 & 150 & & 707 & 155 & 552 & 26 & 369 & 31 & 1,334 \\
\hline Gambia, The & Dec. 00 & Dec. 07 & 150 & & 67 & 17 & 49 & 2 & 22 & 27 & 112 \\
\hline Ghana & Feb. 02 & Jul. 04 & 144 & 250 & 2,186 & 1,084 & 1,102 & 112 & 781 & 56 & 3,500 \\
\hline Guyana & & & & & 591 & 223 & 367 & 75 & 68 & & 1,354 \\
\hline original framework & Dec. 97 & May 99 & 107 & 280 & 256 & 91 & 165 & 35 & 27 & 24 & 634 \\
\hline enhanced framework & Nov. 00 & Dec. 03 & 150 & 250 & 335 & 132 & 202 & 40 & 41 & 40 & 719 \\
\hline Haiti & Nov. 06 & Jun. 09 & 150 & & 140 & 20 & 120 & 3 & 53 & 15 & 213 \\
\hline Honduras & Jul. 00 & Mar. 05 & 110 & 250 & 556 & 215 & 340 & 30 & 98 & 18 & 1,000 \\
\hline Madagascar & Dec. 00 & Oct. 04 & 150 & & 836 & 474 & 362 & 19 & 252 & 40 & 1,900 \\
\hline Malawi & & & & & 1,057 & 171 & 886 & 45 & 622 & & 1,628 \\
\hline enhanced framework & Dec. 00 & Aug. 06 & 150 & & 646 & 164 & 482 & 30 & 333 & 44 & 1,025 \\
\hline topping-up & $\ldots$ & Aug. 06 & 150 & & 411 & 7 & 404 & 15 & 289 & 35 & 603 \\
\hline Mali & & & & & 539 & 169 & 370 & 59 & 185 & & 895 \\
\hline original framework & Sep. 98 & Sep. 00 & 200 & & 121 & 37 & 84 & 14 & 43 & 9 & 220 \\
\hline enhanced framework & Sep. 00 & Mar. 03 & 150 & & 417 & 132 & 285 & 45 & 143 & 29 & 675 \\
\hline Mauritania & Feb. 00 & Jun. 02 & 137 & 250 & 622 & 261 & 361 & 47 & 100 & 50 & 1,100 \\
\hline Nicaragua & Dec. 00 & Jan. 04 & 150 & & 3,308 & 2,175 & 1,134 & 82 & 191 & 73 & 4,500 \\
\hline Niger & & & & & 663 & 235 & 428 & 42 & 240 & & 1,190 \\
\hline enhanced framework & Dec. 00 & Apr. 04 & 150 & & 521 & 211 & 309 & 28 & 170 & 53 & 944 \\
\hline topping-up & $\ldots$ & Apr. 04 & 150 & & 143 & 23 & 119 & 14 & 70 & 25 & 246 \\
\hline Rwanda & & & & & 696 & 65 & 631 & 63 & 383 & & 1,316 \\
\hline enhanced framework & Dec. 00 & Apr. 05 & 150 & & 452 & 56 & 397 & 44 & 228 & 71 & 839 \\
\hline topping-up & $\ldots$ & Apr. 05 & 150 & & 243 & 9 & 235 & 20 & 154 & 53 & 477 \\
\hline São Tomé and Príncipe & & & & & 124 & 31 & 93 & 1 & 47 & 128 & 263 \\
\hline enhanced framework & Dec. 00 & Mar. 07 & 150 & & 99 & 29 & 70 & - & 24 & 83 & 215 \\
\hline topping-up & $\ldots$ & Mar. 07 & 150 & & 25 & 2 & 23 & 1 & 23 & 45 & 49 \\
\hline Senegal & Jun. 00 & Apr. 04 & 133 & 250 & 488 & 212 & 276 & 45 & 124 & 19 & 850 \\
\hline Sierra Leone & Mar. 02 & Dec. 06 & 150 & & 675 & 335 & 340 & 125 & 123 & 81 & 994 \\
\hline Tanzania & Apr. 00 & Nov. 01 & 150 & & 2,026 & 1,006 & 1,020 & 120 & 695 & 54 & 3,000 \\
\hline Uganda & & & & & 1,003 & 183 & 820 & 160 & 517 & & 1,950 \\
\hline original framework & Apr. 97 & Apr. 98 & 202 & & 347 & 73 & 274 & 69 & 160 & 20 & 650 \\
\hline enhanced framework & Feb. 00 & May 00 & 150 & & 656 & 110 & 546 & 91 & 357 & 37 & 1,300 \\
\hline Zambia & Dec. 00 & Apr. 05 & 150 & & 2,499 & 1,168 & 1,331 & 602 & 493 & 63 & 3,900 \\
\hline Decision point reached unde & lanced fra & ework (7) & & & & & & & & & \\
\hline Chad & May. 01 & Floating & 150 & & 170 & 35 & 134 & 18 & 68 & 30 & 260 \\
\hline Cote d'Ivoire & Mar. 09 & Floating & & 250 & 3,005 & 2,311 & 694 & 38 & 402 & 24 & 3,129 \\
\hline Congo, Democratic Rep. of & Jul. 03 & Floating & 150 & & 6,311 & 3,837 & 2,474 & 472 & 831 & 80 & 10,389 \\
\hline Guinea & Dec. 00 & Floating & 150 & & 545 & 215 & 328 & 31 & 152 & 32 & 800 \\
\hline Guinea-Bissau & Dec. 00 & Floating & 150 & & 416 & 212 & 204 & 12 & 93 & 85 & 790 \\
\hline Liberia & Mar. 08 & Floating & 150 & & 2,846 & 1,420 & 1,426 & 732 & 375 & 91 & 4,008 \\
\hline Togo & Nov. 08 & Floating & & 250 & 270 & 120 & 150 & 0.3 & 98 & 19 & 360 \\
\hline Total assistance provided/cor & & & & & 42,597 & 21,786 & 20,682 & $3,406 \quad 3 /$ & 9,728 & & 70,529 \\
\hline
\end{tabular}

Sources: IMF andWorld Bank Board decisions, completion point documents, decision point documents, preliminary HIPC documents, and staff calculations

1/ Assistance levels are at countries' respective decision or completion points, as applicable.

2/ In percent of the present value of debt at the decision or completion point (as applicable), after the full use of traditional debt-relief mechanisms.

3/ Equivalent to SDR 2181.98 million at an SDR/USD exchange rate of 0.640563, as of January 27, 2010. 


\section{APPENDIX I}

\section{The Democratic Republic OF THE CONGO}

\section{Debt Management}

1. DGDP is a department in the Ministry of Finance, responsible for the analysis and management of the public debt portfolio. At the time of its creation in 1976, DGDP was an autonomous public agency; however, recent evolutions in the legal framework as of 2009 have integrated DGDP into the Ministry of Finance.

\section{Legal Framework}

2. While allowing for the centralization of responsibility for the public debt portfolio at DGDP, the integration of DGDP into the Ministry of Finance has also required DGDP to integrate itself into new procedural arrangements that can lead to lengthy delays in information sharing and decision making. It has also necessitated a concerted effort to sensitize government agencies, public enterprises, provincial governments and the general public about DGDP's role. Informational road shows explaining the legal mandate as well as the action plan have been undertaken regularly since November 2009, with the help of external funding, and the government is currently preparing a progress report on these activities.

\section{Staff Capacity}

3. Six staff members were trained in the use of DMFAS at the time of its installation, but there has not been a comprehensive training since that time and debt managers are still unfamiliar with some of the system's more advanced functions. Human error remains a common issue in data entry and retrieval, as instructions are often transposed by hand and back-office personnel are generally unfamiliar with financial conventions. With additional training for personnel, such operational risks could be minimized. DGDP has elaborated a manual of procedures that would govern the process of entering and retrieving information; however, they are still awaiting approval of this document and are not closely following it currently. Difficulties in staff capacity can also be traced to the departure of key trained personnel.

\section{Debt Strategy and Policy Coordination}

4. DGDP currently does not have an approved debt management strategy; though in principle it follows commonly accepted practice such as the maximization of concessional debt with at least a 35 percent grant element. The elaboration of a comprehensive debt management strategy is included in the matrix of reforms and will require the approval of the Minister of Finance. DGDP needs to elaborate an action plan to improve coordination with monetary and fiscal authorities. At present, the ability of DGDP 
to supply the Ministry of Budget with reliable and timely debt projections is limited by its ability to receive this data from other agencies and synthesize it in the appropriate timeframe.

\section{Debt Records and Reporting}

5. Frictions in the expenditure chain are such that payment information is slow in reaching the $\mathrm{BCC}$ and can result in late payments and charges even if the order of payment is given over a month in advance of the payment date. Since DGDP is only notified that a payment has been made after the fact, this means that payment records are updated with some delay. In an effort to ensure accuracy, DGDP does not officially record payments until creditors confirm they have been received, which leads to additional delays in data recording as some creditors do not respond in a timely manner. This is a contributing factor to continuing inconsistencies in the debt database. While Ministries of Finance and Budget, as well as the BCC and Treasury meet once a month to reconcile payment data, a new web-based version of DMFAS would connect DGDP electronically to these agencies and shorten the time necessary for payments to be effected. DGDP has laid the groundwork for the upgrade with the assistance of UNCTAD and is awaiting sufficient donor financing.

6. The problem of accurate recording is even more severe in the case of disbursements, and is the principal reason why a majority of the disbursement data needed to be updated during the debt reconciliation mission. Disbursements are made directly to the end user and do not pass through DGDP in any form. While the recipient entities are expected to report disbursements to DGDP they often do not. There currently is an effort underway to centralize this data through a platform at the Ministry of Planning; however, it is not fully functional.

7. Three annual debt statistical bulletins were published at the end of 2008, 2009 and March 2010. The last, which includes debt data assessed at December 31, 2009, is consistent with international standards and with the IMF and the IDA current practice, in terms of scope and information content. They are available on the government's website. 


\section{APPENDIX II}

\section{The Democratic Republic Of THE Congo}

\section{Debt SuStainability ANALYSIS USING THE LOW-INCOME COUNTRY FrameWORK}

1. As in the case of the most recent low-income country debt sustainability analysis (LIC DSA) conducted in December 2009, the DRC would continue to face a high risk of debt distress after receiving debt relief from all creditors under the enhanced HIPC Initiative and MDRI. The PV of external debt-to-GDP indicator breaches the policy-dependent threshold in the baseline scenario and the external debt outlook is vulnerable to adverse shocks. However, the breach is relatively small and short-lived and is mainly due to the inclusion of debt related to a public guarantee on external borrowing to finance public infrastructure projects under the SCCA. Without the guarantee, all external debt indicators would remain well below their respective thresholds and the risks to debt sustainability therefore appear to be manageable.

\section{BACKGROUND}

\section{This LIC DSA for the DRC assesses its public and external debt dynamics using} the forward-looking debt sustainability framework (DSF) for low-income countries. The LIC DSA uses the reconciled debt database prepared for the completion point HIPC DSA, and incorporates the impact of HIPC, additional bilateral assistance beyond HIPC, and MDRI relief in the baseline scenario. The LIC DSA and the HIPC DSA share the same macroeconomic assumptions in the baseline and alternative scenarios but differ in four key areas: (i) the discount rate for the LIC DSA is fixed at 4 percent, compared to the currencyspecific six-month averages of commercial interest reference rates for the HIPC DSA; (ii) the LIC DSA uses exchange rate projections from the World Economic Outlook instead of actual exchange rates at end-2009 used for the HIPC DSA; (iii) exports used for the debt burden indicators in the LIC DSA are the latest projections rather than three-year backward-looking averages and (iv) the baseline in the LIC DSA assumes that IDA assistance is delivered in the form of concessional loans rather than mainly grants as in the HIPC DSA.

In the LIC DSA framework the PV of the DRC's public and publicly guaranteed (PPG) external debt is US\$2.4 billion (23.8 percent of GDP) at end 2009, assuming full delivery of HIPC and MDRI assistance. Around three-fifths of this debt would be owed to multilateral creditors, with the balance owed to official bilateral and commercial creditors almost equally (18 and 20 percent respectively). The bulk of external debt owed to commercial creditors is a public guarantee on loans for public infrastructure projects provided under the terms of the SCCA. ${ }^{1}$

\footnotetext{
${ }^{1}$ Details of this agreement are outlined in IMF Country Report No. 10/88 (Box 3) and IDA/SecM2010-0285 (Box 2).
} 


\section{The DRC has made good-faith efforts to normalize relations with all external} creditors. The DRC has not accumulated arrears with multilateral creditors since the commencement of the current ECF arrangement in July 2009. ${ }^{2}$ In February 2010, Paris Club agreed to reschedule the DRC's debt under exceptional terms, which reduced debt service (including arrears) due by some 97 percent over the period July 2009 to June 2012 (the period covered by the current ECF arrangement). The DRC authorities then requested comparable terms from its other creditors. They have maintained contact with their creditors to keep them informed about ongoing developments with the Paris Club and the HIPC completion point process more generally, and have engaged in negotiations to make interim debt service payments taking into account their limited fiscal capacity.

\section{External Debt Sustainability Analysis}

4. The baseline scenario in this DSA assumes a strong recovery in economic activity over the medium term, supported by large investments in mining and public infrastructure projects. In particular, it assumes that the security situation stabilizes and that the government adopts prudent macroeconomic policies and makes significant progress on key structural reforms, including strengthening tax collection, improving budget preparation and execution, and reforming the civil service. The near-term outlook is dominated by a rebound in world commodity prices (copper in particular) and external demand associated with the global economic recovery, followed by a strong recovery over the medium term fueled by a US $\$ 3.2$ billion investments in a mining project along with US $\$ 3$ billion in investments in public infrastructure projects envisaged under the SCCA. Real GDP growth is projected to increase from 2.8 percent in 2009 to an average rate of 6.8 percent in $2010-15$ and then gradually decline to 4.4 percent in the long run.

\section{Government revenues (excluding grants) are projected to rebound from}

17 percent of GDP in 2009 to 20 percent in 2010, and then increase gradually to just under 24 percent over the long term. Meanwhile grants drop sharply from 11.7 percent of GDP in 2009 to 6.6 percent in 2010 and then decline gradually to under 4 percent in the long run.

6. The current account deficit widens dramatically from 10 percent of GDP in 2009 to over 20 percent in 2010-11, mainly due to a large increase in imported factors used in the mining and public infrastructure projects. The deficit narrows thereafter as mining exports expand and investment-related imports diminish over time, gradually declining below 4 percent of GDP by the end of the 20-year projection horizon. Much of the widening in the current account deficit in 2010-11 is covered by net FDI, which increases from 5.7 percent of GDP in 2000 to 8.6 percent in 2011 and then quickly falls back to 5.6 percent in 2013. The surge in FDI inflows reflects foreign investment in a series of mining projects planned over the next few years (notably those financed under the SCCA).

\footnotetext{
${ }^{2}$ See discussion of non-accumulation of external arrears in accompanying IMF Staff Report.
} 


\section{External financing in the short term is dominated by loans disbursed to fund} public infrastructure projects under the SCCA, which account for over one half of gross borrowing needs over the period 2010-14. The average grant element of new borrowing rises steadily from 20 percent in $2010-11^{3}$ to just over 48 percent in $2015-16$ and then declines gradually to under 45 percent in the long run. This profile reflects three factors: (i) public infrastructure loans disbursed under the SCCA in 2010-14 have a much lower grant element ( 2 percent) than other sources of external financing; (ii) the IMF purchases under the current ECF arrangement have a lower grant element than funds provided by other multilateral creditors; and (iii) the country makes a gradual transition away depending exclusively on external financing from multilateral creditors to financing from official bilateral creditors as the economy develops over time.

\section{The baseline scenario assumes that the HIPC completion point is reached in}

June 2010. Under the assumption that all creditors provide debt relief under the HIPC/MDRI Initiatives, the PV of PPG external debt at end-2009 would be US\$2.4 billion, an amount equal to 24.1 percent of GDP, 52.6 percent of exports and 141.1 percent of government revenue (excluding grants). Each of the three external debt indicators is well below the policy-dependent threshold levels of 30 percent, 100 percent and 200 percent, respectively. ${ }^{4}$ By contrast, in the most recent LIC DSA, ${ }^{5}$ the PV of PPG external debt at end2009 was US\$11.5 billion in the baseline scenario, which assumed that creditors would provide interim HIPC relief but did not assume that the completion point would be reached. In that scenario, all three external debt indicators were well above the thresholds in 2009 (104 percent of GDP, 256 percent of exports and 572 percent of government revenue), and for most of the 20-year projection period, indicating that the DRC was in debt distress.

\section{Under the baseline scenario, one external debt burden indicator breaches}

the policy-dependent threshold (see Figure 1). The PV of external debt burden is projected to increase sharply over the medium term, with the PV of external debt reaching US $\$ 6.7$ billion in 2016, almost three times the level in 2009. The external debt-to-GDP indicator breaches the 30 percent threshold over a six-year period (2011-16), averaging 36 percent in $2012-15$.

\footnotetext{
${ }^{3}$ The average grant element on new borrowing is well below the 35 percent grant element required to qualify as concessional under the current ECF arrangement. This is because the concessionality calculation used to assess the average grant element under the terms of an IMF program uses a much higher discount rate than that used in the LIC DSA. For example, the public infrastructure financed under the terms of the SCCA have a grant element of 38 percent based on the appropriate discount factor of 6.4 percent for the U.S. dollar, compared to a grant element of only 2 percent based on a discount factor of 4 percent used in the LIC DSA.

${ }^{4}$ With an average CPIA rating of 2.80 in 2006-08, the DRC is classified as having a weak policy framework.

${ }^{5}$ Done in November 2009 IMF Country Report No. 10/88, and IDA/SecM2010-0285.
} 


\section{The significant increase in the external debt indicators over the medium term is} mainly due to a public guarantee on external borrowing to finance public infrastructure projects under the SCCA. Under an alternative (counterfactual) scenario where the DRC government did not provide the public guarantee, all external debt indicators would be well below their respective thresholds (see Figure 2). The public infrastructure loans are repaid from operating profits on a mining project also financed under the SCCA. ${ }^{6}$ The inclusion of the public guarantee in the baseline scenario therefore substantially overstates the risk of debt distress.

\section{The baseline projections are subject to significant downside risks. Given the} DRC's high dependence on mining exports, the external account and overall economic outlook remains highly vulnerable to adverse terms-of-trade shocks. Moreover, poor governance, unresolved security issues, weak implementation capacity, and lower-thanenvisaged donor support could also worsen the external debt outlook significantly.

\section{The external debt outlook is vulnerable to large adverse shocks. All three debt} burden indicators exceed the thresholds under the most extreme stress tests. The debt profile is most vulnerable to two shocks in particular: (1) less concessional terms of external financing; and (2) a sharp drop in exports in 2010-11 (see Figure 1). With regard to the latter, the external debt-to-exports indicator breaches the threshold by a wide margin and remains above the threshold throughout most of the 20-year projection period. This is because of the large magnitude of the export shock. Under this stress test, exports decline by some 38 percent in 2011-12, compared to a 19 percent increase in the baseline scenario. Under a less extreme stress test where export growth is zero in 2011-12, the external debtto-export indicator would not breach the threshold. Under the historical scenario, the external debt burden indicators decline rapidly. This reflects the fact that the country did not have access to external financing during the conflict period, which restricted the noninterest current account deficit.

\section{Public Debt Sustainability Analysis}

\section{The DRC's domestic debt is relatively low and as a result, the above} sustainability analysis for external debt broadly applies to total public debt, albeit with slightly higher debt burden indicators (see Figure 3). Although information on domestic debt is poor, the authorities recently provided updated estimates on claims of about US $\$ 1.2$ billion at end-2009 (11 percent of GDP). These claims are mainly from suppliers, public enterprises and public sector employees dating back to the period of conflict in the 1990s. The authorities are in the process of developing a strategy to deal with these claims.

\footnotetext{
${ }^{6}$ Calculations based on a model of income generated by the mining project developed by the DRC authorities predict that the net operating profits from the mining project would fully repay the public infrastructure loans by 2018, 16 years before the public guarantee would be invoked. Moreover, net operating income would have to decline by 65 percent of the amount projected in the baseline scenario in order for the public guarantee to be invoked.
} 


\section{CONCLUSION}

14. The LIC DSA indicates that the DRC faces a high risk of debt distress after receiving debt relief from all creditors under the enhanced HIPC/MDRI Initiatives.

The external debt-to-GDP indicator breaches the policy-dependent threshold in the baseline scenario. The breach is relatively small and short-lived and is mainly due to a public guarantee on public infrastructure loans under the SCCA, but projections are subject to significant downside risks which tip the balance toward a high risk rating. 
Figure 1. Democratic Republic of the Congo: Indicators of Public and Publicly

Guaranteed External Debt under Alternatives Scenarios, 2010-30 1/
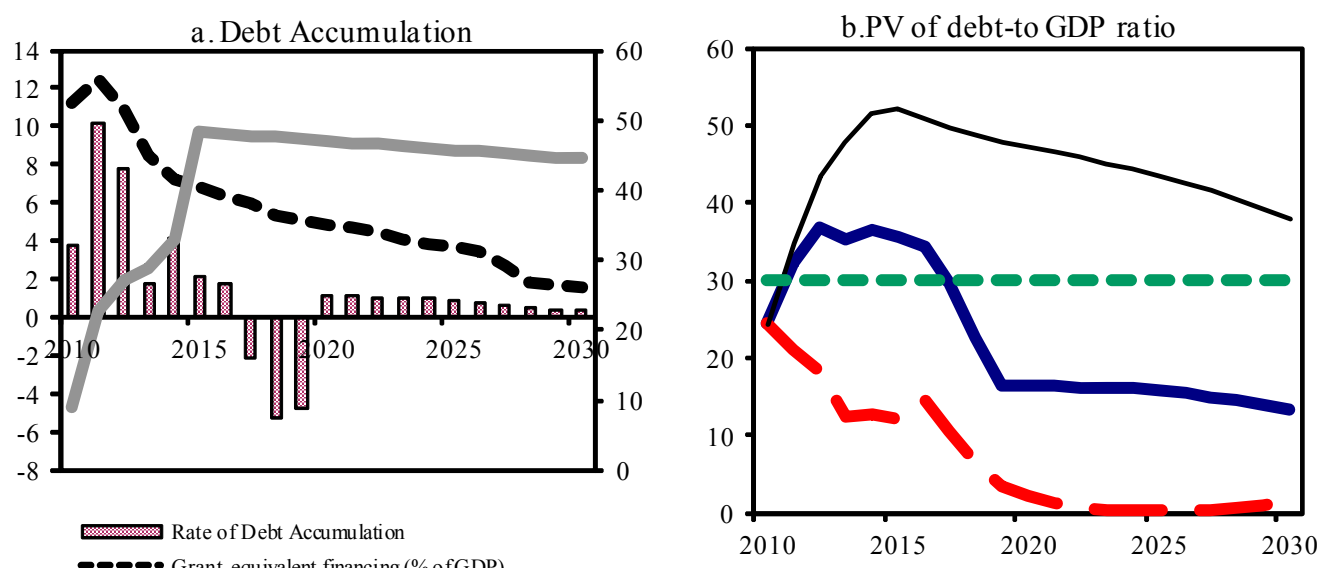

- - Grant-equivalent financing (\% ofGDP)

Grant element of new borrowing (\% right scale)
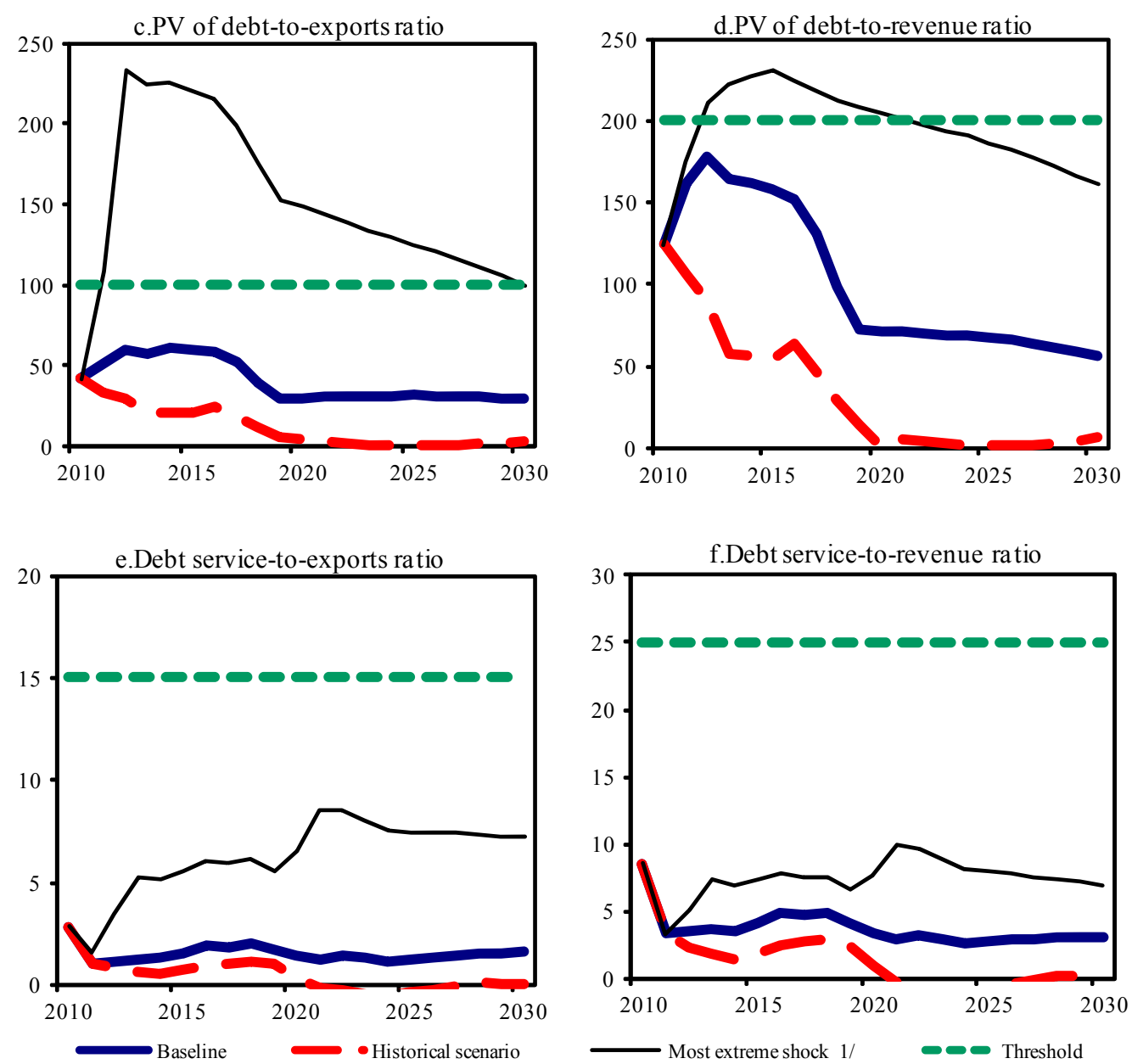

Sources: Country authorities; and IMF staff estimates and projections.

$1 /$ The most extreme stress test is the test that yields the highest ratio in 2020. In figure b. it corresponds to a Terms shock; in c. to a Exports shock; in d. to a Terms shock; in e. to a Exports shock and in figure f. to a Terms shock 
Figure 2. Democratic Republic of the Congo: Indicators of Public and Publicly Guaranteed External Debt with and without Public Guarantee on Public Infrastructure Projects, 2010-30

a.PV of debt-to-GDP ratio

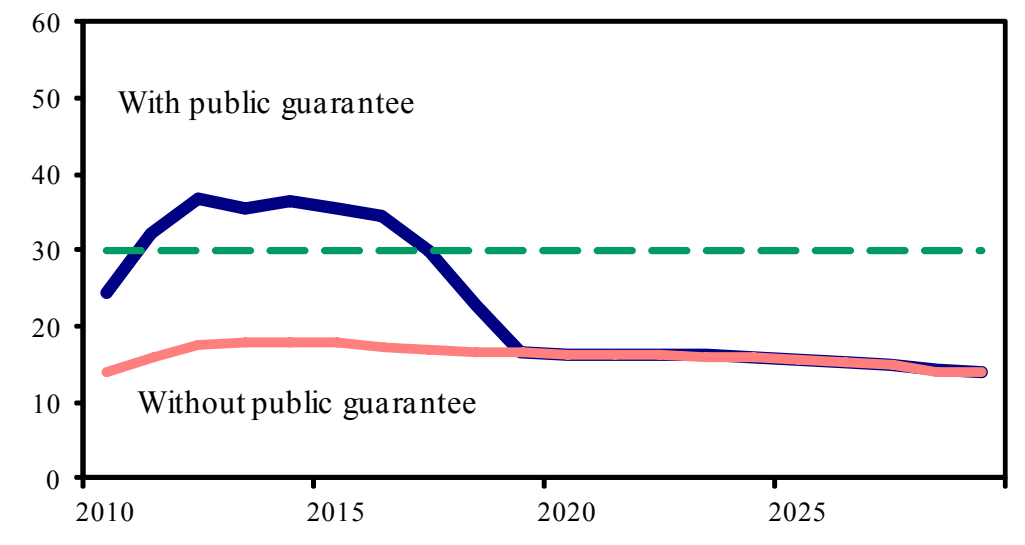

b.PV of debt-to-exports

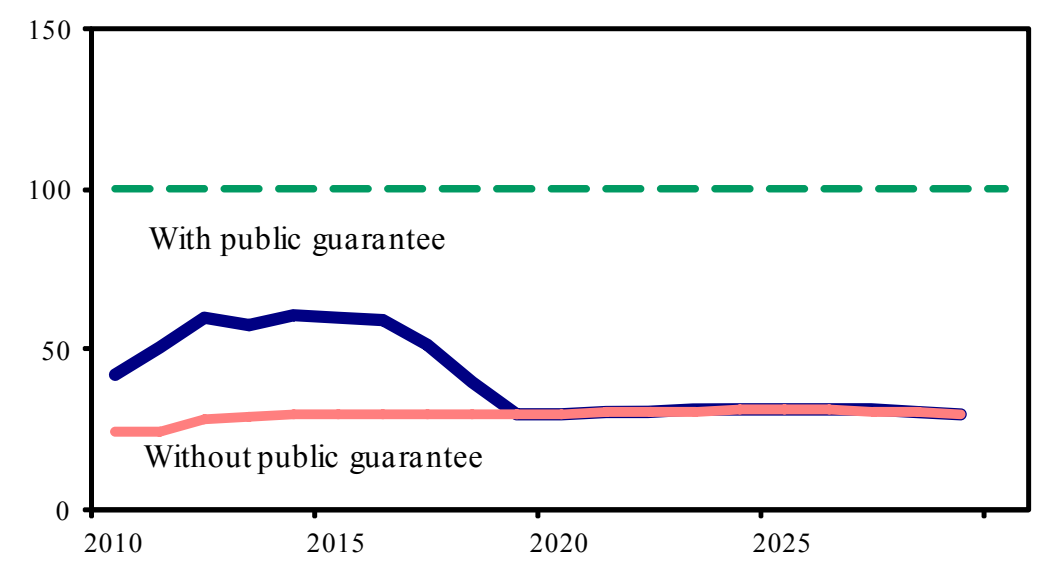

c. PV of debt-to-revenue ratio

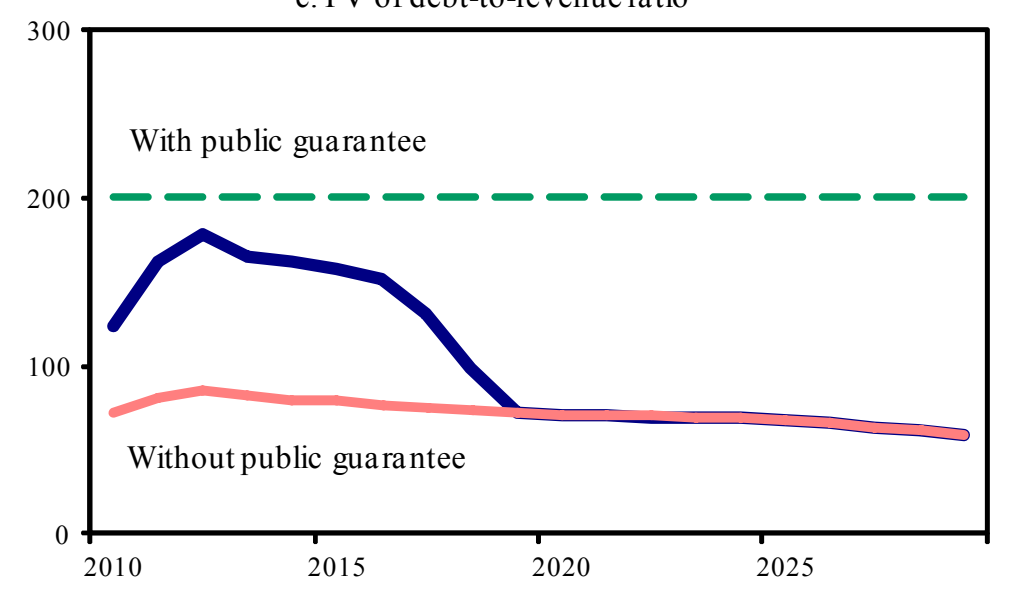

Sources: Country authorities; and IMF staff estimates and projections. 
Figure 3.Democratic Republic of the Congo: Indicators of Public Debt Under Alternative Scenarios, 2010-30 1/
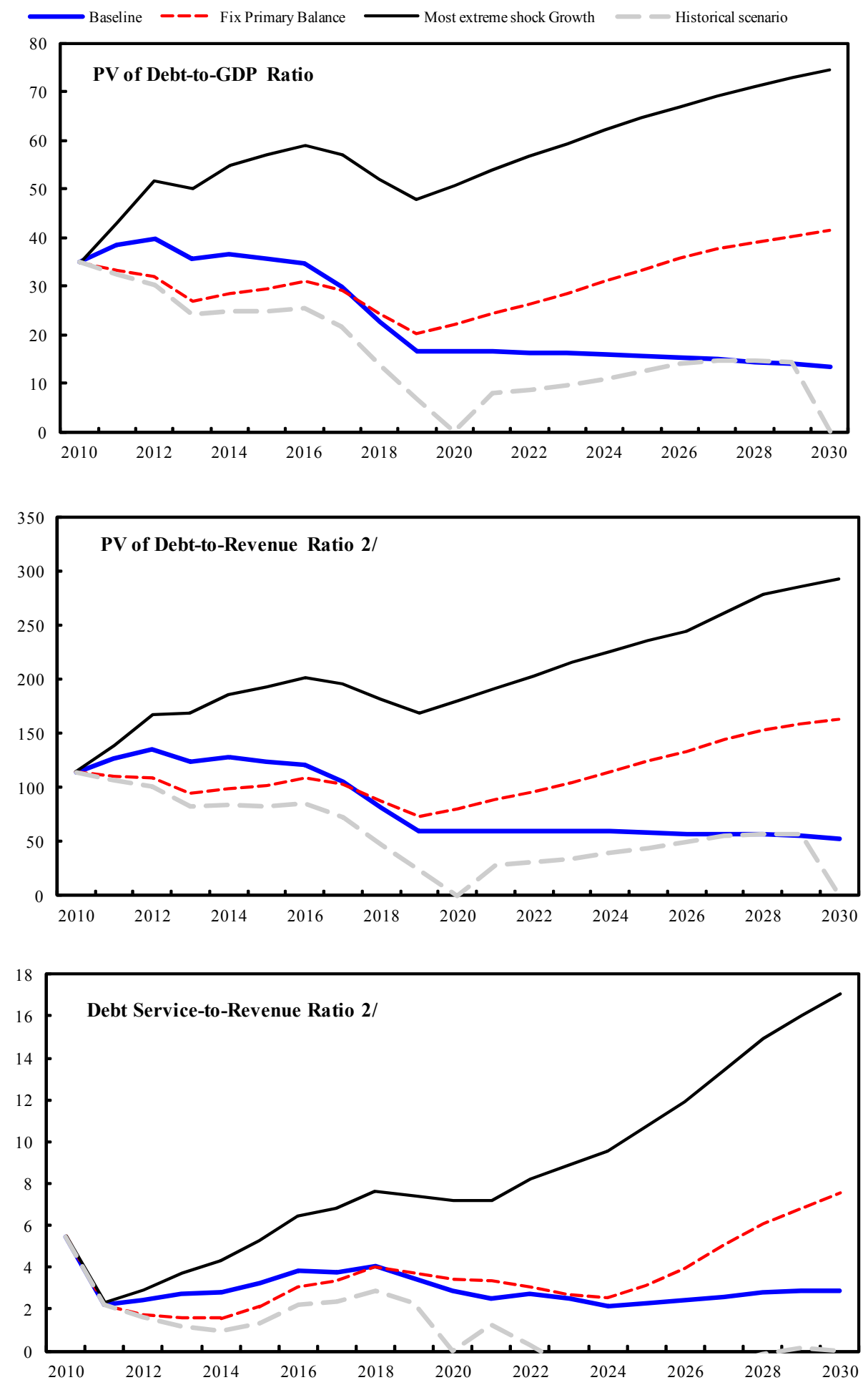

Sources: Country authorities; and IMF staff estimates and projections.

1/ The most extreme stress test is the test that yields the highest ratio in 2020.

2/ Revenues are defined inclusive of grants. 
Table 1: Democratic Republic of the Congo: External Debt Sustainability Framework, Baseline Scenario, 2007-30

(In percent of GDP, unless otherwise indicated)

\begin{tabular}{|c|c|c|c|c|c|c|c|c|c|c|c|c|c|c|c|}
\hline & \multicolumn{3}{|c|}{ Actual } & \multirow{2}{*}{$\begin{array}{l}\text { Historical } \\
\text { Average }\end{array}$} & \multirow{2}{*}{$\begin{array}{l}\text { Standard } \\
\text { Deviation }\end{array}$} & \multicolumn{6}{|c|}{ Projections } & \multirow[b]{2}{*}{$\begin{array}{c}2010-2015 \\
\text { Average }\end{array}$} & \multirow[b]{2}{*}{2020} & \multirow{2}{*}{\multicolumn{2}{|c|}{$\begin{array}{lc}2016-2030 \\
2030 \quad \text { Average } \\
\end{array}$}} \\
\hline & 2007 & 2008 & 2009 & & & 2010 & 2011 & & & 2014 & 2015 & & & & \\
\hline External debt (nominal) 1/ & 125.7 & 132.5 & 21.1 & & & 25.5 & 35.0 & 41.1 & 43.6 & 45.2 & 44.7 & & 26.5 & 20.6 & \\
\hline $\begin{array}{l}\text { o/w public and public } \\
\text { Change in external debt }\end{array}$ & & 132.5 & 21.1 & & & 25.5 & 35.0 & & & 45.2 & & & & & \\
\hline $\begin{array}{l}\text { Change in external debt } \\
\text { Identified net debt-creating flows }\end{array}$ & -22.9 & & -111.3 & & & 4.4 & 9.5 & 6.1 & 2.5 & 1.6 & -0.5 & & -0.2 & -1.0 & \\
\hline $\begin{array}{l}\text { Identified net debt-creating flows } \\
\text { Non-interest current account deficit }\end{array}$ & -20.2 & -16.0 & 12.6 & & 46. & 13.4 & 11.3 & 8.4 & 5.4 & 0.2 & -1.0 & & 1.3 & -1.4 & \\
\hline Deficit in balance of goods and services & $\begin{array}{r}-2.5 \\
3.4\end{array}$ & 15.1 & $\begin{array}{l}15.1 \\
15.9\end{array}$ & 4.1 & 4.0 & 19.7 & 20.0 & 15.8 & 15.5 & $\begin{array}{l}7.3 \\
9.5\end{array}$ & $\begin{array}{l}6.3 \\
8.4\end{array}$ & & 9.0 & $\begin{array}{l}3.8 \\
4.0\end{array}$ & 4. \\
\hline Exports & 65.2 & 61.3 & 45.8 & & & 58.2 & 63.1 & 61.6 & 61.3 & 60.4 & 59.5 & & 54.8 & 45.5 & \\
\hline Imports & 68.6 & 76.4 & 61.7 & & & 77.9 & 83.0 & 77.4 & 76.8 & 69.9 & 67.8 & & 63.9 & 49.5 & \\
\hline nt transfers (negative $=$ inflow) & -8.6 & $\begin{array}{l}-10.6 \\
-8 .\end{array}$ & -12.8 & -7.4 & 2.8 & -7.3 & -6.6 & -6.3 & -6.1 & $\begin{array}{c}-6.0 \\
53\end{array}$ & -5.9 & & -5.4 & -4.3 & -5.1 \\
\hline $\begin{array}{l}\text { o/w official } \\
\text { Other current ac }\end{array}$ & -7.4 & $\begin{array}{r}-8.8 \\
8.2\end{array}$ & $\begin{array}{r}-11.7 \\
3.9\end{array}$ & & & $\begin{array}{l}-6.6 \\
8.0\end{array}$ & $\begin{array}{l}-5.9 \\
8.0\end{array}$ & $\begin{array}{l}-5.5 \\
8.2\end{array}$ & $\begin{array}{c}-5.4 \\
3.9\end{array}$ & $\begin{array}{l}-5.3 \\
3.8\end{array}$ & $\begin{array}{l}-5.2 \\
3.8\end{array}$ & & $\begin{array}{r}-4.7 \\
36\end{array}$ & $\begin{array}{l}-3.6 \\
42\end{array}$ & \\
\hline $\begin{array}{l}\text { Ohther current a account flows (nega } \\
\text { Net FDI (negative }=\text { inflow) }\end{array}$ & $\begin{array}{c}2.7 \\
-3.7\end{array}$ & $\begin{array}{r}8.2 \\
-14.8\end{array}$ & $\begin{array}{r}3.9 \\
-57\end{array}$ & & & $\begin{array}{r}8.0 \\
-6.6\end{array}$ & $\begin{array}{r}8.0 \\
-8.6\end{array}$ & $\begin{array}{c}8.22 \\
-7.4\end{array}$ & $\begin{array}{r}3.9 \\
-56\end{array}$ & $\begin{aligned} 3.8 \\
-5.4\end{aligned}$ & $\begin{aligned} 3.8 \\
-5.3\end{aligned}$ & & $\begin{array}{r}3.6 \\
-5.0\end{array}$ & $\begin{array}{r}4.2 \\
-46\end{array}$ & \\
\hline Endogenous debt dynamics $2 /$ & -13.9 & $\begin{array}{l}-13.9 \\
-13.9\end{array}$ & $\begin{array}{c}-5.7 \\
11.3\end{array}$ & -5.0 & 4.0 & $\begin{array}{l}-0.0 \\
-0.4\end{array}$ & $\begin{array}{l}-8.6 \\
-1.5\end{array}$ & $\begin{array}{l}-7.4 \\
-2.0\end{array}$ & $\begin{array}{l}-5.6 \\
-2.3\end{array}$ & $\begin{array}{ll}-5.8 \\
-1.8\end{array}$ & $\begin{array}{l}-5.3 \\
-2.0\end{array}$ & & $\begin{array}{l}-5.0 \\
-0.9\end{array}$ & $\begin{array}{l}-4.6 \\
-0.7\end{array}$ & ${ }_{-4.8}$ \\
\hline Contribution from nominal interest rate & 3.9 & 3.1 & 3.6 & & & 0.6 & 0.2 & 0.2 & 0.8 & 0.9 & 0.9 & & 0.2 & 0.2 & \\
\hline Contribution from real GDP growth & -8.2 & -6.7 & -4.0 & & & -1.0 & -1.6 & -2.2 & -3.0 & -2.7 & -2.9 & & -1.2 & -0.9 & \\
\hline Contribution from price and excha & -9.7 & -10.3 & 11.7 & & & & & & & & & & & & \\
\hline $\begin{array}{l}\text { Residual (3-4) 3/ } \\
\text { o/w exceptional financing }\end{array}$ & $\begin{array}{r}-2.7 \\
0.0\end{array}$ & $\begin{array}{r}22.8 \\
0.0\end{array}$ & $\begin{array}{r}-124.0 \\
0.0\end{array}$ & & & $\begin{array}{r}-9.0 \\
0.0\end{array}$ & $\begin{array}{r}-1.8 \\
0.0\end{array}$ & $\begin{array}{r}-2.3 \\
0.0\end{array}$ & $\begin{array}{r}-2.9 \\
0.0\end{array}$ & $\begin{array}{l}1.4 \\
0.0\end{array}$ & $\begin{array}{c}0.5 \\
0.0\end{array}$ & & $\begin{array}{r}-1.5 \\
0.0\end{array}$ & $\begin{array}{c}\mathbf{0 . 4} \\
0.0\end{array}$ & \\
\hline PV of external debt $4 /$ & $\cdots$ & ... & 24.1 & & & 24.4 & 32.2 & & 35.4 & 36.6 & 35.6 & & 16.4 & 13.3 & \\
\hline 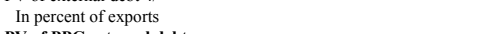 & $\ldots$ & $\ldots$ & 52.6 & & & 42.0 & 51.0 & 59.7 & 57.8 & 60.6 & 59.9 & & 29.9 & 29.1 & \\
\hline PV of PPG external debt & ... & $\ldots$ & 24.1 & & & 24.4 & 32.2 & 36.8 & 35.4 & 36.6 & 35.6 & & 16.4 & 13.3 & \\
\hline & ... & ... & 52.6 & & & 42.0 & 51.0 & 59.7 & 57.8 & 60.6 & 59.9 & & 29.9 & 29.1 & \\
\hline government revenues & & $\ldots$ & 141.1 & & & 124.3 & 161.7 & 178.1 & 164.6 & 161.9 & 157.8 & & 71.2 & 56.2 & \\
\hline xports ratio (in percent) & 12.9 & 12.0 & 18.5 & & & 2.9 & 1.0 & 1.2 & 2.4 & 6.8 & 11.3 & & 1.4 & 1.6 & \\
\hline $\begin{array}{l}\text { PPG debt servi } \\
\text { PPG debt servi }\end{array}$ & 12.9 & 12.0 & 18.5 & & & 2.9 & 1.0 & 1.2 & 1.3 & 1.3 & 1.6 & & 1.4 & 1.6 & \\
\hline PPG debt service-to-revenue rati & $\begin{array}{r}57.2 \\
0155\end{array}$ & 39.9 & $\begin{array}{c}49.7 \\
10756\end{array}$ & & & $\begin{array}{r}8.5 \\
1887\end{array}$ & 3.3 & $\begin{array}{r}3.5 \\
15825\end{array}$ & 3.6 & 3.5 & $\begin{array}{l}4.1 \\
13096\end{array}$ & & 3.4 & 3.1 & \\
\hline $\begin{array}{l}\text { Total gross financing need (Millions of U.S. dollars) } \\
\text { Non-interest current account deficit that stabilizizs debt ratio }\end{array}$ & 215.5 & 609.4 & 1075.6 & & & 1884.7 & 1766.2 & $1582.5 \mathrm{l}$ & 1411.2 & 1021.2 & 1399.6 & & 812.4 & 6.8 & \\
\hline \multirow{2}{*}{\multicolumn{16}{|c|}{ Key macroeconomic assumptions }} \\
\hline & & & & & & & & & & & & & & & \\
\hline Real GDP growth (in percent & 6.3 & 6.2 & 2.8 & 3.5 & 4.6 & 5.4 & 7.0 & 6.8 & 8.1 & 6.7 & 7.0 & 6.8 & 4.7 & 4.4 & 4.7. \\
\hline & 7.0 & 8.9 & & & & 5.6 & 1.1 & 1.2 & 0.9 & 1.6 & & & 2.6 & & 2.6 \\
\hline & 3.0 & 2.9 & 2.6 & & .35 & $\begin{array}{r}3.4 \\
414\end{array}$ & 0.8 & 0.6 & 2.1 & 2.3 & 2.2 & 1.9 & 0.9 & 0.9 & 0.9. \\
\hline & 138.3 & $\begin{array}{r}8.7 \\
28.8\end{array}$ & -29.4 & $\begin{array}{l}22.9 \\
27.2\end{array}$ & 44.5 & ${ }_{40.4}^{41.4}$ & $\begin{array}{l}17.3 \\
153\end{array}$ & 5.5 & 8.5 & 6.7 & $\begin{array}{l}7.0 \\
54\end{array}$ & 14.4 & $\begin{array}{r}5.7 \\
152\end{array}$ & 5.0 & 5.5 \\
\hline $\begin{array}{l}\text { Growth of imports of Gis } \\
\text { Grant element of new pub }\end{array}$ & 83.7 & 28.8 & -23.6 & 27.2 & 27.3 & $\begin{array}{r}40.4 \\
8.8\end{array}$ & $\begin{array}{l}15.3 \\
22.8\end{array}$ & $\begin{array}{r}0.7 \\
27.2\end{array}$ & $\begin{array}{r}8.1 \\
28.9\end{array}$ & $\begin{array}{l}-1.4 \\
33.0\end{array}$ & $\begin{array}{r}5.4 \\
48.4\end{array}$ & $\begin{array}{l}11.4 \\
28.2\end{array}$ & $\begin{array}{l}15.2 \\
47.1\end{array}$ & $\begin{array}{r}4.4 \\
44.5\end{array}$ & $\begin{array}{r}5.2 \\
46.3\end{array}$ \\
\hline Government revenues (ex & 14.7 & & 17.1 & & & $\begin{array}{c}8.8 \\
19.6\end{array}$ & 19.9 & 20.7 & 21.5 & 22.6 & $\begin{array}{l}48.4 \\
22.6\end{array}$ & & & & $\begin{array}{l}46.3 \\
23.2\end{array}$ \\
\hline Millions of US dollars) $7 /$ & 429.4 & 359.5 & 874.4 & & & 1394.3 & 1891.0 & 1804.71 & 1587.9 & 1494.8 & 1540.7 & & & 1113.2 & \\
\hline & 225.6 & 267.5 & 764.6 & & & 1294.3 & 1303.6 & 1206.21 & 1049.6 & 951.9 & 974.8 & & 1008.8 & & \\
\hline $\mathrm{o} / \mathrm{s}$ & 203.8 & 92.0 & 109.8 & & & 100.0 & 587.4 & & 538.4 & 542.9 & 565.9 & & 591.3 & 496.2 & \\
\hline Grant-equivalent financing (in percent of $C$ & ... & ... & ... & & & 11.3 & 12.5 & 10.9 & 8.5 & 7.3 & 6.8 & & 4.9 & 1.6 & $\begin{array}{l}40.0 \\
4\end{array}$ \\
\hline Grant-equivalent financing (in percent of external financing) 8/ & $\cdots$ & $\ldots$ & $\cdots$ & & & 61.4 & 58.8 & 63.0 & 66.5 & 69.0 & 81.0 & & 80.4 & 75.2 & \\
\hline \\
\hline & 10028 & 11595 & 10958 & & & 12200 & 13193 & 14249 & 15539 & 16841 & 1829 & & 26530 & & \\
\hline & 13.7 & 15.6 & -5.5 & & & 11.3 & 8.1 & 8.0 & 9.1 & & & 3 & 7.5 & 7.1 & 7. \\
\hline lions of US dollars) & & & 2388.4 & & & 2806.4 & $4050.7:$ & 5070.95 & 5327.4 & 5971.6 & 6333.2 & & 4271.5 & 6893.4 & \\
\hline & & & & & & 3.8 & 10.2 & 7.7 & 1.8 & 4.1 & 2.1 & 5.0 & 1.1 & 0.3 & -0 . \\
\hline Gri & $\cdots$ & 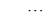 & & & & & & & & & & & & & \\
\hline & & $\cdots$ & 24.1 & & & 24.4 & 32.22 & 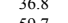 & 35.4 & 36.6 & 35.6 & & 16.4 & 13.3. & \\
\hline 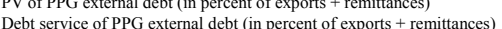 & $\cdots$ & $\cdots$ & $\begin{array}{l}52.6 \\
18.5\end{array}$ & & & $\begin{aligned} 42.0 \\
2.9\end{aligned}$ & $\begin{array}{c}51.0 \\
1.0\end{array}$ & $\begin{array}{cc}39.7 \\
12\end{array}$ & $\begin{array}{r}57.8 \\
1.3\end{array}$ & $\begin{array}{r}60.6 \\
13\end{array}$ & 59.9 & & 29.9 & 29.1 & \\
\hline Debt service of PTG external debt (in percent of exports + remm & $\cdots$ & $\cdots$ & 18.2 & & & 2.9 & 1.0 & 1.2 & 1.3 & 1.3 & 1.6 & & 1.4 & 1.6 & \\
\hline
\end{tabular}

Sources: Country authorities; and IMF staff estimates and projections.

$1 /$ Includes both public and private sector external debt.

$2 /$ Derived as $[\mathrm{r}-\mathrm{g}-?(1+\mathrm{g})](1+\mathrm{g}+\mathrm{q}+\mathrm{g}$ ?) times previous period debt ratio, with $\mathrm{r}=$ nominal interest rate; $\mathrm{g}=$ real GDP growth rate, and $\mathrm{l}=\mathrm{grow}$ h rate of GDP deflator in U.S. dollar terms.

i.c., changes in arrears and debt relieff; changes in gross foreign assets; and valuation adjustments. For projections also includes contribution from price and exchange rate changes.

6/ Historical averages and standard deviations are generally derived over the past 10 years, subject to data availability.

8/Grant-equivalent financing includes grants provided 
Table 2. Democratic Republic of the Congo: Sensitivity Analysis for Key Indicators of Public and Publicly Guaranteed External Debt, 2010-2030 (In percent)

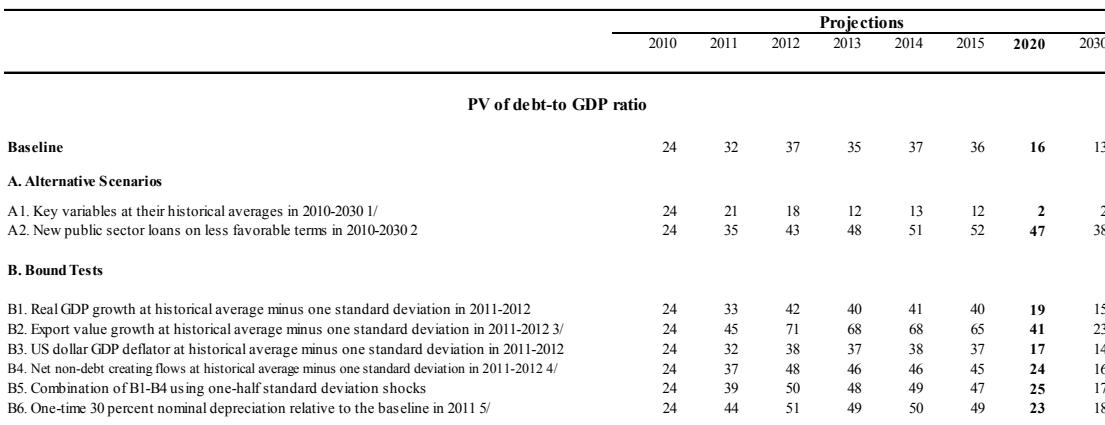

PV of de bt-to-exports ratio

Baseline

A. Alternative Scenarios

A1. Key variables at their historical averages in 2010-2030

A2 New public sector loans oncas as farers $2010-20302$

B. Bound Tests

B1. Real GDP growth at historical average minus one standard deviation in 2011-2012

B2. Export value growth at historical average minus one standard deviation in 2011-20123/

B3. US 10 .

B4. Net non-debt creating flows at historical average minus one standard deviation in 2011-20124

B5. Combination of B1-B4 using one-half standard devintion shocks

B6. One-time 30 percent nominal depreciation relative to the baseline in 20115 /

\section{PV of de bt-to-revenue ratio}

Baseline

A. Alternative Scenarios

A1. Key variables at their historical averages in 2010-2030

A2. New public sector loans on less favorable terms in 2010-2030

B. Bound Tests

B1. Real GDP growth at historical average minus one standard deviation in 2011-2012 B3. US dollar GDP deflator r t historical average minus one standard deviation in 2011-2012 at historical average minus one standard deviation in 2011-2012 B5. Combination of Bl-B4 using one-half standard deviation shocks

B6. One-time 30 percent nominal depreciation relative to the baseline in 20115 /

\section{Debt service-to-exports rati}

\section{Baseline}

A. Alternative Scenarios

A1. Key variables at their historical averages in 2010-2030

A2 New public sector loans on less favorable terms in $2010-20302$

B1. Real GDP growth at historical average minus one standard deviation in 2011-2012 B2. Export value growth at historical average minus one standard deviation in 2011-2012 $3 / 2$ B3. US dollar GDP deflator at historical average minus one standard deviation in 2011-20.12 B4. Net non-debt creating flows at historical average minus one standard deviation in 2011-2012 4 B5. Combination of B1-B4 using one-half standard deviation shocks

B6. One-time 30 percent nominal depreciation relative to the baseline in $20115 /$

Debt service-to-revenue ratio

Baseline

A. Alternative Scenarios

A1. Key variables at their historical averages in 2010-2030

2. New public sector loans on less favorable terms in 2010-2030

B1. Real GDP growth at historical average minus one standard deviation in 2011-2012

B.

B5. Combination of B1-B4 using one-half standard devintion shocks

B6. One-time 30 percent nominal depreciation relative to the baseline in 2011 5/

Memorandum item:

Grant element assumed on residual financing (ie, financing required above baseline)

Sources: Country authorities; and IMF staff estimates and projections.

1/ Variables include real GDP growth, growth of GDP deflator (in U.S. dollar terms), non-interest current account in percent of GDP, and non-debt creating flows.

$2 /$ Assumes that the interest rate on new borrowing is by 2 percentage points higher than in the baseline, while grace and maturity periods are the same as in the baseline

3/ Exports values are assumed to remain permanently at the lower level, but the current account as a share of GDP is assumed to return to its baseline level after the shock (implicitly assumins

an offsetting adjustment in import levels).

4/ Includes official and private transfers and FDI

5/ Depreciation is defined as percentage decline in dollar/local currency rate, such that it never exceeds 100 percent.

6/ Applies to all stress scenarios except for A2 (less favorable financing) in which the terms on all new financing are as specified in footnote 2

CInternational Monetary Fund. Not for Redistribution 
Table 3. Democratic Republic of the Congo: Public Sector Debt Sustainability Framework, Baseline Scenario, 2007-30

\begin{tabular}{|c|c|c|c|c|c|c|c|c|c|c|c|c|c|c|c|}
\hline & \multicolumn{3}{|c|}{ Actual } & \multirow[b]{2}{*}{ Average } & \multirow[b]{2}{*}{$\begin{array}{l}\text { Standard } \\
\text { Deviation }\end{array}$} & \multicolumn{4}{|l|}{ Estimate } & \multicolumn{6}{|c|}{ Projections } \\
\hline & 2007 & 2008 & 2009 & & & 2010 & 2011 & 2012 & 2013 & 2014 & 2015 & $\begin{array}{l}2010-15 \\
\text { Average }\end{array}$ & 2020 & & $\begin{array}{l}2016-30 \\
\text { Average }\end{array}$ \\
\hline $\begin{array}{l}\text { Public sector debt } 1 / \\
\text { o/w foreign-currency denominated }\end{array}$ & $\begin{array}{l}125.9 \\
125.7\end{array}$ & $\begin{array}{l}145.0 \\
132.5\end{array}$ & $\begin{array}{l}34.3 \\
21.1\end{array}$ & & & $\begin{array}{l}36.0 \\
25.5\end{array}$ & $\begin{array}{l}41.1 \\
35.0\end{array}$ & $\begin{array}{l}43.9 \\
41.1\end{array}$ & $\begin{array}{l}43.6 \\
43.6\end{array}$ & $\begin{array}{l}45.2 \\
45.2\end{array}$ & $\begin{array}{l}44.7 \\
44.7\end{array}$ & & $\begin{array}{l}26.5 \\
26.5\end{array}$ & $\begin{array}{l}20.6 \\
20.6\end{array}$ & \\
\hline Change in public sector debt & -23.3 & 19.1 & -110.7 & & & 1.6 & 5.2 & 2.8 & -0.3 & 1.6 & -0.5 & & -0.2 & -1.0 & \\
\hline Identified debt-creating flows & -31.5 & 0.8 & -1.0 & & & -3.7 & 4.6 & 2.4 & 0.8 & 0.0 & -1.7 & & -0.5 & -0.5 & \\
\hline Primary deficit & -1.7 & -1.0 & -0.2 & 1.6 & 2.9 & 3.3 & 8.5 & 6.1 & 4.4 & 3.3 & 1.7 & 4.5 & 1.2 & 0.7 & 0.7 \\
\hline Revenue and grants & 17.0 & 20.8 & 24.0 & & & 30.4 & 30.1 & 29.4 & 28.5 & 28.5 & 28.7 & & 27.5 & 25.3 & \\
\hline of which: grants & 2.2 & 2.3 & 7.0 & & & 10.6 & 9.9 & 8.5 & 6.8 & 5.7 & 5.3 & & 3.8 & 1.2 & \\
\hline Primary (noninterest) expenditure & 15.2 & 19.8 & 23.9 & & & 33.7 & 38.6 & 35.5 & 33.0 & 31.8 & 30.4 & & 28.7 & 26.0 & \\
\hline Automatic debt dynamics & -26.6 & 4.5 & 4.1 & & & -5.4 & -3.8 & -3.7 & -3.6 & -3.2 & -3.5 & & -1.6 & -1.3 & \\
\hline Contribution from interest rate/growth differential & -14.1 & -13.9 & 7.9 & & & -4.6 & -3.5 & -3.3 & -3.6 & -3.2 & -3.4 & & -1.6 & -1.3 & \\
\hline of which: contribution from averager & -5.3 & -6.6 & 11.9 & & & -2.9 & -1.2 & -0.7 & -0.3 & -0.4 & -0.4 & & -0.4 & -0.3 & \\
\hline of which: contribution from real GDP grow & -8.8 & -7.3 & -4.0 & & & -1.8 & -2.3 & -2.6 & -3.3 & -2.7 & -3.0 & & -1.2 & -0.9 & \\
\hline Contribution from real exchange rate depreciat & -12.6 & 18.4 & -3.8 & & & -0.8 & -0.3 & -0.4 & 0.0 & -0.1 & -0.1 & & . & $\ldots$ & \\
\hline Other identified debt-creating flows & -3.1 & -2.7 & -4.9 & & & -1.5 & 0.0 & 0.0 & 0.0 & 0.0 & 0.0 & & 0.0 & 0.0 & \\
\hline Privatization receipts (negative) & 0.0 & 0.0 & 0.0 & & & 0.0 & 0.0 & 0.0 & 0.0 & 0.0 & 0.0 & & 0.0 & 0.0 & \\
\hline Recognition of implicit or contingent liabilities & 0.0 & 0.0 & 0.0 & & & 0.0 & 0.0 & 0.0 & 0.0 & 0.0 & 0.0 & & 0.0 & 0.0 & \\
\hline Debt relief(HIPC and other) & -3.1 & -2.7 & -4.9 & & & -1.5 & 0.0 & 0.0 & 0.0 & 0.0 & 0.0 & & 0.0 & 0.0 & \\
\hline Other (specify, e.g. bank recapitalization) & 0.0 & 0.0 & 0.0 & & & 0.0 & 0.0 & 0.0 & 0.0 & 0.0 & 0.0 & & 0.0 & 0.0 & \\
\hline Residual, including asset changes & 8.2 & 18.3 & -109.7 & & & 5.3 & 0.5 & 0.4 & -1.2 & 1.6 & 1.2 & & 0.3 & -0.5 & \\
\hline \multicolumn{16}{|l|}{ Other Sustainability Indicators } \\
\hline PV of public sector debt & 0.2 & 12.5 & 37.3 & & & 34.9 & 38.3 & 39.6 & 35.4 & 36.6 & 35.6 & & 16.4 & 13.3 & \\
\hline $\mathrm{o} / \mathrm{w}$ foreign-currency denominated & 0.0 & 0.0 & 24.1 & & & 24.4 & 32.2 & 36.8 & 35.4 & 36.6 & 35.6 & & 16.4 & 13.3 & \\
\hline $\mathrm{o} / \mathrm{w}$ external & $\ldots$ & $\ldots$ & 24.1 & & & 24.4 & 32.2 & 36.8 & 35.4 & 36.6 & 35.6 & & 16.4 & 13.3 & \\
\hline PV of contingent liabilities (not included in public sector debt) & $\cdots$ & $\cdots$ & & & & & & & & & & & & & \\
\hline Gross financing need $2 /$ & 6.7 & 6.4 & 8.3 & & & 5.0 & 9.1 & 6.8 & 5.2 & 4.1 & 2.7 & & 1.9 & 1.5 & \\
\hline $\mathrm{PV}$ of public sector debt-to-revenue and grants ratio (in percent) & 1.4 & 60.4 & 155.0 & & & 114.5 & 127.1 & 134.7 & 124.2 & 128.3 & 124.2 & & 59.7 & 52.5 & \\
\hline $\mathrm{PV}$ of public sector debt-to-revenue ratio (in percent) & 1.6 & 68.0 & 218.3 & & & 175.7 & 189.1 & 189.0 & 162.7 & 160.1 & 152.5 & & 69.2 & 55.1 & \\
\hline o/w external $3 /$ & & & 141.1 & & & 123.0 & 158.8 & 175.5 & 162.7 & 160.1 & 152.5 & & 69.2 & 55.1 & \\
\hline Debt service-to-revenue and grants ratio (in percent) $4 /$ & 49.6 & 35.5 & 35.3 & & & 5.5 & 2.2 & 2.4 & 2.7 & 2.8 & 3.2 & & 2.8 & 2.9 & \\
\hline Debt service-to-revenue ratio (in percent) $4 /$ & 57.2 & 39.9 & 49.7 & & & 8.4 & 3.3 & 3.4 & 3.6 & 3.5 & 4.0 & & 3.3 & 3.0 & \\
\hline Primary deficit that stabilizes the debt-to-GDP ratio & 21.6 & -20.1 & 110.5 & & & 1.7 & 3.3 & 3.3 & 4.8 & 1.7 & 2.3 & & 1.3 & 1.8 & \\
\hline \multicolumn{16}{|l|}{ Key macroeconomic and fiscal assumptions } \\
\hline Real GDP growth (in percent) & 6.3 & 6.2 & 2.8 & 3.5 & 4.6 & 5.4 & 7.0 & 6.8 & 8.1 & 6.7 & 7.0 & 6.8 & 4.7 & 4.4 & 4.7. \\
\hline Average nominal interest rate on forex debt (in percent) & 3.0 & 2.9 & 2.6 & 1.7 & 1.3 & 3.4 & 0.8 & 0.6 & 0.6 & 0.5 & 0.5 & 1.1 & 0.9 & 0.9 & 0.8 \\
\hline Average real interest rate on domestic debt (in percent) & & & & $\ldots$ & & & $\ldots$ & ... & ... & ... & $\ldots$ & & ... & ... & .. \\
\hline Real exchange rate depreciation (in percent,, indicates depreciatior & -9.3 & 16.5 & -2.6 & -4.1 & 19.9 & -4.0 & ... & ... & ... & $\ldots$ & $\ldots$ & & & & \\
\hline Inflation rate (GDP deflator, in percent) & 17.9 & 18.9 & 33.3 & 105.7 & 184.1 & 24.3 & 12.6 & 9.7 & 8.0 & 8.5 & 7.9 & 11.8 & 6.7 & 6.7 & 6.9 \\
\hline Growth of $\mathrm{r}$ & -0.1 & 0.4 & 0.2 & 0.2 & 0.2 & 0.5 & 0.2 & 0.0 & 0.0 & 0.0 & 0.0 & 0.1 & 0.0 & 0.0 & 0.0 \\
\hline Grant element of new external borrowing & & $\ldots$ & $\ldots$ & & & 8.8 & 22.8 & 27.2 & 28.9 & 33.0 & 48.4 & 28.2 & 47.1 & 44.5 & ... \\
\hline
\end{tabular}

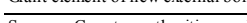

$2 /$ Gross financing need is defined as the primary deficit plus debt service plus the stock of short-term debt at the end of the last period

$3 /$ Revenues excluding grants.

4/ Debt service is defined as the sum of interest and amortization of medium and long-term debt.

$5 /$ Historical averages and standard deviations are generally derived over the past 10 years, subject to data availability. 
Table 4. Democratic Republic of the Congo: Sensitivity Analysis for Key Indicators of Public Debt 2010-30

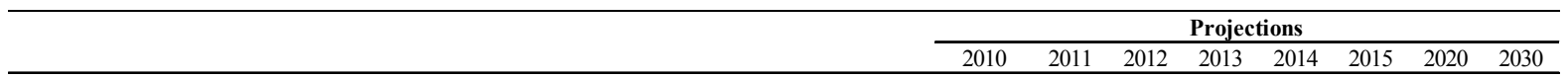

\section{PV of Debt-to-GDP Ratio}

Baseline

$\begin{array}{rrrrrrrr}35 & 38 & 40 & 35 & 37 & 36 & 16 & 13 \\ & & & & & & & \\ 35 & 32 & 30 & 24 & 25 & 25 & 0 & 0 \\ 35 & 33 & 32 & 27 & 28 & 29 & 22 & 41 \\ 35 & 39 & 41 & 38 & 40 & 40 & 30 & 62\end{array}$

A1. Real GDP growth and primary balance are at historical averages

A2. Primary balance is unchanged from 2010

A3. Permanently lower GDP growth 1/

(1)

\section{B. Bound tests}

B1. Real GDP growth is at historical average minus one standard deviations in 2011-2012

B2. Primary balance is at historical average minus one standard deviations in 2011-2012

$\begin{array}{llllllll}35 & 43 & 51 & 50 & 55 & 57 & 51 & 75 \\ 35 & 34 & 34 & 30 & 32 & 31 & 12 & 10 \\ 35 & 35 & 35 & 33 & 37 & 39 & 30 & 48 \\ 35 & 49 & 49 & 42 & 43 & 42 & 22 & 19 \\ 35 & 48 & 49 & 45 & 45 & 44 & 24 & 19\end{array}$

B4. One-time 30 percent real depreciation in 2011

B5. 10 percent of GDP increase in other debt-creating flows in 2011

PV of Debt-to-Revenue Ratio 2/

\section{Bas eline}

A1. Real GDP growth and primary balance are at historical averages

A2. Primary balance is unchanged from 2010

A3. Permanently lower GDP growth 1/

$\begin{array}{llllllll}115 & 129 & 138 & 131 & 139 & 140 & 107 & 242\end{array}$

\section{B. Bound tests}

B1. Real GDP growth is at historical average minus one standard deviations in 2011-2012

B2. Primary balance is at historical average minus one standard deviations in 2011-2012

B3. Combination of B1-B2 using one half standard deviation shocks

B4. One-time 30 percent real depreciation in 2011

B5. 10 percent of GDP increase in other debt-creating flows in 2011

$\begin{array}{rrrrrrrr}115 & 139 & 167 & 169 & 186 & 193 & 180 & 293 \\ 115 & 114 & 116 & 106 & 111 & 108 & 45 & 41 \\ 115 & 113 & 114 & 112 & 127 & 132 & 108 & 189 \\ 115 & 161 & 165 & 148 & 151 & 146 & 78 & 74 \\ 115 & 160 & 167 & 156 & 159 & 154 & 85 & 74\end{array}$

\section{Debt Service-to-Revenue Ratio 2/}

\section{Baseline}

\section{A. Alternative scenarios}

A1. Real GDP growth and primary balance are at historical averages

A2. Primary balance is unchanged from 2010

A3. Permanently lower GDP growth $1 /$

$\begin{array}{rrrrrrrr}5 & 2 & 2 & 1 & 1 & 1 & 0 & 0 \\ 5 & 2 & 2 & 2 & 2 & 2 & 3 & 8 \\ 5 & 2 & 2 & 3 & 3 & 4 & 4 & 12\end{array}$

\section{B. Bound tests}

B1. Real GDP growth is at historical average minus one standard deviations in 2011-2012

B2. Primary balance is at historical average minus one standard deviations in 2011-2012

B3. Combination of B1-B2 using one half standard deviation shocks

B4. One-time 30 percent real depreciation in 2011

B5. 10 percent of GDP increase in other debt-creating flows in 2011

$\begin{array}{rrrrrrrr}5 & 2 & 3 & 4 & 4 & 5 & 7 & 17 \\ 5 & 2 & 2 & 2 & 2 & 3 & 2 & 2 \\ 5 & 2 & 2 & 2 & 2 & 3 & 4 & 10 \\ 5 & 3 & 4 & 4 & 4 & 5 & 5 & 6 \\ 5 & 2 & 4 & 4 & 4 & 4 & 4 & 5\end{array}$

Sources: Country authorities; and IMF staff estimates and projections.

1/ Assumes that real GDP growth is at baseline minus one standard deviation divided by the square root of the length of the projection period.

2/ Revenues are defined inclusive of grants. 